Florida International University FIU Digital Commons

7-23-2003

\title{
An incident at sea: The historic combat between U.S. Navy Blimp K-74 and U-Boat 134
}

Anthony Atwood

Florida International University, Anthony.Atwood@fiu.edu

DOI: $10.25148 /$ etd.FI08081502

Follow this and additional works at: https://digitalcommons.fiu.edu/etd

\section{Recommended Citation}

Atwood, Anthony, "An incident at sea: The historic combat between U.S. Navy Blimp K-74 and U-Boat 134" (2003). FIU Electronic Theses and Dissertations. 12.

https://digitalcommons.fiu.edu/etd/12

This work is brought to you for free and open access by the University Graduate School at FIU Digital Commons. It has been accepted for inclusion in FIU Electronic Theses and Dissertations by an authorized administrator of FIU Digital Commons. For more information, please contact dcc@fiu.edu. 
FLORIDA INTERNATIONAL UNIVERSITY

Miami, Florida

AN INCIDENT AT SEA:

THE HISTORIC COMBAT BETWEEN

U.S. NAVY BLIMP K-74 AND U-BOAT 134

\author{
A thesis submitted in partial fulfillment of the \\ requirements for the degree of \\ MASTER OF ARTS \\ in \\ HISTORY \\ by
}

Anthony Dewey Atwood

2003 
To: Dean Arthur W. Herriott

College of Arts and Sciences

This thesis, written by Anthony Dewey Atwood, and entitled: An Incident at Sea: The Historic Combat between U.S. Navy Blimp K-74 and U-boat 134, having been approved in respect to style and intellectual content, is referred to you for judgment.

We have read this thesis and recommend that it be approved.

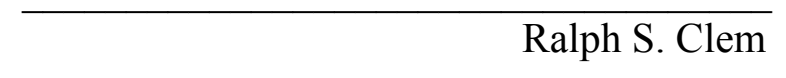

William O. Walker III

Darden A. Pyron, Major Professor

Date of Defense: July 23, 2003

The thesis of Anthony Dewey Atwood is approved.

Dean Arthur W. Herriott
College of Arts and Sciences

Florida International University, 2003 


\section{ACKNOWLEDGMENTS}

I wish to gratefully acknowledge the kind assistance of Lothar E. Zeidler, Ph.D., Professor Emeritus of the Linguistics Department at Rutgers University for his invaluable help in translating the radio transmissions of the U-134. His encouragement was important to this work. Equally important to this work have been the K-74 survivors Nelson G. Grills, Robert Herbert Bourne, John Schmidt and John F. Rice. Likewise the scholarly help of Professor Michael Gannon, Professor Gwyn Davies, Al Cope, Richard Collins, Max May, Peter W. Soverel, Tim Nininger of the National Archives, and my thesis committee-members, Professors Darden A. Pyron, William O. Walker III and Ralph Clem were vital. This work could not have been done without the help of German U-boat historians Professor Doctor Jurgen Rohwer, Horst Bredow and Franz Selinger. 
ABSTRACT OF THE THESIS

AN INCIDENT AT SEA:

THE HISTORIC COMBAT BETWEEN U.S. NAVY BLIMP K-74

AND U-BOAT 134

by

Anthony Dewey Atwood

Florida International University, 2004

Miami, Florida

Professor Darden A. Pyron, Major Professor

This thesis studies the historic encounter between United States Navy airship K74 and Nazi submarine U-134 in World War II.

The Battle of the Atlantic is examined through case study of this one U-boat and its voyage. In all things except her fight with the American blimp, the patrol was perfectly typical. Looked at from start to finish, both her reports and the reports of the Allies encountered, many realities of the war can be studied.

U-134 sailed to attack shipping between Florida and Cuba. She was challenged by the attack of United States Navy airship K-74 over the Florida Straits. It is the only documented instance of battle between two such combatants in history. That merits attention.

Thesis finding disprove historian William Eliot Morison's contention that the K74 airship bombs were not dropped and did not damage the U-boat Study of this U-boat and its antagonist broadens our understanding of the Battle of the Atlantic. It is a contribution to our knowledge of military, naval, aviation, and local history. 


\section{TABLE OF CONTENTS}

CHAPTER

PAGE

I. INTRODUCTION AND REVIEW OF THE LITERATURE ............................. 1

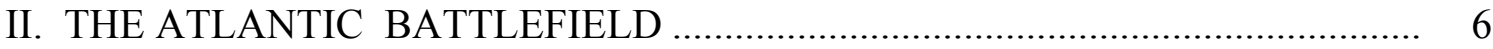

The German Navy/U-boat Successes........................................................... 7

German Command/Surface Fleet Defeats ................................................... 10

Supply Ships and Raiders .................................................................. 12

The Panay Incident ..................................................................... 14

The Atlantic Neutrality Patrol................................................................... 16

Ships for Bases/ABC Talks/Lend Lease .................................................... 17

The Navy Armed Guard/First Attacks ....................................................... 22

The Hooligan Navy/The Civil Air Patrol..................................................... 28

Queen ships/Milk Cows/Wizard War ......................................................... 30

Enter the Blimps .................................................................................. 36

III. THE PATROL OF THE U-134 .................................................................. 39

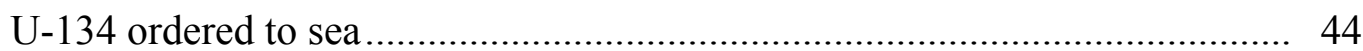

Heading - outbound ......................................................................... 46

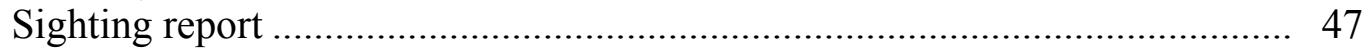

Communications signal................................................................. 47

Refueling operations in mid-Atlantic.................................................... 48

Heading - to combat zone..................................................................... 51

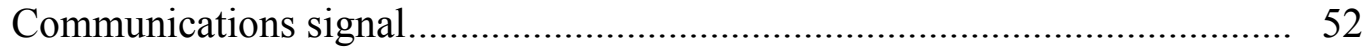

Orders to attack Florida and Cuba ...................................................... 52

Action report: combat against Seaplane ................................................. 53

Action report: combat off the Isle of Pines ............................................... 56

IV. BATTLE AGAINST NAVY BLIMP K-74 _............................................ 57

V. RETREAT FROM BATTLE ............................................................... 84

Action report: combat against Key West Bomber ..................................... 84

Damage report.......................................................................... 86

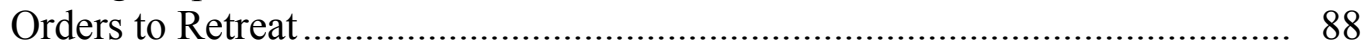

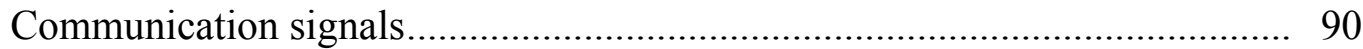

Directions for escape via Spain............................................................. 93

Action report: combat against a Carrier................................................. 95

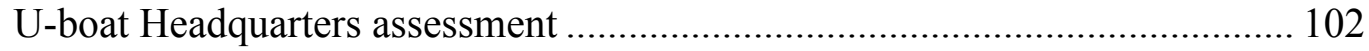

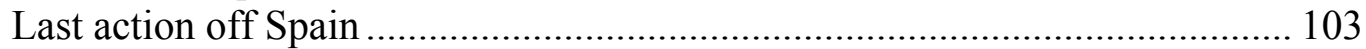

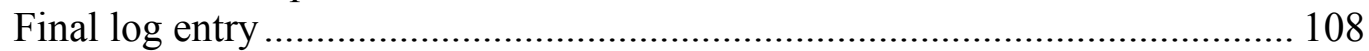

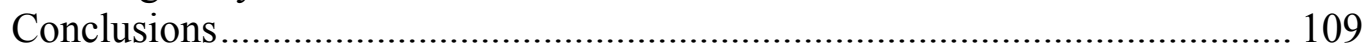

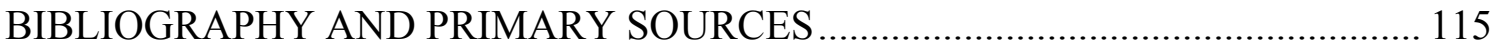

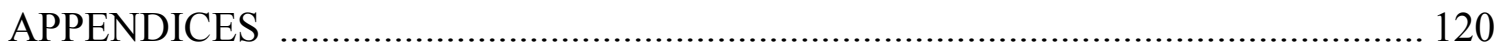




\section{CHAPTER I. INTRODUCTION AND REVIEW OF THE LITERATURE}

The Battle of the Atlantic (September 1939-May 1945) was the defining naval contest of modern times. The German Reich sought to overthrow the existing AngloFranco-American global hegemony and replace it with a German world empire. Supremacy over civilization and its produce was the aim of the charismatic Adolf Hitler and under his leadership Germany nearly succeeded in this. The regime crushed Continental opposition and united most of Europe under his new world order. The German challenge to the British Empire and the nascent world-power of the United States was met and fought out on, under, and over the Atlantic Ocean.

The Nazi attempt initially focused on a naval blockade of the British Isles. Britain fought to keep her sea lanes open to help from her global commonwealth and escalating United States support. With the German invasion of Russia, combat and naval operations grew exponentially. The entrance of the United States as a belligerent into the war in December 1941 made America the center of re-supply for the Allies. In addition to keeping Britain and Russia supplied to continue fighting, a second war aim of the United States emerged as the movement of vast armed forces to the overseas fronts for the eventual invasion of Europe to defeat the Axis powers. Maritime traffic across the Atlantic Ocean was the only means to make this happen.

American entry into the war was precipitated by the surprise attack by Japan on our Pacific base at Pearl Harbor on December 7, 1941. But despite terrible United States setbacks in the Pacific, the crux of the situation for ultimate world victory was control of the Atlantic and the defeat of Germany. The Allied decision to concentrate naval and military power on keeping the Atlantic Ocean free was critical to victory. 
Against this naval operation the Nazis interposed a variety of forces including capital ships, e-boats, the mining of critical channels, and luftwaffe attacks on shipping around the British Isles and especially the Arctic waters around Russia. But their primary weapon to interdict and stop Allied shipping was the U-boat. The Atlantic was the seat of war. It was a battle of geography against the natural elements, of technology and of pitted antagonists: submarines versus the combination of every surface and air force and any invention and primitive device that would stop them. These conditions are examined through the prism of one U-boat on a single patrol in the middle of the war. In all things except one -- her fight with an American blimp, this voyage was singularly typical. In large part this study will be through the submarine's own messages. This perspective from the "other side of the hill" broadens our understanding of these events.

U-134 sailed from France on June 7, 1943, her mission was to attack shipping between Florida and Cuba. During her voyage the scales of war tipped in the struggle at sea. She encountered as routine many of the critical aspects of the war at sea. In all matters her voyage was a representative experience of the Battle of the Atlantic in general. In her encounter with United States Airship K-74, history was made.

\section{A Review of the Literature}

Historians have produced little concerning the U-134 and its combat against the K-74. The cornerstone document in writing is that of naval historian and Rear Admiral Samuel Eliot Morison, USNR. His account is contained in his 15-volume History of U.S. Naval Operations in World War II. ${ }^{1}$ Morison devotes a paragraph and a footnote to the event in Volume Two of his series. The account is flawed by the inaccurate report that

\footnotetext{
${ }^{1}$ Morison, History of United States Naval Operations in World War II, Vol. II, p. 194.
} 
no bombs were released by the K-74 airship. This would be trivial, but that it concerns the life and death activity of combat. Debate over the combat proficiency of the K-74 and its crew are examined in-depth in Chapter Four of this thesis.

In $1986 \underline{\text { Kite Balloons to Airships }},{ }^{2}$ Volume Four of the official $75^{\text {th }}$ anniversary commemorative publication of naval aviation repeated this report.

Gordon Vaeth's book Blimps and U-boats ${ }^{3}$ provides a longer, similar account. William F. Althoff's $\underline{S k y ~ S h i p s}^{4}$ gives a paragraph on the encounter, as do U.S. Navy $\underline{\text { Pressure Airships }}^{5}$ by James R. Shock, Airships in Peace and War ${ }^{6}$ by Robert Jackson, $\underline{\text { Lighter than Air }}^{7}$ by Lee Payne, and Airships of the Future ${ }^{8}$ by William J. White.

"Death of a Sub-Killer,"9 an article in Family Weekly, November 1961, gives a dramatic version of the encounter. Two articles by this thesis writer have been published, in the Miami Herald, March 1997, ${ }^{10}$ and Naval Aviation News, April 1998. ${ }^{11}$ Like the others mentioned above, these all repeated the error no bombs dropped.

Research proves that both the German reports and the United States Board for the Correction of Naval Records (BCNR) of 1960 clearly refute the error. Its persistence in military lore is an example of how the erroneous through repetition gains currency as history. This historic event is studied thoroughly in Chapter Four of the thesis.

\footnotetext{
${ }^{2}$ Kite Balloons to Airships, Vol. Four, p. 52.

${ }^{3}$ Vaeth, Blimps and U-boats, p. 73-82.

${ }^{4}$ Althoff, Sky Ships, p. 192.

${ }^{5}$ Shock, U.S. Navy Pressure Airships, Vol. II, p. 20-21.

${ }^{6}$ Jackson, Airships in War and Peace, p. 198.

${ }^{7}$ Payne, Lighter than Air, p. 239.

${ }^{8}$ White, Airships of the Future, p. 73.

${ }^{9}$ Liberman, "Death of a Sub-Killer," Family Weekly Magazine, November 26, 1961.

${ }^{10}$ Atwood, "Blimpie and the Sub," Tropic Magazine, Miami Herald, March 9, 1997.

${ }^{11}$ Atwood, "Battle Between the Blimp and the Sub," Naval Aviation News, March-April 1997.
} 
An account of the combat mixing dates, participants and events, appears in $\underline{\mathrm{U}}$ boats of the Caribbean ${ }^{12}$ by Gaylord T. M. Kelshall. This version repeats the usual bombs-failed-to-drop report, adding a bomber attack on the U-boat the same night, with the bomber being shot down. In addition, it throws in an engagement against a PV-1 Ventura as inaccurately also occurring this same night. This version is found nowhere else in the literature, and this author can find no substantiation in the official records.

An article by Richard Collins in the September 1994 issue of Aviation History ${ }^{13}$ provides information on the U-boat 134 . The article looks only in passing at the combat between the K-74 blimp, and repeats the usual "no bombs were dropped" theory. But it is the only writing found with a focus on the submarine and its fateful patrol. Written by a former American submariner, it contains useful insight and information on the other encounters of the U-134. The U-boat catalogs of Kenneth Wynn: U-boat Operations of the Second World War, ${ }^{14}$ and Clay Blair: Hitler's U-boat War ${ }^{15}$ offer brief careers of the U-boat. Both repeat Morison's conclusions. Blair mentions the award in 1997 of the posthumous Purple Heart and Commendation Medal to the surviving family members of the K-74 bombardier, Isadore Stessel. Mention of the U-134 can be found in $\underline{\mathrm{U}-b o a t s}$ Destroyed, German Submarine Losses in the World Wars ${ }^{16}$ by Paul Kemp. Search, Find and Kill, ${ }^{17}$ by Norman Franks gives an account of the Royal Air Force Patrol of August 24, 1943. So does Royal Canadian Air Force at War, 1939-1945. ${ }^{18}$

\footnotetext{
${ }^{12}$ Kenshall, U-boats of the Caribbean, p. 342.

${ }^{13}$ Collins, "Last Patrol of U-134," Aviation History, September 1994.

${ }^{14} \mathrm{Wynn}_{2}$ U-boat Operations of the Second World War, Vol. One, p. 109-110.

${ }^{15}$ Blair, Hitler's U-boat War, The Hunted, Vol. Two, p. 384-395.

${ }^{16} \mathrm{Kemp}$, U-boats Destroyed, German Submarine Losses in the World Wars, p. 143.

${ }^{17}$ Franks, Search, Find and Kill, p. 233.

${ }^{18}$ Milberry, Royal Canadian Air Force at War, 1939-1945, p. 350.
} 
The New York Daily Mirror ${ }^{19}$ newspaper of July 31, 1943 contains front page and inside page articles on the combat. The UP wire service account is both colorful and vague on specifics of when, where and who participated. Nonetheless there is useful obituary information on the bombardier, who was a native New Yorker. This connection may explain how the newspaper got the story past the censors. (See Appendix page 126).

A remarkable article concerning the K-74/U-134 encounter appeared in the January 1958 issue of the Naval Institute Proceedings. ${ }^{20}$ The brief article submitted by U-boat veteran Herr Franz Sellinger includes two photographs purported to be of the combat, taken by the submarine. One picture is a grainy depiction of what is captioned the K-74 crashed upon the surface of the ocean. The other photo appears to have been taken from a submarine conning tower. It shows U-boat crewmen hauling aboard a piece of canvas-like fabric. The claim of the 1958 article is that the U-134 photographed the blimp after it crashed and then pulled aboard a section of blimp fabric for a trophy. This hoax is addressed definitively in the thesis conclusion. (See Appendices page 126).

The primary sources listed in the Bibliography provide a compilation of the retrievable official documentation, Allied and German, pertaining to the subject. This thesis, drawn from them, is by far the longest and most detailed study of the voyage of the U-134 and its combat with United States Navy airship K-74 to date. An analysis of the author's findings, vis a vis those of Morrison, Vaeth, Wynn, Blair and the rest follows in Chapter Four.

\footnotetext{
${ }^{19}$ Daily Mirror, July 31, 1943.

${ }^{20}$ Selinger, Proceedings, January 1958, p. 96.
} 


\section{CHAPTER II. THE ATLANTIC AS BATTLEFIELD}

That the Battle of the Atlantic began at Pearl Harbor is only to state cause and effect. Within days of that attack the German and Italian regimes closed ranks with their Japanese ally. December $11^{\text {th }}$ the Reichstag approved their Fuhrer's demand for war. Italy soon followed. ${ }^{21}$ The fight was not long in reaching our shores. But long before the bombs rocked Pearl Harbor, the stage had been set. The Atlantic was already an armed camp and a battlefield.

The naked eye can see about seventeen miles. At sea that seventeen miles of sight is 360 degrees, in every direction. The area that encompasses eyesight is large enough to hide a dozen Gettysburg-size areas. Next consider the distance, for example, between the Panama Canal and England: it is 4,580 nautical miles. How many Gettysburgs will the ocean hold, end to end in every direction? The size of the Atlantic is simply stupendous. To prosecute military operations over, under and upon the vast trackless expanse of the sea is an amazing feat.

Any study of the Battle of the Atlantic must of necessity be a study of communications and technology. This thesis reviews these, and examines the combat experience at sea. The study will be through the prism of the experiences of a single patrol of a single warship on the watery battlefield.

Hostile naval operations between Germany and Great Britain raged since the war broke out over Poland on September 1, 1939. Britain was a maritime power connected to its overseas dominions by the oceans and its navy. Canada, Bermuda, Jamaica, Trinidad, Sierra Leone, Nigeria and South Africa were her bases of Atlantic support. The sea roads

\footnotetext{
${ }^{21}$ Salmaggi and Pallavisini, 2194 Days of War, p. 192.
} 
from the Atlantic east via The Cape of Good Hope, or west around Cape Horn led to her great sustaining empire of the Indian subcontinent, Malaya, Australia and New Zealand. Any passage using the short cut of the Suez Canal had first to pass their citadel at the Straits of Gibraltar.

The object of the German Third Reich was to replace the British Empire as the predominant power. Its naval strategy was to achieve this by disconnecting Britain from its commonwealth of nations, closing Britain's sea-lanes. The tactical means was their submarine arm: the U-boat.

\section{The German Navy}

The modern German navy began with Wilhelm II of the Second Reich. In the empire building of the late 19th century the Kaiser planned a world-class navy. One purpose was to connect their expanding empire overseas. Equally, the vanity of monarchs fueled this competition with their cousins, the royal family of Britain. ${ }^{22}$

Germany embarked on a vast national program to build such a fleet. This and the other competitions of these empires inevitably collided in the First World War. Great Britain and her continental partner the, French Republic, were sustained by the resources of their overseas possessions. The British home fleet of dreadnaughts blockaded continental Germany from access to this strength. It was the same strategy of blockade as was used against Napoleon.

The great German attempt to seize control of the Atlantic by set piece battle was their sortie into the North Sea of 1916. Their battleship fleet got as far as Jutland, where the Royal Navy met them head on. The German fleet was decisively turned back.

\footnotetext{
${ }^{22}$ Howarth, The Dreadnoughts, p. 11.
} 
The fate of the German surface navy at the close of World War One was dismal. After the Armistice in 1918 the fleet steamed into captivity at the British anchorage of Scapa Flow in the Orkneys north of Scotland. The crews were interned as prisoners aboard their own ships. Most were then repatriated. On June 21, 1919 prearranged signals were exchanged among the skeleton crews remaining aboard. These Germans opened the drain cocks of their own ships and scuttled them. At the end of the day, 51 German warships, totaling nearly 500,000 tons lay on the bottom. ${ }^{23}$

Germany's chance for mastery of the ocean was in their submarines. The submarine was a weapon capable of separating the British Isles from their overseas strength. The U-boat was small and nondescript. Its methods of stealth, secrecy and surprise were not the attributes of the established paradigm for champions. Their special opponents were the plebian, ungainly and weak merchant vessels of the world. U-boat warfare was neither glamorous nor chivalrous. But the U-boat possessed one virtue allimportant in war: the weapon worked. The U-boat service of World War One was the success story of the German Navy. It inflicted tangible damage on the western allies, sinking nearly 5,000 ships, totaling a colossal 11 million tons of shipping. The U-boats took the fight to the enemy, doing their best to blockade the British Isles. Their work denied troops, munitions and supplies to the Western Front. It helped the German army in its terrible land battle.

In 1935, German Chancellor Hitler repudiated the Versailles Treaty. In the years of rearmament that followed, support for rebuilding of the big dreadnaughts was modest. Adolf Hitler was himself a former army corporal, a decorated frontsoldat. He lacked

\footnotetext{
${ }^{23}$ The Dreadnoughts, pp. 166-168.
} 
interest in the navy and in the U-boat service. But the German people respected them and the new German shipbuilding program included U-boats. By the end of 1935, Germany launched fourteen. By the summer of 1939 the U-boat flotilla had expanded to 57 attack boats. During the war Germany built over a thousand more.

\section{$\underline{\text { U-Boat Successes }}$}

When hostilities broke out in August 1939, the U-boats struck out for the sea. The Unterseeboote stood out in filling the Reich's naval ambition. Off Ireland on September 17 the $U-29$ sent a pair of torpedoes into the British aircraft carrier HMS Courageous. The carrier sank rapidly, with 518 crewmen lost, including its captain. ${ }^{24} \mathrm{~A}$ month later another U-boat outdid even this stunning victory. October 14, the U-47 made its way to the British Navy anchorage of Scapa Flow. The U-boat penetrated into the heart of the bay. Leutnant Gunther Prien and his U-47 sent torpedoes into the moored and unsuspecting battleship HMS Royal Oak. Royal Oak appeared slow going down as U-47 cleared the area. U-47 returned and shot another brace of torpedoes into her. The second attack finished Royal Oak. She heeled and sank. For good measure U-47 then torpedoed the cruiser HMS Repulse, damaging her severely. 786 British sailors died in the attack. ${ }^{25}$ Prien and his crew returned to a hero's welcome in Germany. The public lavished parades, publicity and affection on them. Hitler presided over ceremonies decorating the sailors. The loss to British naval prestige was equal to the loss in armament and men. The U-boat was confirmed as a potent arm of the Kriegsmarine.

The U-boats settled down to sink ships. They besieged the British Isles with a cordon of U-boats. The numbers tell the story of their efficiency. By the end of

\footnotetext{
${ }^{24}$ Botting, The U-boats, p. 80.

${ }^{25}$ The U-boats, p. 81.
} 
September German submarines sank forty-eight merchant vessels amounting to 178,644 tons. In October 1939 the U-boats sank another 150,000 tons of shipping. In November twenty-eight ships totaling 74,623 tons were sunk. The U-boats sank another thirty-seven ships of 100,413 tons in December. German lost only four U-boats. ${ }^{26}$

A favorite tactic the U-boats developed was the rudeltaktik; "the rake." A group of attack boats would range themselves like the tines of a rake and sweep an area of the sea for targets. Incoming ships found themselves encountering the enemy one after another. The groups became known as "wolf packs." During 1940 and 1941 the wolf packs formed their rakes across the Greenland-Iceland-United Kingdom gap, the Western Approaches. The rudeltaktik choked the British Isles. The orchestrator was Admiral Karl Doenitz, the German U-boat Commander, Befehlshaber der Unterseeboote (B.d.U.).

\section{The German Command}

Doenitz commanded all German submarine forces. A veteran of extensive service in both the U-boats and the surface Navy, he combined a single-minded concentration to his duties with a charismatic appeal to the sailors. He stressed the undersea service as an elite branch and instilled an aggressive zeal in its ranks. He made his U-boat headquarters first on the French coast and later in Berlin, when he was promoted to command of the entire German Navy. He had the dubious distinction of becoming the head of the Nazi state for a few weeks after the suicide of Hitler. His tenacious approach was summed up in his motto: "Advance! Attack! Sink!"27

Doenitz' strategy was simple. He insisted that victory was a matter of mathematics. Logistics, supply and demand were the overriding imperatives of this

\footnotetext{
${ }^{26}$ Piekalkiewicz, The Sea War, 1939-1945, p. 108.

${ }^{27}$ Doenitz, Memoirs; Ten Years and Twenty Days, p.119.
} 
World War. Without supplies Britain would fail. Sink her supply ships quicker than new ones could be built and victory would result. Therefore it was essential to sink as many allied merchant ships in the shortest possible time. He estimated that the British would be forced to capitulate if sinkings topped 700 thousand tons a month. Given the average gross tonnage of a freighter of the time at five thousand tons, sink 140 ships a month and victory was assured, he believed. ${ }^{28}$

To that end the U-boats scoured the Atlantic.

\section{German Surface Defeats}

The efforts of the German surface fleet did not meet with victory. Three high profile adventures by surface ships ended unsuccessfully. The first attempt to challenge British mastery of the surface of the Atlantic was the sortie of Admiral Graf Spee. In November the battleship got new camouflage, false gun turrets of plywood to disguise her identity and she sailed for the south Atlantic to do battle. The ship was not successful. After inconclusive fighting, the Royal Navy warships cornered her off the Plate Estuary. December 17, her crew opened the drain cocks and scuttled her. The sailors was interned for the war. ${ }^{29}$

In the sudden German invasion of Norway in April 1940 German troops marched through Denmark. Denmark surrendered in a day. It is worth noting the diplomatic complication this occasioned in the Battle of the Atlantic. Greenland and Iceland, occupied by nominal British forces, owed their allegiance to the Danish Crown, now hostage to Germany. The prospect of these strategic islands going under Nazi control was an alarming possibility. Both sides scrambled to set up puppet Danish regimes.

\footnotetext{
${ }^{28}$ Doenitz, Memoirs, p. 74.

${ }^{29}$ The Sea War, p. 50.
} 
Meanwhile Hitler demanded close naval support for his Norwegian invasion forces in the cramped waters of the fiords. In the fighting cruisers Blücher, Karlsruhe, Konigsberg and Lutzow were sunk. Light cruiser Scharnhorst and heavy cruiser Admiral Hipper were both badly damaged.

In May the German battleship Bismarck met a similar fate. The Royal Navy located her off Iceland. Superior British forces gave chase. Steaming desperately to reach the safety of continental Europe, Bismarck was hunted down. The British flying boat that sighted Bismarck had formerly belonged to the U.S. Navy. It was one of a shipment of Catalina's "loaned" to the British, along with liaison officers to train the British on their flying characteristics. Illustrative of growing American involvement, the co-pilot of that Catalina was an American naval officer. ${ }^{30}$ Aircraft damaged Bismarck; gunnery reduced her to a hulk; torpedoes finished her.

\section{Supply Ships and Raiders}

The size of the Atlantic as a battlefield made logistics and supply critical. Feeding the sailors, and especially the machines flung across thousands of miles of water became the determining factor controlling the seas. Before the war the German Navy discreetly analyzed the Atlantic in anticipation of conquering it. The cadet ship Charlotte investigated a hundred uninhabited locations for potential supply dumps, repair sites and safe haven. The information was required study at the German naval academy.

A network of German firms and operatives settled into Atlantic ports from Lisbon to Miami to Buenos Aires overtly as ship husbanding agents, and covertly as spies. A flotilla of supply ships was created. The tankers Charlotte Schiemann and Corrientes

\footnotetext{
${ }^{30}$ Sainbury, Churchill and Roosevelt at War, p. 19.
} 
were home ported at Las Palmas in the neutral Portuguese Canaries. Others were prepositioned at Vigo and Rio de Janeiro. The Kriegsmarine filled another dozen ships with fuel and torpedoes and posted them in remote corners of the Atlantic. The supply challenge of the battlescape should include note that the war did not confine German naval operations to the Atlantic. A squadron of U-boats took up station in the Indian Ocean. These Monsoon boats prosecuted war there by a tenuous 12,000-mile supply line back to Germany, using Japanese facilities in Malaya.

At the outbreak of war every German-flag merchant ship, and their crews, became part of the kriegsmarine. Several were converted for war. These Auxiliary Cruisers, also known as Commerce Raiders, sailed from Germany to remote parts of the world to attack unescorted Allied ships. Surprise and deception were their stock and trade. The Raiders kept the paint of merchant ships and concealed their weaponry. They flew the flags of neutral countries. Like the ancient pirate ships, the unsuspecting target never knew they faced a belligerent until too late, when the Auxiliary Cruiser showed its true colors while its deck guns were in the act of sinking them.

Secret agents, blockade-runners and pirate ships were further aspects of a war expanding over the planet. To understand the American introduction we must look for a beginning. The genesis of events leading the United States field sixteen millions of its people under arms; and creating and using weapons from atomic bombs to helium balloons. A catalyst quickening our naval involvement may be discernible. A likely starting point is the incident on the Yangtze River in China of December $12^{\text {th }}, 1937$. 


\section{The PANAY Incident}

The USS Panay was an American Navy gunboat of the China Station on a humanitarian patrol up the Yangtze between Nanking and Wuhu on that day. Beginning with involvement in the Boxer Rebellion in China, Navy ships of the American Asiatic Fleet based in Manila made regular calls at Chinese ports. In the 1920's shallow-draft American gunboats penetrated hundreds of miles up the rivers of China to show the flag on behalf of American commercial interests, and as a show of force supporting the several thousand American citizens then working there in the missionary movement in China. When Japanese Imperial Forces began their 1937 invasion of China, USS Panay came into their bombsights.

Fighting in the Nanking area between the Japanese and Chinese was vicious. A neutral feeling its way through this dangerous situation, USS Panay was underway from Nanking to collect American citizens upriver for evacuation. At State Department direction the vessel displayed three 26-by-32-foot American flags painted on its awnings to show its neutrality. ${ }^{31}$ This nicety of their diplomatic status went unnoticed or overlooked by Japanese aviators on December 12th.

Twenty-four Japanese Navy dive-bombers, torpedo bombers and fighter planes converged overhead. The flyers were sweeping the river to interdict Chinese shipping. ${ }^{32}$ They attacked the American gunboat with bombs, torpedoes and strafing. After the stricken crew abandoned the sinking ship, a boatload of Japanese soldiers drew alongside, machine gunned the vessel, and briefly went aboard to rummage. Minutes later USS Panay capsized and sank in 80 feet of water in mid-river. Three were killed in the action,

\footnotetext{
${ }^{31}$ Perry, The Panay Incident; Prelude to Pearl Harbor, 64.

32 Ibid, p.78.
} 
two Navy sailors and a civilian correspondent. A dozen of the crew forced to abandon her were wounded. The survivors hid in the reed beds along the riverbank to save themselves as Japanese pilots buzzed overhead. Eventually Chinese soldiers came to their rescue. The diplomatic row was acrimonious. Within weeks the Japanese ambassador formally apologized, representing the attack as one of mistaken identity. The Japanese aviators were issued letters of reprimand. The Empire agreed to an indemnity of a couple of million dollars. Though pressed by the U.S. Navy to go to war, President Roosevelt could only accept the apology and talk about possible economic sanctions and a quarantine of Japan. ${ }^{33}$

But in January American Navy Captain Royal E. Ingersoll departed for England on a Presidential mission to begin talks with the Royal Navy. From then on American neutrality tilted in support of Great Britain. ${ }^{34}$

To understand the Battle of the Atlantic is to have an understanding of the leaders guiding the fight. President Roosevelt was personally very interested in naval affairs. So was Winston Churchill. Beginning in his tenure as Britain's First Sea Lord of the Chamberlain war cabinet, Churchill initiated correspondence with Roosevelt. His policy was to bring the United States to Britain's side. Advancing to Prime Minister, Churchill worked to foster relations with his American counterpart. Over time the two Commanders developed an understanding that the mutual fates of both nations were joined in the outcome of the war.

That these two made a close working relationship is well known, but should be noted in any review of the Battle of the Atlantic. They corresponded daily and met

\footnotetext{
${ }^{33}$ Leutze, Bargaining for Supremacy; Anglo-American Naval Collaboration 1937-1941, p18.

${ }^{34}$ Reynolds, The Creation of the Anglo-American Alliance, 1937-1941, p. 60.
} 
numerous times in the course of the war. Their guidance focused on the maritime war. As much as anything else, the battle at sea was the joint response of these two men personally to the Hitlerian aggression. Their teamwork would converge into the AngloAmerican naval alliance and victory.

\section{Atlantic Neutrality Patrol}

Two days after the German army invaded Poland on August 31, 1939, the European Allies Britain and France declared war on her. President Roosevelt proclaimed American neutrality. At the same time he announced the creation of the "Neutrality Patrol." He declared a buffer zone in the western hemisphere along its eastern shores to be kept free of belligerents and hostilities. The U.S. Navy would keep the peace. In theory it was an idealistic extension of the Monroe Doctrine. In practice it was a step towards war. ${ }^{35}$

American cruisers and destroyers shifted from their homeport of the Pacific to the Atlantic and began patrolling 1,000 miles off the eastern seaboard. Agreements were signed permitting American military bases on Greenland. In July 1940 U.S. troops occupied Iceland, freeing the British garrison for redeployment. ${ }^{36}$ By 1941 the Neutrality Patrol was escorting United Kingdom-bound convoys as far as Iceland.

German merchant ships in United States ports were seized and interned for the duration of the war. Rules of Engagement increasingly hostile to contact with German warships came down from the Chief of Naval Operations. The Neutrality Patrol was one of the series of martial steps introducing American involvement in World War II.

\footnotetext{
${ }^{35}$ Bargaining for Supremacy, p. 55.

${ }^{36}$ Kimball, Forged in War; Roosevelt, Churchill and the Second World War, p.84
} 


\section{Ships for Bases}

Since 1939 Roosevelt had pondered how best to defend the eastern seaboard of the United States. He had served as Assistant Secretary of the Navy in the First World War, and was a keen sailing enthusiast before falling victim to the crippling effects of poliomyelitis. ${ }^{37}$ His guiding hand was the architect of American involvement in the Atlantic. Now he proposed 99-year leases on British property in the western hemisphere to set up American military bases. America would thus shore up its defense posture and, under the reasoning of a good defense being the best safeguard against war, insure its neutrality. The bases were at Newfoundland, Bermuda, the Bahamas, Jamaica, Antigua, Santa Lucia, and British Guiana. From Canada to South America, these locations would provide a tripwire of forward bases neatly including the strategic Panama Canal.

Aircraft flying from these leased stations vastly extended the range of American surveillance into mid-Atlantic. Warships of the Neutrality Patrol were greatly assisted by the same access. The new bases addressed a range of military needs, from intelligence gathering, to logistics and refueling. It was defense in depth, an outer ring of forts well in advance of the nation's homeland.

Equipment needed by the British included destroyers. From the start of his correspondence with Roosevelt, Churchill requested weapons. He repeatedly asked for fifty old United States destroyers. These were "four-stacker" World War One warships mothballed by the U.S. Navy. Although old and slow, they were nevertheless capable of naval operations. Britain was running out of money to pay for war materials. The quid pro quo was granting the string of bases to the Americans.

\footnotetext{
${ }^{37}$ Forged in War, p.18.
} 
Negotiations had a few hurdles to clear. The U.S. Navy was reluctant to part with the ships. Their reasoning was logical. Would not it better serve the nation and the Navy to hold on to the destroyers? To Admiral Stark, then Chief of Naval Operations it could not be justified. Transfer under Section 491 of Title 34 of the U.S. Code required his statement declaring the destroyers obsolete and useless. Stark refused to sign. ${ }^{38}$ Another more public dichotomy was how could the transfer of 50 warships to a belligerent at war be construed as a neutral act? While the diplomacy was going on, the war suddenly entered a new, more dangerous phase.

On May 10 the German mechanized armies with Luftwaffe close air support surged over the western border. The "Blitzkrieg" caught the Allies by surprise. Within weeks the Netherlands, Belgium, Luxemburg and half of France were overrun. Italy joined the Axis. June $22^{\text {nd }}$, France capitulated. The terms were hard. Three-fifths of France was occupied. A collaborating French government was set up in southern France at Vichy. The German U-boats moved into the French Atlantic ports Brest, Lorient, St. Nazaire, La Rochelle, La Pallice, and Bordeaux, giving them almost total access to the Atlantic.

Events continued in rapid succession. The prime ministry of Chamberlain collapsed with a vote of no confidence. Winston Churchill became the new Prime Minister. To neutralize their incipient danger, French ships in British harbors were seized. A series of British attacks wrecked the French warships that had taken refuge at the French colonial ports of Oran, Casablanca and Dakar. The French government at Vichy broke off relations with Great Britian.

\footnotetext{
${ }^{38}$ Bargaining for Supremacy, p. 116.
} 
On July 16 Germany turned to Britain. While preparing plans to invade, the Luftwaffe began a campaign to achieve air superiority over the islands. For the next few months the two air forces clashed in the dramatic aerial duel known as the Battle of Britain. London and the rest of the island were subjected to bombing day and night. The RAF retaliated with bombing raids on Berlin. But the attrition was extreme. It was the nadir of Allied fortunes.

Coming to the conclusion that the British would not survive without assistence, President Roosevelt, Secretary of State Hull and Attorney General Jackson approved the transfer of the fifty destroyers. The Attorney General issued the opinion that they could be transferred by Executive Order, freeing the Navy from certifying them obsolete. The Administration emphasized that the new overseas bases were a vital improvement to the U.S. defense and a step towards maintaining neutrality. ${ }^{39}$ The deal closed.

September $2^{\text {nd, }} 1940$ the destroyers were transferred to Her Majesty's government. The same week President Roosevelt signed the Conscription Bill.
$\underline{\text { ABC Talks }}$
That winter a series of military talks, long in the making and of highest importance to the war went on in Washington from January 29 to March 29, 1941. Known as the $\mathrm{ABC}$ (American-British-Canadian) Conference, these meetings set the strategy for World War II. Few Americans ever knew the talks were held until the war was over.
The Royal Navy battleship HMS King George $V$ sailed for America to convey Lord Halifax and his family to take over as Ambassador replacing the late Lord Lothian.

\footnotetext{
${ }^{39}$ Bargaining for Supremacy
} 
A British military delegation went along. With them came U.S. Rear Admiral Ghormley and General Lee, the principal American military attaches to our London Embassy. January 23, the warship anchored off Annapolis.

Here the presidential yacht met the travelers and President Roosevelt took aboard the new ambassador and his wife for tea and greetings. The British military leaders came ashore in civilian clothes as members of the British Purchasing Commission. They were soon ensconced in Washington. Beginning January 29, they met almost daily for planning sessions with the American General Staff.

Ghormley was given instructions for the purpose of "reaching tentative agreement, and recommending engagements, concerning the methods and nature of military collaboration between the two nations should the United States decide to engage in war against the Axis Powers in common with the British Commonwealth of Nations. ${ }^{40}$

Top military commanders of the two countries were meeting privately a few blocks from the Capitol at the very time that military aid to the British on an enormous scale was being debated under the novel approach of Lend-Lease. ${ }^{41}$

\section{$\underline{\text { Lend-Lease }}$}

During his Christmas holiday retreat of 1940 to the United States Virgin Islands, President Roosevelt pondered the dilemma. The amount of material needed by the beleaguered British was enormous. Roosevelt had concluded the United States would eventually be drawn into the war sooner or later. Both Roosevelt and the American people favored the British. How could the outcome be affected while remaining neutral?

\footnotetext{
${ }^{40}$ Bargaining for Supremacy, p. 221.

${ }^{41}$ The Creation of the Anglo-American Alliance, p. 184.
} 
On January 6, 1941 President Roosevelt addressed the nation in his radio fireside chat to explain his brainstorm of an idea for how to help Great Britain and still remain neutral. He used the famous "garden hose" simile to make his proposal one easily grasped by the listening audience. He likened the world situation to that of a family at home (America) and their neighbor (Britain). The home of the neighbor had caught fire. To put out the fire and save his home, the neighbor needed to borrow our garden hose: "Suppose my neighbor's house catches fire and I have a length of garden hose four or five hundred feet away. If he can take my garden hose and connect it to his hydrant, I may help him to put out the fire. Now what do I do? I don't say to him before that operation, "Neighbor, my garden hose cost me fifteen dollars; you have to pay me fifteen dollars for it." No! What is the transaction that goes on? I don't want fifteen dollars --I want my garden hose back after the fire is over." ${ }^{42}$

The moral of the story was that no decent soul would deny such a request, or strike a hard bargain over it in the hour of emergency. The materials being sent to England, which included 1/15 of Britain's food supplies in 1941, would no longer be sold. ${ }^{43}$ They would be lent, leased for nothing. The tale of borrowing the garden hose to save a house afire framed the proposal for free military aid.

HS 1776, the Lend-Lease agreement drawn up between the two countries was debated in Congress during the spring session. President Roosevelt focused on the measures potential for safeguarding the United States and its neutrality. March 24, 1941 Lend-Lease passed Congress.

${ }^{42}$ Their Finest Hour, p. 568.

${ }^{43}$ The Creation of the Anglo-American Alliance, p. 167. 


\section{NAG: The Navy Armed Guard}

Next came the creation of the Navy Armed Guard. Still inhibited by isolationism, it was not until November 1941 that Congress revised the Neutrality Act from restricting weapons larger than side arms from being placed aboard United States flag merchant ships. The passage of Public Law 294 removed that restriction. The White House authorized the Navy to begin arming U.S. merchantmen.

Finding naval guns was difficult to begin with, since most were going to the Navy itself. The guns found were anything that could shoot. Most were World War One vintage deck guns. Others were the newer anti-aircraft guns that would eventually arm Liberty and Victory ships. But often no more was available than machine guns. In some instances guns that would not fire were mounted for a show of force.

In anticipation of the passage of Public Law 294, the Navy had started training gun crews to serve on merchant ships. Naval Armed Guard service schools began training in Norfolk, Gulfport, and San Diego. After Pearl Harbor the tempo in the shipyards of America became frenzied.

In every port of the United States, welders and fitters hurriedly fabricated protective gun tubs, mounting weapons and installing ammo boxes and battle telephones. At the end of 1942, 1,813 merchant ships were armed in some manner. Along with weapons, Navy sailors in gun crews of from four to twenty-four men came aboard these merchant ships. Indicative of the size and importance of the program, over 144,000 Navy sailors would eventually serve aboard 6,236 merchant ships. A better indication of the 
desperate time was the number of ships, 710, which were sunk out from under the Navy Armed Guard. ${ }^{44}$

Increased activity in the Atlantic escalated contact with the Germans. The destroyer USS Niblack on April 10, 1941 off Iceland paused in its neutrality patrol to rescue the survivors of a torpedoed Dutch merchant ship. Making sound contact thought to be a submarine closing, Niblack dropped depth charges, the first American shots of the war. May 21 the U.S. merchantman SS Robin Moore was torpedoed and sunk despite sailing under the American flag. The State department demanded compensation. Germany ignored the request. President Roosevelt condemned the attack and declared a State of Unlimited National Emergency. The military reserves were mobilized at this time for the duration of the emergency; in this instance, five years.

The first wartime meeting of the two heads of state occurred that summer. Churchill embarked in HMS Prince of Wales for Newfoundland on August 4. Roosevelt aboard the cruiser USS Augusta met him five days later. The rendezvous was Placentia Bay, Canada, and out of the three day conference came the Atlantic Charter.

Titled "A Joint Declaration by the President and the Prime Minister," the onepage document was a statement of principles: neither country desired territory; both wished a return to peace. It declared respect for the rights of all peoples to selfdetermination and a desire for the economic advancement of all. Then it stated hope to see lasting peace established “...After the final destruction of the Nazi tyranny...." That the neutral United States signed with a belligerent such a joint document was profound.

44 “The Pointer," U.S. Armed Guard Association, Jan 2002, 3. 
September 4 the destroyer USS Greer made contact with U-boat U-652, after receiving a warning of the submarine's presence from a British bomber overhead. When the American ship took no action, the British plane dropped its own bombs on the Uboat. Mistaking the attacker to be USS Greer, the U-boat shot torpedoes at her. USS Greer then dropped depth charges of its own. Shots had been traded.

October 15 a German wolf pack attacking a British convoy south of Iceland inadvertently brought American destroyers to the scene for rescue operations. One of the U-boats put a torpedo into USS Kearny. The damaged Navy ship made Iceland but cost was high: eleven dead, twenty-four wounded. ${ }^{45}$ Blood was shed.

More attacks followed. The United States merchant freighter SS Lehigh was sunk off Africa. In the North Atlantic torpedoes hit Navy oiler USS Salinas. Damage control kept her afloat and she made port in Newfoundland. The USS Reuben James was not so lucky.

USS Reuben James was an old four-stack destroyer like those turned over to Britain earlier. On the last day of October she was performing convoy escort when a torpedo from U-552 hit her amidships. The destroyer broke apart. As she sank her preset depth charges began to explode, killing the survivors in the water. Reuben James was the first Navy ship sunk in World War II. One hundred and fifteen of her 160-man crew went down with her. In all but name, the United States was in the Battle of the Atlantic. ${ }^{46}$

A month of uneasy quiet followed, as many U-boats were temporarily deployed to the Mediterranean to assist German operations in North Africa. December 7 came the attack on Pearl Harbor.

\footnotetext{
${ }^{45}$ The Sea War, p. 170.

${ }^{46}$ The Sea War, p. 171.
} 


\section{The First Attack}

December $12^{\text {th }}, 1941$ the first group of German U-boats set sail on the long voyage to attack America. Code-named Operation Drumbeat, the attack caught the U.S. homeland unprepared and opened a campaign of naval offense against our shipping that nearly lost the United States the war.

In his planning for an American war, Admiral Doenitz anticipated an initial offensive of 100 U-boats. The Japanese attack on Pearl Harbor was as much a surprise to the Germans as the U.S. Only a few U-boats were available. Berlin released six, and mechanical breakdown kept one in port. Five U-boats launched the attack.

Sailing from France, the U-boats made their way across the Atlantic, traveling at a standard creep of four knots to conserve fuel. They maintained radio silence and avoided targets in route so as not to give themselves away. Upon reaching the New World they took up stations along the Eastern seaboard from Nova Scotia to Cape Hatteras. They commenced their attacks simultaneously. Operation Drumbeat began with the sinking of SS Cyclops January 12, 1942. Between then and February 6 twenty-five merchant ships were sunk, practically a ship a day. It was a stunning blow and showed clearly the American deficiencies. There was no civil defense blackout along the coast. The enemy were able to locate themselves, pick out targets, strike and withdraw, using the lights of the cities of America to orient themselves.

U.S. merchantmen were not traveling together in groups escorted by Navy warships for common defense. Despite Royal Navy urging, American ships under civilian masters were putting to sea under independent sailing orders. They encountered the enemy alone, their defenses weak or non-existent. As yet Armed Guards were posted 
only on some ships, and with makeshift arms. No small craft guarding the harbors and the coastline. Under the cover of darkness the enemy were able to slip unseen into the ports themselves. There were no Coast Watchers stationed on shore to look for the enemy. All too frequently the first and only sign of the nearness of the enemy was the burning and sinking freighters clearly visible off the coast.

Aviation was not used efficiently. Army planes flew independently of the Navy. Often their patrols duplicated each other. The ocean was not systematically covered. Wireless communications were clumsy, or even in clear. There was no battle doctrine in the event of contact. Search and rescue for survivors was uncoordinated. A vast civilian asset of thousands of civilian boats and mariners, aircraft and pilots was not used at all.

During the first week of the attack, SS Norness was sunk off Montauk Point, Long Island. The next day, the Navy airship K-3 from Naval Air Station Lakehurst, New Jersey was on the scene. The blimp located the ship's shattered bow, still floating in the water. A few miles away the airship located a life raft with four survivors. The K-3 lowered food and water and radioed for help. Then the blimp stood by until small boats came and rescued the men. It was the morning after the commencement of open hostilities against America in the Battle of the Atlantic, and a U.S. Navy airship was in the fight.

As the initial U-boats, low on fuel and torpedoes, were withdrawing, other Uboats were taking their place. Emboldened by success, Doenitz and U-boat command threw every available submarine into the battle. They were very good at sinking ships. Ruefully President Roosevelt wrote Churchill: "My Navy has been definitely slack in preparing for this submarine war off our coast. As I need not tell you, most naval officers 
have declined in the past to think in terms of any vessel of less than two thousand tons. You learned the lesson two years ago. We still have to learn it." ${ }^{, 47}$

The American Navy faced a new reality. The paradigm of battleship warfare was shattered at Pearl Harbor. The battleship was not the supreme weapon of sea power. In the most excruciating manner it had been proven they were no match for aircraft. They were helpless against it. Then the attack of the small and nondescript U-boats brought home the new kind of naval combat. This enemy avoided American warships. The Uboats struck the weak link of the American maritime; the merchantmen. The U.S. Navy as constituted was as weak against the U-boat as it was against the aircraft. The challenge inspired a new way of making war.

A subtler revolution in the maritime was evoked, a new industrial revolution in shipping. As the Nazis raced to sink ships, the U.S. raced to build them. Teamwork and standardization reduced design to one single prototype. Soon the entire shipbuilding industry in America worked off the same page. All shipyards were building the exact same ship. A container ship with five holds, attached booms and simple reciprocal engines, capable of carrying 9,000 tons at 11 knots.

The Liberty Ship it was called and 2,750 of them were built. It was by far the largest number of a single class of ships ever built. From the scraps another 531 similar smaller vessels labeled Victory Ships were cranked out. Shipyards honed their skills until they could lay a keel and launch the same ship in a week. They were functional, and sans frills. In the Tampa Shipyards an experimental project produced a half-dozen

${ }^{47}$ Kimball, Churchill and Roosevelt, The Complete Correspondence, Volume One, pp. 421-422. 
Liberty Ships with hulls of poured concrete. It was a Homeric feat of shipbuilding, the precursor to the modern container ship industry.

\section{The Hooligan Navy}

Faced with a desperate need for small craft to protect the coast, the Corsair Fleet came into being. The civilian Commodore of the Cruising Club of America on March 25,1942 volunteered to the Navy the loan of 30 sailing yachts, between fifty and ninetyfoot, with skippers and volunteer crews. These vessels were equipped with sails and gasoline or diesel engines.

By April, the offer had grown to 70 seagoing yachts and 100 smaller craft. Initially, the Navy declined the help, still wedded to its big ship paradigm. Letters and editorials flowed to those in command. The outcry caused the Navy to change its mind. ${ }^{48}$ May 4, the new Chief of Naval Operations, Admiral King, requested the Coast Guard take over and organize the "Coastal Picket Force."

The Coast Guard Reserve was initiated in 1939. By the time of the U-boat attack it had about 8,000 personnel. Legislation was passed to create a new reserve force to augment it. The new force was titled the Coast Guard Auxiliary. Congress authorized suitable men to serve for as short a period as 30 days, even though regularly disqualified for service in the Navy or Coast Guard because of age or physical problems. It was the levee en masse.

The boats were armed with machine guns and radios and Coast Guard Reservist skippers. The volunteer crews were an assortment of yachtsmen, students, Boy Scouts, and ex-bootleggers. They were sometimes called the Hooligan Navy. Walt Disney

\footnotetext{
48 "The U.S. Coast Guard in World War II, The Beach Patrol and Corsair Fleet," p.12.
} 
Studios designed the logo for the Corsair Fleet. The cartoon figure on the emblem prompted their other nickname: The Donald Duck Navy. ${ }^{49}$

On shore they were augmented by civilian volunteers organized as coast watchers, leavened by uniformed Navy and Coast Guard personnel, often riding long stretches of beach patrol on horseback. These were important measures adopted in opposition to the U-boats. Civilians, sailboats and horses all joined in the Battle of the Atlantic.

\section{Civil Air Patrol}

America's aviation industry provided another response. In this total war, total mobilization was demanded. The Tanker Committee of the Petroleum War Council first met on March 4 in Washington with representatives of the Army and Navy. The agenda was the grave loss of tankers. By then sixty-five ships had been sunk, twenty-seven of them tankers. Being only fifty days into the war at that time, and having lost a tanker every other day, at that rate the 320 U.S. tankers would be decimated by the end of the year and non-existent by the end of the next. The Tanker Committee proposed mobilizing the civilian aviation community. It met with the interest of the Army Air Corps representative, Major General Carl Spaatz. ${ }^{50}$

First organized under the Army's Air Support Command, civilian pilots began flying their planes on daylight air patrols extending sixty miles offshore over the shipping lanes. The Army supplied fuel, and some of the planes were armed with a depth charge or a pair of bombs. The pilots, many of them women, wore specially designed uniforms in the event of capture. Twenty-one Civil Air Patrol units were established from Maine to Texas, with hundreds of civilian airplanes participating. The Civil Air Patrol flew

\footnotetext{
49 "The Beach Patrol and Corsair Fleet," p.16.

${ }^{50}$ Gannon, Operation Drumbeat, p. 343.
} 
244,600 hours on 86,685 missions. These planes in the air helped keep the U-boats down and were a practical response to the attacks.

\section{Queen Ships}

Not all these expedients succeeded. The Q-Ship, a weapon of deception used against U-boats in the First World War, was again resorted to. A swift, heavily armed merchantman was disguised with false smoke stacks and structures to present a misleading identity. Q-ship holds were filled with empty steel drums or pulpwood for floatation. Empty crates stacked on deck added to the appearance of what it was not; a lumbering merchant ship and an inviting target. Plywood blinds concealed its guns.

The deception of the Q-Ships was elaborate. False names and hull numbers were painted on bow and stern. Navy sailors disguised as civilians walked the railing. Phony radio messages went from the Q-ship under the guise of its false identity. Equally false messages were sent to it. All designed to trick the U-boat into attacking.

Once the U-boat took the bait and attacked, the play began. To save precious torpedoes U-boats would often surface and use their deck gun to sink an enemy. Knowing this, the Q-ships were prepared. The crew lit off handy stacks of mattresses, pretending or exaggerating battle damages with smoke and fire. The crew gave a convincing demonstration of abandoning ship by lowering lifeboats. Designated actors would row away from the vessel, giving the perfect impression of defeat at sea. Until the U-boat closed in for the kill. Then the gunners in hiding aboard the Q-ship opened fire at close range.

So it worked in principle. 
The ruse was resorted to in late January of 1942 by the U.S. Navy with the purchase of three civilian steamers. SS Wave, SS Carolyn and SS Evelyn were disguised, heavily armed, and covertly commissioned into the Navy as USS Eagle, USS Atik and USS Asterion. All volunteer crews of Navy sailors manned them. Bold in conception, they were nevertheless unsuccessful. Neither USS Eagle nor USS Asterion ever made contact. Eventually their secret operations were discontinued and they became just two more ships of the surface fleet.

The fate of USS Atik was sadder. On her maiden voyage she encountered U-123. Taking her for a civilian cargo ship, the submarine put a torpedo into her and surfaced to finish her off with the deck gun. Not badly damaged, USS Atik played her part well, half of her crew taking to boats in mock evacuation. When the submarine was within range USS Atik opened up with her own deck gun and small arms, killing a German on the conning tower. The U-boat quickly submerged. Taking a new angle she put another torpedo into the Q-ship. This time the ship went down. None of its lifeboats reached land. USS Atik was lost with all hands. ${ }^{51}$

\section{Milk Cows and the Wizard War}

Waging war across the ocean boiled down to fuel. Type VII attack U-boats could carry only enough fuel and provisions for a 7,000-mile voyage. After crossing the Atlantic, they barely reached the front before they had to return. The gas tank was the Achilles heel of the U-boat war. Despite great losses, the British staved off defeat by concentrating on this vulnerability.

\footnotetext{
${ }^{51}$ Operation Drumbeat, pp. 323-329.
} 
The "Wizard War," Churchill described this focus on scientific applications harnessed to combat. The Battle of the Atlantic was an intelligence battle. Much has been written concerning the Allied intelligence success in cracking and reading the German Enigma message system. But repetition has trivialized this feat as a foregone conclusion, drawing away from both the reality at the time and the importance of the achievement. The fact is, both sides were engaged in wholesale espionage and counterespionage on a grand scale. Allied success was a very near thing, and in no way a given.

From the onset of war the British worked hard cracking the German code. They begged, borrowed or stole as much German communications gear as they could. Contributions from Poland and France were augmented by gear seized in commando raids on the Lofoten Islands of Norway, the capture of German weather ships and the submarine U-110. They began reading German naval codes in summer of 1941.

From June 1941 to the following January they used the information for a calculated counter-attack. They attacked not the U-boats, but their fuel and supply ships. One by one Belchen, Gedania, Friedrich Breme, Gonzenheim, Alsteror, Lothringen, Esso Hamburg, Egerland, Babitonga, Kota Penang, Benno, Atlantis and Python were run down and sunk. With well-founded suspicions, Doenitz ordered a fourth rotor added to the Enigma deciphering machine and changed to a new code named "Triton." The screen went blank and it was over a year before the British would again be reading his signals. ${ }^{52}$ Much of the time the Nazis enjoyed the upper hand in eaves dropping. German agents were tapping Ten Downing Street and White House telephone calls. The German Secret Service Beobachtungsdienst, B-dienst for short, penetrated British Naval Code

${ }^{52}$ Meigs, $\underline{\text { Slide Rules and Submarines, p. } 71 .}$ 
Number Three, lifting the veil on allied communications of British and American convoys. By July of 1942 they were reading 80-percent of that code. ${ }^{53}$ Meanwhile the kriegsmarine Triton code was impervious to the Allied code breakers. It was only by dint of the greatest efforts and perseverance that the Allies ultimately pulled ahead and triumphed in the intelligence war.

The British location and removal from the battlefield of the German fuel and supply ships precipitated the introduction of a new technology and combat platform at sea: the U-Tanker. German plans for such were drawn up as early as 1926 . The plan was to build a much larger U-boat with extra fuel tanks. The boats would have no torpedo tubes or armament other than anti-aircraft guns topside. The space would be devoted to fuel. The U-Tanker was equipped with pumps and hoses for refueling at sea. The UTanker would also carry spare parts, provisions, and even a few torpedoes with which to supply the attack boats.

At the start of the war Doenitz gave specifications for these supply submarines to the High Command. Contracts for the first four of ten such vessels were placed with Deutsche Werke, Kiel in May of 1940. That November the first keel was laid. Because of their complexity the U-tankers took longer to build than attack boats - about ten months on average. They began to reach the battlefield just when the U-boats began attacking America.

Stationing themselves in mid-Atlantic, the U Tankers were an invaluable assistance to the attack boats, now prosecuting highly successful attacks upon the enormously expanded front of the American Eastern Seaboard. The U-Tanker could

\footnotetext{
${ }^{53}$ Slide Rules and Submarines, p. 77.
} 
refuel the attack boats on their outbound voyage or return, or both. Either way, they doubled or even trebled the range of the attack boats and prolonged their time on station in the target-rich killing zone that much longer. The Battle of the Atlantic now extended throughout the Gulf of Mexico and into the farthest reaches of the Caribbean and South America. Fuel was decisive.

The Allied intelligence breakthrough deciphering Triton came in May 1943. Carefully the Allies exploited the intelligence, again aiming to remove the floating Nazi gas stations from the board. It was a critical move. The scales of war were beginning to tip at the time the U-boat 134 put to sea on its last patrol.

Besides inspiring a revolution in wireless communication and machine languages, the Battle of the Atlantic saw advances in technology in other areas. Broadly skimming this immense field of study we can note a few applications to the sea war as both sides produced new devices and war making means. Some were practical, some less so. Midget submarines in time were reduced to the irreducible; piloted torpedoes. Teflon was invented to coat the decks of U-boats to diminish their radar signatures. In vast shipbuilding effort of America, steel shortages caused some experimental cargo vessels to be made of poured Portland cement. It "paved" the way for the concrete forms and prefabricated building materials technology of modern times.

An imaginative chemistry application was the pillenwerfer, canisters of compressed bromides the submarines carried. When caught submerged in difficult situations the U-boat would discharge these canisters into the sea. Upon contact with water the pillenwerfer would bubble and fizz like giant Alka-Seltzer tablets. The noise distracted enemy sonar, while the U-boat stole away. 
More fantastic was the Bachstelze. Some U-boats carried these early para-sailing contraptions. On a windy day with a calm sea state, this kite with a rotor was brought on deck. There was a harness for a pilot. The kite was towed by the U-boat, caught the wind, and with the observer strapped in, soared aloft. Flying hundreds of feet above the ocean, the observer used his binoculars to look for targets. Because of slowness in reeling the Bachstelze aboard in the event of surprise attack, the observer wore a parachute. The idea was that the observer would parachute from the Bachstelze and regain the boat far quicker. ${ }^{54}$

"Fido" the first smart bomb, was fiendishly simple. Initially Allied depth charges and depth bombs were dumb; drop them in the water, they explode. Scientists developed a torpedo with ears. When dropped into the water the acoustic homing torpedo had sound sensors that would pick up the noise of the U-boat engines. Homing devices kicked in and "Fido" chased after its noise. Contact meant doom.

ASDIC (the British version of radar), sonar and Magnetic anomaly devices for detecting large masses of metal under the water all played parts. "Huff-Duff" (High Frequency Direction Finding) was a scientific means of message triangulation. When a signal was sent by a platform at sea, it could be heard by anyone listening. If three such listening stations picked up the signal at the same relative strength (frequency), a triangulation of their own positions could reveal a rough fix on where the signal came from. The fix was least precise when taken from ships underway at sea, of these the big aircraft carriers were most reliable. Better were stationary shore stations at lighthouses

\footnotetext{
${ }^{54}$ White, U Boat Tankers, 1941-1945,
} 
and on promontories around the Atlantic. The top-secret installation in Miami for monitoring signal traffic was located in the Cape Florida Lighthouse on Key Biscayne.

\section{Enter the Blimps}

The use in World War II of airships has often been overlooked in favor of focusing on our more dramatic aircraft carriers, fighter planes and battleships. But the airships were cheap and could be mass-produced in large numbers. World War II was a competition of economies of scale; airships were inexpensive. A fleet of $135 \mathrm{~K}$-ship Patrol Zeppelins flew over our coasts. Navy airships deployed overseas to North Africa, Italy and France. In the Battle of the Atlantic the airships weighed in heavily.

In addition to the K-ships were a few dozen auxiliary blimps of the G-Class used for flight school, photographic, calibration, torpedo recovery and similar utility tasks. A miscellaneous collection including some from the Army's phased out airship program were also used in training and coast watch activities. ${ }^{55}$

K-ships, organized into five Airship Wings and a dozen squadrons, played a vital role in homeland defense. They hovered on station guarding the harbors and the choke points of the sea-lanes. How close the enemy came should not be overlooked. Enemy Uboats ranged Long Island Sound, the mouth of the Mississippi River and even sowed mines in Chesapeake Bay, the home waters of the Navy.

Like coastal blackouts and new construction of Sub-chasers and Patrol Craft, airships were another response to the enemy attack. Built by Goodyear in cooperation with the Navy, the K-ships carried radio, radar, and sonar arrays. Their crew of ten was armed with four 500-pound depth bombs and a machine gun in the nose of the blimp car.

${ }^{55}$ Vaeth, Blimps and U-boats, p. 27. 
It was with just such weapons the U.S. Navy K-74 attacked the U-134. But much more important than their offensive armament, the blimps were a deterrent.

The blimps, although slow, ungainly, and even comical in appearance, possessed technological attributes that made them a menace to the U-boats. The U-boats, despite their name, did most of their traveling on the surface of the ocean powered by diesel. When they dove for action, electric systems engaged, but their speed was reduced to 4-6 knots. Their effectiveness declined accordingly. ${ }^{56}$ This the Navy K-ships did simply by being on station, and thereby forcing the enemy underwater to escape detection.

A grimmer extension of this capacity to degrade the U-boat speed occurred if the U-boat remained underwater. The blimp could stay on station indefinitely, unlike the fixed wing aircraft flying its patrol at over $100 \mathrm{mph}$. When the presence of a Navy airship forced the U-boat under to escape detection, the sub had to remain under until the K-ship departed. The longer the U-boat was submerged, the more oxygen its crew used up. Kept under long enough and the hapless submariners became light-headed. Asphyxiation resulted. The enemy then had ultimately to clear the area or suffocate.

These aspects of Airship ASW came into full play as the convoy system emerged. Assistance to the convoy was their greatest contribution. As the Navy adapted and improvised to overcome, the convoy rose in importance. As the United States turned to convoy shipping on a Homeric scale, the Navy blimps went with them. A K-ship overhead meant that their unique capacity to keep the enemy underwater, slow them down, and force them away, sheltered the convoy ships below. "They were Dependable" was the motto of the airships and they were.

\footnotetext{
${ }^{56}$ Doenitz, Memoirs, p. 115
} 
From the enemy perspective, sighting a blimp was a wry circumstance. Because of their stationary elevation in the sky above the battlescape the airship platforms crammed with radar and lookouts could literally look down over the horizon. Over the horizon was the enemy, riding on the surface seeking signs of targets; smoke from stacks, wake trails, flotsam and jetsam. Sighting an airship indicated that below the horizon there were unseen ships under the blimp. But if the surfaced U-boat could see the blimp, it also meant the blimp could see them. Conceal themselves by submerging and all chance of finding a target was gone. Although several were attacked and damaged, no convoy ever lost a ship while a Navy airship was overhead.

In addition, they helped the Hunter-Killer groups of escort carriers and destroyers once contacts were found. The escort carriers were lethal to the Nazi offensive, and they did it with help from the K-ships. Their radar and sonar tracking abilities helped seal the fate of the U-boats. Usefulness at finding and rescuing downed aviators and shipsinking survivors was yet another dimension of their contribution to the fleet in winning the Battle of the Atlantic. 


\section{CHAPTER III. THE VOYAGE OF U-134}

Much is known concerning the first eight patrols of U-134.

Bremer Vulkan of Vegesack built U-134 in the Bremen shipyards. Her keel was laid September 6, 1940 and she was launched May 17, 1941. The boat was commissioned into the German Navy July 26, 1941. The boat, a standard class VIIC boat, was assigned the feldpost, German military postal address, of M $45658 .^{57}$ She was seven hundred tons, powered by diesel engines and a back up system of electric motors for power when submerged.

The boat was commissioned under KapitänLeutnant (Lieutenant Commander) Rudolf Schendel. From July through October she underwent sea trials in the Baltic as a part of the $5^{\text {th }}$ U-boat training flotilla. In November she was assigned to the $3^{\text {rd }}$ Flotilla at La Pallice, France. However, she was cross-assigned to the Norwegian theater of operations and her first patrol was to Norway. ${ }^{58}$

December 1, 1941 she departed Kiel for the northern tip of the Scandinavian Peninsula. 12 days later she put in at the far northern naval station of Kirkenes. It was a short patrol and an inauspicious beginning: rounding the North Cape on December 9 she happened upon a steamer running darkened. The U-boat went to battle stations and proceeded to sink her. The ship turned out to have been the 2,2000 ton German steamer Steinbek, one of her own. An inquiry upheld Schendel, but it was an unfortunate start. ${ }^{59}$

She departed Kirkenes for her next patrol on Christmas Day, 1941. Hunting in the Barents Sea, her luck improved and she sank the British freighter Waziristan on

\footnotetext{
${ }^{57}$ U-boat Operations of the Second World War, Volume One, p 109.

58 Bredow, Einsatzdaten, U-134.

${ }^{59}$ Einsatzdaten, U-134.
} 
January 2, 1942, 5,135 tons. U-134 Returned to Kirkenes January 20. Her third patrol out of Kirkenes for further operations in the Barents Sea as part of battle group Ulan, February 2-20, was uneventful. March 1 she departed Kirkenes on her fourth mission, being ordered to Kiel and arriving there on March 15. Her fifth patrol took her from Kiel to La Pallice, May 18-June 1. U-134 reported for duty to $3^{\text {rd }}$ Flotilla West at that time.

June $11^{\text {th }}, 1942$ the boat sailed on her first long Caribbean operation. She refueled in mid-Atlantic via U-459. July 7 she attacked the Swedish merchant ship Venezia, without decisive results. On August 4, she attacked the British destroyer HMS Gleaves in Santaren Channel off Cuba, again without a sinking. On August 6 Schendel reported himself too ill to continue the 84-day patrol. September 1 she returned to La Pallice.

Her seventh sortie on October 15, 1942 took her to the Equator for operations in the Freetown Narrows between Africa and Brazil. November $13^{\text {th }}$, she refueled from tanker U-462. November 14, she sank the merchantman Scapa Flow, 4827 tons, off the Cape Verde Islands. ${ }^{60}$ The morning of January 15, U-134 was off Freetown and ordered to begin returning to homeport. One of her crew, Funkgefreiter (Radio petty officer) Gerhard Rataj killed himself in his bunk with a pistol about 0700 . He was committed to the deep the same morning. ${ }^{61}$ U-134 reached La Pallice January 19.

While the boat was undergoing refit in the French submarine pens at La Pallice, she had a change of command. Due to his health problems, Schendel was relieved by Oberleutnant zur See (Lieutenant) Hans-Günter Brosin. Brosin was born in Hanover November 25, 1916. He entered the Navy in the Class of 1936 at the German Naval

\footnotetext{
${ }^{60}$ Einsatzdaten, U-134.

${ }^{61}$ Kriegstagebuch, U-134, eighth patrol.
} 
Academy at Flensburg. He was commissioned in 1939 into naval aviation and served there the next two years. In September 1941 he transferred into the U-boat service.

He underwent U-boat training for the next year, serving in the Baltic on shakedowns, then as a watch officer with $3^{\text {rd }}$ Flotilla. He attended a prospective commanding officers course from June to July, 1942. This was followed by a month at Hamburg Warship Construction Information Division for familiarization with newly built U-boats. He took command of U-634 in August 1942, again with the $5^{\text {th }}$ training flotilla. The following March, 1943 he was ordered to assume command of the frontboot U$134 .^{62}$

March 6, 1943 U-134 sailed on her eighth patrol, her first under Brosin. She hunted between Iceland and Newfoundland in company with the Stürmer battle group. Encountering an allied convoy, U-134 could not attain a firing solution, and was subjected to a depth charge attack by convoy escorts the morning of March 19. Brosin's handling met with the approbation of U-boat Command in its after-action assessment appended to the patrol war diary. ${ }^{63}$ Inclement weather suspended operations in late March. U-134 regrouped as part of wolfpack Meise. She engaged Halifax Convoy 234 without result, but again with the approval of U-boat Command. She returned to port May $2^{\text {nd }}, 1943$.

Every U-boat captain maintained a kriegstagebuch, a war diary, while on patrol. The standard log was composed on pre-printed pages ruled in three-column format. The left hand column was headed at top of page Tag/Uhrzeit and contained room only for typed date-time groups. The second column was headed Ort Wetter, slightly roomier for

${ }^{62}$ Einsatzdaten, U-134.

${ }^{63}$ Kriegstagebuch, U-134, eighth patrol. 
noting of location or weather. The right hand column labeled Vorkommnisse occupied two-thirds of the page dedicated to descriptive data of situations and events.

B.d.U. Operations Section kept a proxy war diary on pages of the same type, consisting of a $\log$ of the radio messages to and from each deployed U-boat in more or less sequential order, with occasional annotations, during the ship's absence. Upon returning to port, the U-boat kriegstagebuch was typed up and submitted to B.d.U. After scrutiny by the higher command the kriegstagbücher were then archived. The Allies at Castle Tambach near Coburg seized these German Navy records in April 1945 and transferred them to the British Admiralty for exploitation. The U.S. Office of Naval Intelligence microfilmed these materials between 1945 and 1947. Between 1968 and 1978 the National Archives accessioned these microfilm from the U.S. Navy. Today they are accessible to the historian and the general public as National Archives microfilm publication T1022.

The U-134 never returned from its ninth patrol and so submitted no kriegstagebuch. The record of its last patrol is contained in the B.d.U. diary of radio messages sent to the boat, and received from it. These two-pages are the surviving record. ${ }^{64}$ Twenty-two messages in all are recorded. Fourteen radio messages were sent to the U-134 in the course of its patrol, eleven from B.d.U., and three signals from Führer der Unterseeboote West, the Third Flotilla in France, their immediate superior in the chain of command. Included also are a sighting report by U-653, and a report from U537 on U-134 refueling successfully. Interspersed with these were six messages received from U-134 during the course of its patrol. Following the last contact with the U-boat are

${ }^{64}$ Kriegstagebuch U-134, final patrol. 
notes reporting the boat missing in action as of September 15, 1943, and declaring the boat presumed lost March 6, 1944. The diary was then signed-off on by the B.d.U. Operations Chief and closed.

These messages should be approached in matters of study with a grasp of the seriousness with which they were made. These wireless transmissions had the gravity of the life and death issues of those involved.

Her communications were handled by radio. Normally her short-wave messages were transmitted while surfaced. Any great submerged depth thwarted her attempts to communicate, although the boat could send its messages from periscope depth. The Uboat could receive messages from two sources. Incoming messages to the U-boat from their Third Flotilla at La Pallice were sent by German radio operators in the coastal town of Kernevel, France. These were connected by landlines with the powerful transmitters and receivers of the former Compagnie Radio-France. This system located near Paris had been used by the French government for communicating with its colonial possessions around the world. It had been seized by the Germans and employed in the war effort. Transmitters were at Sainte-Assise and receivers at Villecresnes.

Long wave messages from Navy headquarters in the Berlin suburbs were transmitted from the giant antenna farm south of Magdeburg codenamed Goliath. Uboats at sea could receive these messages anywhere around the world, whether surfaced or underwater to the depth of twenty-five meters. Flotilla communications in France were also linked by cable to the Goliath network. ${ }^{65}$ The messages of U-134 follow:

\footnotetext{
${ }^{65}$ Gannon, Operation Drumbeat, p. 68.
} 


\section{2}

$\underline{\underline{-9.6}}$ La Pallice $\quad$ Werftlagezeit. ${ }^{66}$

May 2-

$\underline{\text { June } 9}$ La Pallice At anchor.

U-134 was tied up in the submarine pens. Most of her crew was on liberty in the nearby French towns while the boat was being prepared for her ninth patrol.

\section{$\underline{10.6}$ a 6 ausgelaufen mit Befehl, CG 11 anzusteuern. ${ }^{67}$}

June 10 " Get underway. Set a course for CG 11.

These directions ordering the U-boat to sea require no explanation. They have been ordered to set sail from La Pallice, clear the Bay of Biscay and make for CG 11, the waters due west of Spain and Portugal. This first operational signal gives some idea where the boat will deploy. Following the great circle of the earth, these waters lead due west to the Eastern Seaboard of the United States. Some digression to understand the Kriegsmarine navigational method is here a propos.

In the years before the start of World War II the German Navy studied its communications methods for security. To protect their references to locations they devised a new alphanumeric chart. On the topographic map the oceans of the world were divided up into grid squares. Starting at true north, each grid square was assigned a twocharacter label in alphabetic sequence. Each grid square was then divided into nine equal squares, labeled consecutively 1-2-3, 4-5-6, and 7-8-9.

Each numbered square was then further divided into another nine equal squares, again labeled consecutively 1-2-3, 4-5-6, and 7-8-9. Thus a two-character 4-digit location identified a discreet space of ocean a few miles square. By 1943 the reverse

\footnotetext{
${ }^{66}$ Kriegstagebuch U-134, final patrol.

${ }^{67}$ Ibid.
} 
method converting to latitude/longitude was well known to the allies but still practiced by the Germans for the slight advantage of the time required to transpose. Grid location CG marked the waters of Spain from Cabo Fisterra to Malaga. Location 11 was that square's northwest point, just out of range of UK-based allied aircraft and a logical starting point for a deployment across the Atlantic to the United States.

Just prior to their departure on this, their ninth war patrol, officers and men mustered topside and roll was taken. A copy of the crew manifest was left behind with the Lorient station keepers. The following 48 personnel sailed:

NAME

Batsch, Dietrich

Bau, Gunter

Brandenbusch, Gunter

Bressau, Willy

Brosin, Hans-Gunter

Cichon, Paul

Dabow, Bernhard

Ennen, Heinrich

Gorius, Anton

Grossmann, Erwin

Henze, Otto

Herber, Johann

Hoffmann, Erich

Justen, Peter

Kaiser, Martin

Kirstein, Rolf

Kleemann, Johann

Kohl, Rudolf

Kosbas, Rudolf

Leipold, Johann

Lockel, Willi

Lorenz, Gunther

Ludwig, Willi

Lützenkirchen, Wilhelm

Müller, Hermann

Munzberger, Oskar

Nehls, Helmet

Perzl, Otto
RANK

Fähnrich

Mechanikgefreiter

Leutnant

FunkObergefreiter

KapitänLeutnant

Oberbootsmannmat

OberfunkMaat

Maschinengefreiter

FunkObergefreiter

Matrosengefreiter

Obermaschinenmann

MaschinenObergefreiter

Mechanikgefreiter

Obermechanicmaat

Maschinenobergefreiter

Maschinenobergefreiter

Matrosenobergefreiter

Maschinenobergefreiter

Oberleutnant

Maschinengefreiter

Maschinengefreiter

Mechanikobergefreiter

Maschinenmaat

Oberbootsmannmat

Matrosenhauptgefreiter

Matrosengefreiter

Matrosengefreiter

Maschinengefreiter
BIRTHDATE

$28 / 08 / 23$

$07 / 03 / 25$

$03 / 07 / 22$

$12 / 01 / 23$

$15 / 11 / 16$

$15 / 03 / 20$

$25 / 10 / 13$

$30 / 09 / 24$

$20 / 02 / 22$

$26 / 02 / 24$

$29 / 04 / 14$

$03 / 09 / 19$

$12 / 01 / 23$

$18 / 03 / 19$

$01 / 09 / 23$

$28 / 07 / 22$

$25 / 10 / 23$

$11 / 02 / 23$

$20 / 10 / 19$

$01 / 10 / 21$

$02 / 09 / 22$

$10 / 09 / 23$

$09 / 04 / 21$

$07 / 12 / 19$

$15 / 01 / 21$

$23 / 07 / 24$

$09 / 12 / 23$

$30 / 05 / 23$ 
Proch, Karl

Reckzeh, Martin

Rohde, Werner

Schlickum, Bodo

Schmitz, Wilhelm

Schnabel, Rudolf

Schulte, Franz

Schulze, Heinz

Seidel, Helmut

Stein, Horst

Teuchert, Herbert

Theess, Otto

Tomalak, Leo

Uhlig, Walter

Ulbrich, Otto

Venske, Herbert

Vogler, Kurt

Walk, Werner

Wegner, August

Weismuller, Hans
Matrosengefreiter

$19 / 01 / 25$

Maschinenmaat

Maschinenobergefreiter

$05 / 01 / 21$

$25 / 07 / 23$

Obermaschinenmaat

$26 / 10 / 19$

Funkmaat

Matrosenobergefreiter

Obersteuersmann

Matrosenobergefreiter

Maschinenmaat

Matrosenobergefreiter

OberMaschinenmaat

Matrosengefreiter

Maschinenobergefreiter

Matrosenobergefreiter

Oberleutnant(Engineer)

Maschinenmaat

Maschinenobergefreiter

Obermaschinenmann

Obermaschinenmaat

Bootsmannmaat
$04 / 06 / 21$

$09 / 05 / 23$

$11 / 03 / 15$

$19 / 11 / 22$

$20 / 07 / 18$

$27 / 02 / 22$

$13 / 04 / 17$

$17 / 06 / 24$

$01 / 04 / 22$

$17 / 01 / 20$

$29 / 08 / 13$

$21 / 12 / 23$

$22 / 02 / 23$

$13 / 09 / 16$

$13 / 10 / 18$

$04 / 05 / 23^{68}$

Analysis shows that under KapitänLeutnant (Lieutenant Commander) Hans-

Günter Brosin were forty-seven sailors. There were three Watch Officers, 3 Warrant

Officers, seven Chief Petty Officers, thirty-three junior enlisted men, and one German

Naval Academy midshipman (Fahnrichner.) The crew were apportioned to the

traditional groupings aboard any warship: Deck division Boatswains (Bootsmannsmaate)

and Seamen (Matrosen). Operations Division Maschinenmaate; torpedomen and

gunners. Engineering Division; mechanics. And lastly, Administration: The

Commanding Officer, his Executive Officer, the Navigator (Obersteuersmann), a Chief

Radioman (Oberfunkmannmaat) and three communications petty officers. The

Midshipman would ordinarily muster with these.

$\frac{13.6}{17.07} \quad \frac{\text { Von B.d.U.: }}{\text { Neue Ansteuerung ist DF 50. }}{ }^{69}$

${ }^{68}$ Bredow, U-boot Archiv, Stiftung Traditionsarchiv Unterseeboote. 
$\underline{\text { June } 13^{\text {th }}}$

From B.d.U.:

1707 Hours $\quad$ Steer a new course for DF 50.

The course ordered is west by southwest into the middle of the Ocean. The boat deployed towards North America. If South America were its intended attack area, the general mid-Atlantic destination heading would have been farther south than DF. From the amount of southerly course change from CG11, it may be further deduced that the boat was being directed towards the southern United States or possibly the Windward Islands of the northern Caribbean.

\subsection{Passiermeldung durch U 653. ${ }^{70}$}

2145 Hours Sighted by U-653.

This report by U-653 indicates two relevant military facts in a single transmission. Both U-134 and U-653 were deployed from La Pallice on the same day. Both were destined for the Caribbean. By breaking radio silence at this time U-653 is reporting the relevant fact that U-134 had cleared the approaches of the Bay of Biscay and reached the open Atlantic. Before a boat could be deployed onto the offensive it first had to clear the dangerous coast of Europe, and the higher command had to know it.

The second bit of information in the transmission is that without saying a word about itself, U-653 is economically reporting that she too has made the high seas and is available for deployment.
$\underline{14.6}$
03.13
Von B.d.U.:
10.00 Uhr "Irland" schalten. ${ }^{71}$
June 14
From B.d.U.

\footnotetext{
${ }^{69}$ Kriegstagebuch U-134, final patrol.

${ }^{70}$ Kriegstagebuch U-134, final patrol.

${ }^{71}$ Kriegstagebuch U-134, final patrol.
} 
0313 Hours

At 10 am switch your radio to "Ireland" frequency.

This signal concerns self-explanatory directions for command and control. As U134 rounded the globe towards its appointed destination ever farther from the Goliath communications system in central Europe it was necessary to remain in contact over differing wavelength frequency bands.

\section{$\underline{18.6}$}

$\overline{18.28}$

June 18

1828 Hours
Von B.d.U.:

U 134 entgegen bisherigem Befehl in CE 76 bzw. 79 warten. Später Versorgung vorgesehen. ${ }^{72}$

From B.d.U.:

U-134 disregard previous orders. Heave to between CE 76 and 79 respectively. Your resupply will be later.

This message concerns itself with the refueling and provisioning of U-134.

Whatever plans for refueling U-134 sailed under had changed. The matter of fuel was paramount to military operations. Five of the wireless transmissions of the U-134 log concern ocean refueling. Some of the urgency of command and control over battlefield refueling can be gleaned from the indefinite tenor of the message. U-134 is directed to a two-grid size sector and ordered to stand by. An examination below of the kriegstagebuch of U-tanker refueling submarine U-488 sheds addition light on this transmission.

$\underline{20.6}$

10.27

June 20

1027 Hours
Von B.d.U.:

U 488 sofort nach CE 4967 verlegen. U..., U 134 aus $U 488$ auf volle Bestände auffüllen. ${ }^{73}$

From B.d.U.:

U-488 shift immediately to CE4967. U...

U-134 will refuel from U-488 a full complement.

${ }^{72}$ Ibid.

${ }^{73}$ Kriegstagebuch U-134, final patrol. 
This message identifies U-Tanker milch cow U-488 and a rendezvous point. The order that U-134 take on as much fuel as she can indicates the Nazi resolve. As a fully armed outbound boat, the U-134 was on the offensive and taking the war to the enemy. Therefore every drop of fuel she could hold was to be allotted to her to increase her effectiveness to the maximum. A study of the record details just how complex this refueling procedure was, all of it orchestrated at B.d.U. direction. The war diary of U488 survives. $^{74}$

This was the first patrol of the U-488, she returned from it and on her return to port filed her kriegstagebuch. The war diary of U-488 illustrates the entire dicey business. U-488 was one of the last tanker submarines to be built. Her keel was laid January 3, 1942; she was commissioned February 1, 1943 and sent on her first mission May $18^{\prime}$ her bunkers brimming with fuel. Her patrol was a striking operational success. Between June 7 and June $12^{\text {th }}$ she first refueled fourteen attack boats in mid-Atlantic west of the Azores. June 7 she was busy with U-558, U-666, U-232 and U-435. On June 8 she refueled U-951 and U-642. The 10th she refueled three boats; U-641, U-211 and U-336. Next day still another three; U-603, U-288 and U-953. On June $12^{\text {th }}$ she refueled U-221 and U-608. These were the attack boats of the Trutz Gruppe, a wolf pack bound for the north Atlantic. ${ }^{75}$ U-488 was ordered to rendezvous with U-170, U-535, and U-536. These larger type IX boats had been directed to stand down from their attack missions. They were to act as auxiliary tankers, transferring their spare fuel to U-488 for another batch of Type VII attack boats being vectored to her. The military decision to empty these three boats can only have been based on their comparative lethality. The type IX

\footnotetext{
${ }^{74}$ Kriegstagebuch U-488, May 18-July 10, 1943.

${ }^{75}$ U-boat Operations in World War II, p. 319.
} 
boats had much greater range and operability than the Type VII. Each carried fifteen torpedoes. So these three boats had the capacity to sink a maximum of forty-five ships. But all things being equal to this logic, the nine Type VII boats coming to get fuel carried 14 torpedoes apiece, the capability to sink one hundred and twenty-six ships.

The message to U-134 dated June 18 directing her to lay about between CE76 and 79 was also sent to her outbound traveling companion U-653, and to U-358. The signal is paragraph number 2 of a longer two-paragraph message sent in its entirety to U-488 (and dutifully copied into her war dairy). ${ }^{76}$ Paragraph number 1 of the message directs the U-488 to location CE7895. To these coordinates nine attack boats are being guided, together with the aforementioned larger IX boats. This position is southwest of the Azores and here a second major refueling operation was executed between June 18 and June 30. Assisted by U-170 and U-536, milch cow U-488 supplied another twelve boats. ${ }^{77}$

With the tankers regularly shifting position within the designated quadrant, the attack boats linked up to them for refueling one after another. The waters off the neutral island groups of the mid-Atlantic were often the scenes of refueling. The island masses broke up allied radar patterns. They may also have been favored on account of clandestine contact with island sympathizers early in the war, and later because proximity to land gave the U-boat crews a degree of survivability in the event of allied attack. U134 arrived on station June 23. She was hailed and advised by the bridge signalman of U-488 to take up a security watch. For the next forty-eight hours she remained quietly on security watch in the area.

\footnotetext{
${ }^{76}$ Kriegstagebuch U-488, p. 31.

${ }^{77}$ U Boat Tankers, p. 150.
} 
The entire evolution of refueling at sea -- submarines stopped in closest proximity to each other for hours, connected by fuel hoses and entangled with all the mechanics and business of logistics, was an extremely dangerous moment. Allied attacks in the midst of refueling operations were catastrophic. One by one the boats came alongside the tankers for their precious fuel. Their inflatable rubber rafts went back and forth supplying and trading with each other in torpedoes, food, motor oil, parts and even such incidentals as phonograph records and chess sets.

23.6

15.47

June 23 1547 Hours
Von B.d.U.:

Nach Durchführung Ergänzung DN 10 ansteuern. $^{78}$

After refueling proceed to DN 10.

At 1400 on June 26 it was her turn. U-134 was actually refueled by U-170 with $42 \mathrm{cbm}(11,275$ gallons). She also received seven days' worth of rations, some spare parts for her metox (German radar) and medicines for her corpsman. Two hours later she disconnected the fuel line. U-134 proceeded on course to her next destination. Grid square DN10 was northeast of the Bahamas Islands, due east of Palm Beach, Florida.

The successful milch cow U-488 returned to Bordeaux July 10, 1943. U-tanker operations were elsewhere so perilous her reception was a heroes' welcome. Her next voyage was less successful. She was able to refuel only nine boats. Her third voyage was her last and was entirely unsuccessful. U-488 was sunk with all hands lost. ${ }^{79}$

\section{$\underline{28.6}$}

$\frac{28.6}{17.18} \mathrm{U} 537$ meldet Versorgung von $U 134$ aus $U 488$ am $26.6 .{ }^{80}$

June 28

\footnotetext{
${ }^{78}$ Kriegstagebuch U-134, final patrol.

${ }^{79}$ U Boat Tankers, p. 208.

${ }^{80}$ Kriegstagebuch U-134, final patrol.
} 
1718 Hours U-537 reports U-134 refueled by U-488 on June 26.

U-537 was an inbound boat. Her report is another example of communications security in practice. By reporting for U-134, she allowed U-134 to maintain radio silence as the boat approached its area for offensive operations. At the same time U-537 was reporting on her own status.

30.6

$\mathbf{2 3 . 5 0}$

$\underline{\text { June } 30}$

2350 Hours

\section{Von B.d.U.:}

Ab 1.7.08.00 Uhr "Amerika II" schalten. ${ }^{81}$

From B.d.U.

On July 1 at 8 am switch to "Amerika II" frequency.

This message is another concerning itself with communications. As the attack boat sailed westward from Europe, routine signals calibrations were made.

$\underline{6.7}$

11.45

July 6 1145 Hours
Von B.d.U.:

\section{Als Angriffsraum Gebiet zwischen DL 31, 67, DM 69,} DB 93 besetzen. ${ }^{82}$

From B.d.U.:

Take up battle stations between DL 31, 67, DM 69 and DB 93.

This signal reveals the mission of U-134. DL31 is a point in the Gulf of Mexico due west of Port Charlotte, Florida and due south of Panama City, Florida. DL67, the companion coordinate is Cancun, Mexico on the Yucatan Peninsula. DM69 is a point on the northerly coast of Cuba at Cabo Frites. An imaginary line drawn due west from this point (first traversing the Cuban landmass) includes the southerly coast of Cuba starting at Playa de Giron west past the Isle of Pines, and across the mouth of the Yucatan Passage, ending at Cancun. DB93 is a point at sea a hundred miles due east of Cape

\footnotetext{
${ }^{81}$ Kriegstagebuch U-134, final patrol.

${ }^{82}$ Ibid.
} 
Canaveral, Florida. An imaginary line run south from DB93 passes through the Bahamas Islands and meets point DM69 on Cuba's northern coast.

U-134 was ordered to attack shipping in the Florida Straits, the Yucatan Passage and Santaren Channel, three maritime passages of primary importance and bring war to the southern half of the Florida coast, the Bahamas and Cuba. The two major ports of Miami and Havana fell within her area of operations.

\section{$\underline{8.8}$}

\subsection{DD9475 Tiefangriff Lerwick, 6-8 Bomben und Beschuss ohne} Schaden. Treffer im Flugboot. $108 \mathrm{cbm}^{83}$

July 8

1920 Hrs DD9475 Attacked by a low flying seaplane using 6-8 bombs and gunfire without effect. We got good shots into the flying boat. 108 cubic meters [of fuel remaining].

Note before going ahead a typo made by the German transcriber of this entry in keying " 8 " vice 7. This combat encounter actually occurred July 7, 1943. We know because that same day the War Diary of United States Naval Air Station Bermuda records the following entry for July 7, 1943:

1415 Lieut. Soveral, P.P.C. of VP-201-P-3 made a radar contact which on investigation proved to be an enemy submarine. At 1418 visual contact was made and he approached the U-boat above scattered clouds. The sub remained surfaced and fired at the plane with deck guns. The starboard engine was hit and completely disabled. At 1422 the attack was made. The nearest bombs fell about 150 feet from the sub, due apparently to enemy fire which released the bombs in salvo rather than in rotation. The sub was undamaged and Lt. Soverel was forced to withdraw due to his disabled engine. The plane returned to base on one engine, after jettisoning all spare equipment. This attack took place at Lat. $27 \mathrm{o} 04^{\prime}$ N., Long. $59 \mathrm{o}-48^{\prime} \mathrm{W}^{84}$

\footnotetext{
${ }^{83}$ Kriegstagebuch U-134, ninth patrol.

${ }^{84}$ War Diary, Naval Air Station, Bermuda, July 8, 1943.
} 
German nautical address DD7475 corresponds to chart location Latitude 27 degrees 04 minutes North/Longitude 59 degrees 48 minutes West. Same time, same place.

The flying boat pilot was Lieutenant William Wolcott Soverel, a Princeton man who had joined the Navy the previous year. ${ }^{85}$ The seaplane was nearing the limit of its 420-mile range from Bermuda and was part of Navy squadron VP-201. These were twinengine P-3 Martin Mariners, aircraft with distinctive gull-shaped wings, armed with 50caliber machine guns and two sticks of four bombs each. Closing at 4800 feet on a radar contact at about 1410 by Aviation Radioman Third Class G. N. Levaklis, the Navy plane identified the U-boat and at three miles out dropped into a bombing run.

The U-boat opened fire with its two 20-millimeter anti-aircraft guns. The seaplane bow gun mount returned fire but the weapon jammed almost immediately. With open bomb bay doors and no covering fire, the seaplane pressed home the attack. At 400 yards the pilot ordered bombs away. Lieutenant (junior grade) Thomas J. Hitchcock had set the bombs for timed release in pattern. At that moment fire from the U-boat riddled the bomb bay, smashing the release mechanism and causing all eight bombs to drop at once in a cluster, three hundred yards short of the target.

The record of this sea-fight also contains unique photographic documentation. From the waist hatch Ensign Wade, one of the air crewmen, took a snapshot of the submarine as the plane flew past the U-boat at low altitude after its bombing run. The explosion of the bombs in one cluster just short of their target can be seen at the top of

\footnotetext{
${ }^{85}$ Interviews with the pilot's son Peter Soverel.
} 
the picture. ${ }^{86}$ Aircraft machine gun fire (from the tail gunner) stitches the water. The submarine deck gun crews are swiveling to port to continue firing at the plane. The damage to the flying boat's engine and bomb releases by the German anti-aircraft fire, causing her payload to drop prematurely and narrowly miss was good shooting on their part.

The seaplane was badly shot up in the exchange and reduced to one engine. Breaking off the engagement, the pilot returned to base. In a good example of emergency flying at wave level, Soveral managed to coax the crippled aircraft back across the four hundred miles of ocean and reached Bermuda late that afternoon. The photograph shows both submarine weapon systems engaged are clearly twenty-millimeter anti-aircraft machine guns, and both are located abaft the conning tower. Moreover, the bow of the U-boat is void of any deck cannon.

At this stage in the Battle of the Atlantic, the U-boats had removed these deck cannons. Initially useful for sinking damaged enemy ships, thereby conserving precious torpedoes for further attacks, the big deck cannon had gradually lost its effectiveness. Counter-attack from the air had become the critical concern of the U-boats, and the slowfiring single-shot anti-ship cannon was useless against that. By the summer of 1943 B.d.U. had replaced this dead weight in cannon and munitions, rearming the U-boats with additional 20-millimeter guns. ${ }^{87}$

This was not necessarily common knowledge to those opposing them, understandably so. The dramatic image of the surfaced U-boat firing coup de grace

\footnotetext{
${ }^{86}$ This dramatic combat photograph of a U-boat under attack has been widely circulated. The original resides in the photo archives of the Navy Historical Center, Washington, DC.

${ }^{87}$ Doenitz, Memoirs, p. 268.
} 
rounds into floundering merchantmen was the picture of the enemy that American sailors went to sea to fight against. It is important to this thesis that it points out the fact the U134 had no such cannon on its ninth patrol. We will be examine the combat with the airship K-74, whose crewmen reported hearing explosions in battle, attributing it to Uboat cannon salvos. This was impossible. The explosions were something else.

The U-boat report of the action closes with the cryptic entry "108 cbm." Boats commonly appended fuel reports in closing; this one indicates 108 cubic meters of diesel (about 29,000 gallons) aboard.

\section{8}

05.41 DM4926 Von U 134:

\section{Werde von Flugzeug angegriffen. ${ }^{88}$}

July 20

From U-134:

0541 Hrs DM4926 Attacked by an airplane.

Note the typographic error in the date/time group recorded by the German typist for this entry. The location DM4926 corresponds to just off the northeast coast of the Isle of Pines, Cuba. This would put U-134 exactly on station per her orders, at the southern boundary of her patrol area. Since the entry that follows predated the date of this entry and is proveably correct, it can only be pointed out that the date/time group here is in error, being off a digit as to month (" 8 " instead of 7, as was the previous entry) and day. Owing to this it is difficult to trace which allied aircraft from where spotted the U-boat off the Isle of Pines, but it had to have been between July 10, and July 19. If a standard cruising speed for the boat, uninterrupted, is taken into account, the boat reached DM4926 from DD9475 about July 15, 1943. We do know that she then turned back from Isle of Pines into the Yucatan Passage and was on station in the Florida Straits by July 18.

\footnotetext{
${ }^{88}$ Kriegstagebuch U-134, final patrol.
} 


\section{CHAPTER IV. - BATTLE AGAINST NAVY BLIMP K-74}

0531

Von 134:

19.7. DM5216 nachts von Marineluftschiff 5 Bomben und Kanonenbeschuss. Tauchzelle 5. Unterbriebezelle St.B und 4 St.B. beschädigt. Luftschiff abgeschossen. Viele Munitionsversager $2 \mathrm{~cm}^{89}$

0531 Hours $\quad$ From U-134

July 19 at DM5216 night attack by a Navy airship with five bombs and gunfire. Main ballast tank \#5, starboard quick diving tank, and starboard \#4 damaged. Shot down the airship. Many 2-centimeter ammunition misfires.

The message is historic in that it reports the only confirmable incident of combat between an airship and a submarine. For the sake of aviation and maritime history, as well as the local history of the Florida Straits of the Atlantic where it occurred, this combat will now be examined.

The evening of July 18, U.S. Navy Airship K-74 readied for departure at Naval Air Station Richmond, south of Miami, Florida. ${ }^{90}$ K-74, the 74 th of this class produced, had not been in the Navy inventory long. Built by Goodyear at its Akron plant to Navy specifications and under Navy supervision, her specifications Serial 30196, Goodyear envelope D-133, control car C-133. Two Pratt-Whitney engines were mounted port and starboard the car. Coming off the assembly line in Summer of 1943, the airship was commissioned by WAVE Aviatrix Lieutenant Joy Hancock and delivered to Naval Air Station Lakehurst July $2^{\text {nd }}, 1943 .{ }^{91}$ She was assigned to ZP-21 and flown to Naval Air Station Richmond, FL, a few days later. The assignment of July 18 was only her fourth combat patrol. The crew was made up from scratch, as was normal with airship

\footnotetext{
${ }^{89}$ Kriegstagebuch U-134, final patrol.

${ }^{90}$ Gulf Sea Frontier War Diary, July 18, 1943.

${ }^{91}$ Shock, U.S. Navy Pressure Airships II, p.20.
} 
operations. Because the flights were usually long, either all day or all night, air crewmen reporting for duty went up in whatever airship was available. Likewise, the crews were put together of whomever was available for duty. Nevertheless all of the crew had flown together on other airships on other patrols.

The blimp had a crew of ten men aboard and was armed with four five-hundred pound depth bombs. A 50-caliber machine gun with 500 rounds was mounted in the car above the pilot's compartment. ${ }^{92}$ A 45 -caliber pistol was in the tray under the pilot's seat. Just before departing the command pilot, Lieutenant Nelson G. Grills, his navigator, Ensign Darnley Eversley, and the co-pilot, Aviation Pilot First Class John Jandrowitz ${ }^{93}$ attended a preflight briefing at the Richmond Naval Air Station headquarters. Also present were the aviators of Airship K-32, with whom they would share the watch. Their mission was the night patrol of the Florida Straits.

At 1900 the airships departed from Naval Air Station Richmond. The ten personnel aboard were: Nelson G. Grills, Lieutenant, USNR, Airship Pilot and Commander; Darnley Eversley, Ensign, USNR, navigator; John Jandrowitz, Aviation Pilot First Class, USNR, co-pilot; Isadore Stessel, Aviation Machinist Mate Second Class, USNR; Jonathan L. Schmidt, Aviation Machinist Mate Third Class, USNR; Robert Herbert Bourne, Aviation Radioman Third Class, USNR; Rice, John F., Aviation Radioman Third Class, USNR; Gerrold M. Giddings, Aviation Radioman Third Class,

\footnotetext{
${ }^{92}$ U.S. Navy airship squadron ZP (Zeppelin Patrol) 21, Action Report, July 21, 1943

${ }^{93}$ Note for future researchers: Polish émigré John Jandrowitz later shortened his name to John Jan. John Jan continued a successful naval career, rising to Executive Officer of Lakehurst Naval Air Station in February 1961 . He was in that position when finally commended for his service in the K-74 night attack 18 years earlier.
} 
USNR; Garnet Eckert, Aviation Ordinance man Third Class, USNR; and John W. Kowalski, Seaman Third Class, USNR. ${ }^{94}$

All were volunteers or draftees. None were Navy Regulars.

The specifics of that patrol were that the K-74 would depart the mainland and patrol south by southwest from the starting point of Key Biscayne. The K-32 meanwhile would patrol south by west across Florida Bay, make a round turn over the Marquesas, and then patrol east to rendezvous with K-74 below Marathon. So as not to home on themselves and literally fly into each other, the two airships would break radio silence approaching Marathon. After establishing contact, the two airships would break off and retrace their steps. At about midnight July 18-19, K-74 encountered a radar contact at Longitude 23 degrees 59 minutes North/Latitude 080 degrees 49 minutes West. This is the same location as the German U-boat signal given as DM5216.

The U-boat message is terse. Yet the report is the longest of its messages and says a great deal. It describes being attacked with both bombs and gunfire [naval and aviation nomenclature frequently refers to machine guns as guns or cannon in describing them]. The U-boat reports serious damage. It states success in shooting down the airship. The message concludes by reporting many misfires of the ammunition for their 20-millimeter $(2 \mathrm{~cm})$ anti-aircraft guns. Despite some errors to the report, the salient points are clear: U-134 encountered an airship in combat, took and gave blows, and shot it down. Although impossible to have been attacked by so many as five bombs (K-ships only carried four), it nevertheless describes battle damage consistent with the effects of explosives. Damages to the diving tanks were structural damages to the hull below the

\footnotetext{
${ }^{94}$ ZP21 Action Report, July 21, 1943
} 
waterline, not likely to be caused by machine gun fire. The effects of machine gun fire were well known and understood. The U-boats were built armored against where machine gun fire would strike, generally the deck and conning tower. Machine gun fire's primary effectiveness was against the crewmembers topside. Damage to the superstructure below the waterline was rare and difficult. U-134 reports being attacked by both bombs and gunfire.

Turning to the American accounts of the incident we must first look at the overall situation at sea that night.

There was a degree of censure imposed on the American pilot and crew of the K74 in the aftermath of the combat. The attack was depicted as a rash and needless failure. That the attack was not entirely successful cannot be debated. The blimp was shot down and destroyed and one crewman killed in action. But before even assessing the results of the attack, the motivation for it must be examined. Military actions are taken in support and furtherance of basic military doctrines. When it is in accord with such doctrines the action is justified, whether the outcome is successful or not.

The pilot has always maintained that there were merchant ships in the area, that the U-boat appeared to be positioning itself to attack, and that it was the duty of the K-74 to defend against that by making its own attack. Both radiomen of the K-74 recollected in interviews that the night of July 18 , their radar made contact with two merchant ships that the K-74 overflew before encountering the U-boat. Since the mission of all the allied armed forces engaged in the Battle of the Atlantic was to defend the shipping upon which the outcome of the war depended, this consideration would justify the pilot and crew in their preemptive attack. 
It is easy enough to prove.

Every midnight at Seventh District Headquarters in downtown Miami the Commander, the Gulf Sea Frontier Summary of Days Operations was compiled of all shipping activity that day within its boundaries. All military and civilian shipping was reported, together with enemy submarine contact appreciations, aviation patrols and weather data. The report for July 18 notes the K-74 itself launching at $1909 .^{95}$ These secret reports declassified in 1997 record in detail the ship traffic, whether convoy or single ship, name and number of naval escorts, speed, location at time of report, destination and estimated time of arrival, air umbrella coverage and other pertinent details. A study of these summaries proves Lieutenant Grills and the crew of the K-74 to be correct that the U-134 was an immediate threat to certain merchant ships.

There were merchant ships transiting the Florida Straits the night of July 18-19 in close enough proximity to have been in jeopardy of attack by the U-boat. At this juncture a note concerning the whereabouts of the rest of the U.S. Navy is in order. Major naval operations were then being conducted around the Caribbean island of Martinique. The local island government was loyal to that of Vichy France and thereby a problem. Martinique was providing aid and comfort to the Nazis. On account of the proximity of the Allies at Antigua and Trinidad, U-boat visits were very low key. But aid and comfort was extended to them during nocturnal port calls. Wounded German sailors were being treated in the hospital. Fuel was made available to U-boats. The German embassy there was a safe haven for communications. But far more serious than these nuisance

\footnotetext{
${ }^{95}$ War Diary, Gulf Sea Frontier, July 18, 1943.
} 
collaborations were the implications for Allied strategy of the existence of substantial French military hardware being hosted by Martinique in its harbor. ${ }^{96}$

The allied war effort called ultimately for an invasion of France. It is charitable to characterize Allied relations with the Vichy government as poor. They bordered on belligerency. Influencing how the inhabitants of France would react to the inevitable introduction of hundreds of thousands of combat troops onto her soil was a matter of top priority. Complicating the matter was the French Resistance movement, the government in exile, was by no means united. Far less; it was difficult, fractious and splintered. Its titular head, General Charles De Gaulle, while only grudgingly accepted by many of his compatriots in the Resistance, was himself a challenging leader hardly a pawn to allied interests. ${ }^{97}$

The delicacy of the situation was underscored by the presence of a good part of the French Navy, including its aircraft carrier Bearn in the anchorage at Martinique. The battleship Jean Bart and a cruiser-destroyer squadron, all manned and ready for war were ranged beside her. Bearn, with a hundred American-built fighters and bombers on board, was a threat to the American coast itself. Turned loose against the Allies from Martinique with good leadership and proper motivation, the French squadron could have wreaked havoc and even tipped the very scales of war the U-boats were so heavily weighing upon.

To resolve it all, the bulk of U.S. naval forces in the Caribbean were collected about Martinique, ostensibly for sea trials. A Battle Group including the aircraft carrier USS Bunker Hill, the battleship USS New Jersey and cruisers USS Cowpens, USS

\footnotetext{
${ }_{97}^{96}$ Churchill and Roosevelt: the Complete Correspondence, Volume Two, p. 147

${ }^{97}$ Ibid, p. 231
} 
Baltimore and USS Chester were training off shore alongside transports loaded with invasion troops. Fortunately diplomatic negotiations to prevent bloodshed with the French had just concluded peacefully. A face saving capitulation by the island regime avoided the necessity of a pitched battle against the former ally. But the American ships, including destroyers, destroyer escorts and sub chasers had yet to return to their ASW stations. K-74 was going it alone that night.

The Summaries in the days before, during and after the fight between K-74 and U-134 reveal a comprehensive picture of the shipping activity in the waters around Florida and transiting both the Florida Straits and Yucatan Passage, and heading across the Gulf of Mexico to and from Galveston and Corpus Christi, Texas. Most of the traffic to and from Texas was in tankers, full or empty as the case may be. As many of the merchant ships as possible were under the escort of Sub Chasers, Yard Patrol Boats, Patrol Chasers and Coast Guard Cutters.

It can be seen that the Gulf Sea Frontier Summaries air operations sections reveal significant contributions by both airships and especially the Civil Air Patrol. On July 18, Navy fixed wing aircraft flew 460:15 flight hours on patrol and escort. Navy blimps logged 149:30 flight hours. Next day Navy airplanes logged 570:50 hours of flight time. Blimps logged 160 flight hours. At the time Navy airships accounted for a quarter of all Navy ASW mission there. ${ }^{98}$

Civil Air Patrol contributed remarkably. On July 18 the Army Air Corps flew patrol and escort missions totaling 72:42 flight hours. CAP missions logged 197:42 flight

\footnotetext{
${ }^{98}$ War Diary, Gulf Sea Frontier, July 18, 1943
} 
hours during the same period. ${ }^{99}$ The next day Army planes flew another 44:18 flight hours. CAP logged 180:36 flight hours. ${ }^{100}$ Unpaid civilian volunteers flew over 75 percent of Army missions and accounted for most of the Army presence in the air umbrella over Florida at the time. Most of the maritime traffic at sea enjoyed some protection by these escorts. Most, but not all.

Three ships passed unescorted through the Florida Straits that night, the SS Atlantic Coast, SS Settler and the SS Northumberland. ${ }^{101}$ The night was bright with almost a full moon.

The Northumberland was heading for the Panama Canal, covered by aircraft patrols from 0600 to dark out of Key West and San Julian, Cuba. At midnight her position was plotted at 24 degrees 51 minutes North/80 degrees 17 minutes West. The SS Atlantic Coast was an empty tanker out of New York bound for Galveston. Making 14 knots, she entered the Gulf Sea Frontier off Mayport at 0400. At midnight her position was plotted at 24 degrees 28 minutes North/79 degrees 50 minutes West. Aircraft from Walker Cay had an eye on the tanker from 0600 to dark making her way down the Florida gold coast. SS Settler was steaming 10 knots southerly for Key West without air cover. She had been sighted at $4 \mathrm{pm}$ on July 18 at 25 degrees 11 minutes North/80 degrees West, placing her in the midst of the Straits due east of Tavernier. Her plotted position at midnight was 24 degrees 31 minutes North/81 degrees 20 minutes west. $^{102}$

\footnotetext{
${ }^{99}$ War Diary, Gulf Sea Frontier, July 18, 1943

${ }^{100}$ Ibid, July 19, 1943

${ }^{101}$ Ibid, July 18, 1943.

${ }^{102}$ War Diary, Gulf Sea Frontier, July 18, 1943.
} 
SS Settler made Key West the next morning and was removed from the chart. SS Atlantic Coast also cleared the Straits and was positioned near the Dry Tortugas bearing northerly to follow the Gulf coast for Texas at the same time. Likewise Northumberland, then plotted about to enter the Yucatan Passage on its journey south to the Panama Canal. With those courses, headings and speed these ships in the minutes before midnight could have easily come within range of U-134. ${ }^{103}$ Her metox may have already acquired one, or two, or even all three as targets when the K-74 interposed herself. The justification for the airship's attack is there. U-134 was athwart the Straits at the same time as three merchantmen, including a tanker, were transiting.

In the event, the K-74 picked up on radar the unidentified object that was the submarine at 2340 at a range of eight miles. ${ }^{104}$ Closing in on the radar blip at 500 feet the airship sighted a wake below them. The pilot maneuvered so as to keep the airship down moon from the contact and trailed up the wake. Within a few minutes the airship sighted the submarine itself. All hands saw the submarine, observed to be running on the surface on a heading of 220 degrees true north. ${ }^{105}$ This course would take her to the merchant ships the blimp had flown over earlier. The pilot brought the airship to battle stations. There was some conjecture among the crew as to the identity of the submarine, whether it was the enemy, or an American submarine on maneuvers. ${ }^{106}$ The pilot remained within cloud cover and gave a wide circle to the sighting. Visual was lost.

\footnotetext{
${ }^{103}$ Ibid, July 19, 1943.

${ }^{104}$ ZP21 Action Report, July 21, 1943

${ }^{105}$ Ibid.

${ }^{106}$ Author interviews with the pilot Nelson Grills.
} 
The pilot again circled, this time in a wider arc and returning to position down moon, the submarine was again sighted. This time the airship lay off down moon and kept her in sight.

At this point the airship pilot determined to attack. He ordered the airship gunner Petty Officer Eckert in the gun berth overhead to hold his fire until and unless fired upon. He explained aloud that if the identity of the submarine were American, it would not open fire. In which case the airship would fly over it and signal recognition. Eckert responded affirmatively. The pilot asked the bombardier squatting at the bombsight window just before him if he was ready. The bombardier Petty Officer Stessel responded affirmatively. The airship went to 250 -feet altitude and commenced a bombing run. ${ }^{107}$

Almost simultaneously the submarine spotted the airship. The airship crew observed yellow-orange lights begin to flash aboard the submarine indicative of gunfire tracer rounds. An incoming round punctured the Plexiglas windshield of the airship. The airship machine gunner returned fire. At about the same moment the submarine was observed to turn portside, thus presenting the slimmest target to the oncoming blimp. The airship starboard engine nacelle was observed to receive battle damage, and display sparking and flaming. Engine rpm's abruptly decreased, throwing the airship into drift. The airship machine gunner expended an entire belt of ammunition, reloaded and continued firing. ${ }^{108}$

Now the submarine tracers became erratic and then ceased altogether for several moments. The submarine later reported many ammunition misfires. In addition, surfaced in their operational area at night, the U-boat would have had at least four watch

${ }^{107}$ ZP21 Action Report, July 21, 1943.
${ }^{108}$ Ibid. 
standers and the gun crews topside. Also, the Watch Officer, if not the Skipper himself, would be present. With at least these nine sailors on deck it is not impossible the airship machine gunner inflicted casualties. Numerous ricochets were reported seen striking off the U-boat hull. Enemy personnel may have been forced to take cover behind the bridge combing or even been hit. Neither U-boat gun mount was armored. The submarine made no casualty report later, but Eckert's machine gun fire clearly was on the target. Fire from the U-boat temporarily ceased.

Soon after, the airship pilot commanded bombs away. The bombardier appeared not to hear him. With the airship by then practically closed on the target, the pilot repeated the order. ${ }^{109}$ So near was the airship that Eckert ceased firing, as the machine gun mount would depress no further and Eckert himself could no longer see the target below. ${ }^{110}$ The anti-aircraft gunfire of the U-boat now resumed. The range was pointblank and deadly. The airship went out of control. It assumed the attitude of standing on its tail; that is, it swung perpendicular to the ocean with the nose of the blimp pointing skyward. The crew was thrown about the airship cabin as it began to gain altitude, rushing straight up. It rose to an altitude of approximately 1,000 feet, accompanied by severe shaking of the cabin. The airship threatened to invert (flip over).

To regain control the pilot pulled the releases jettisoning the two outboard fuel slip tanks. ${ }^{11}$ These two 380 pound fuel tanks separated and fell away from the underside of the gondola without incident. This loss of weight momentarily renewed buoyancy. The airship stabilized in a horizontal attitude. It began to descend. The anti-aircraft fire

${ }^{109}$ ZP21 Action Report, July 21, 1943

${ }^{110}$ Ibid.

${ }^{111}$ ZP21 Action Report, July 21, 1943 
had done severe damage to the airship's outer envelope, inner helium-filled ballonets and sinews of cabling. Petty Officer Schmidt leaned out the engine service hatch with a fire bottle and extinguished the blaze in the starboard engine nacelle. ${ }^{112}$ The port engine continued to function but the rudder and tail elevators appeared to be shot away. The airship was going down tail first and unresponsive to control.

The U-boat continued firing. The airship envelope continued to be riddled by the submarine's anti-aircraft guns as it descended. The pilot and navigator hastily agreed to make for North Elbow Cay. ${ }^{113}$ Grills ordered the crew to jettison everything possible to stay aloft. A few toolboxes and bits of spindle drift were tossed overboard. The crew braced for emergency landing at sea.

During this time Radioman John Rice retrieved a simple three-letter acronym from the logbook he habitually carried on duty in his shirt pocket. His counterpart at the key, Radioman Robert Bourne began sending in clear this three-letter acronym "OFU." It was a signal unique to the squadron with the letters standing for "Urgent - Fired on." This simple mayday had been created by the Squadron commander as a quick means of signaling distress in the event of contact. Bourne sent the signal a total of sixteen times in the short time during which the airship was descending. ${ }^{114}$ Although naval authorities for his unorthodox invention later criticized Lieutenant Commander Cope, the ZP-21 Commander, in the event it probably saved the lives of the K-74 crew, as there was no time to write, code and send the format message regulations approved in such a situation. This simple message was received by the K-32, the other airship on patrol that night.

\footnotetext{
${ }^{112}$ Ibid.

${ }_{113}$ Author interviews with Nelson Grills.

${ }^{114}$ Action Report, July 21, 1943
} 
Radioman J.J. Turek aboard K-32 took the initiative to report the message to NAS Richmond, providing a first and timely alert to the contact. ${ }^{115}$ Others probably picked up the K-74's transmission, but could make nothing of it.

We may assume that the enemy submarine also monitored the K-74 transmissions. While they could have had no way of telling what the exact verbiage of the signal meant, they would almost certainly have concluded it was a contact report, and reacted accordingly. In such circumstances having little further to gain by continuing to prosecute hostilities, it was standard operating procedure to clear the area.

As the airship neared the water the starboard engine turned over. The tail of the airship touched the water. The propeller blades sliced into the sea and cut out. The blimp car began to settle onto the water. Petty Officer Rice looked at his watch. The time was $2357 .{ }^{116}$

\section{Did the K-74 Drop Bombs?}

In the aftermath of the battle against the U-134, a basic mis-assumption made at the time remains in folklore to this day: the erroneous belief that the K-74 bombs malfunctioned -- that there was mechanical error of the bomb release mechanism, and possible operator error on the part of the bombardier. The bombardier was killed during the incident and left no testimony. The fallacy came from two sources:

1) The surviving crewmen reported in the after-action reports that no bombs were dropped. They reported hearing explosions at two points during the incident. ${ }^{117}$ First, they heard explosions during the combat. These they attributed to the

\footnotetext{
${ }^{115}$ ZP21 Action Report, July 21, 1943.

${ }^{116}$ Ibid.

${ }^{117}$ ZP21 Action Report, July 21, 1943.
} 
U-boat deck cannon. Second, they reported hearing two weak submerged explosions emanating from where the blimp wreckage had settled just before they were rescued early the next morning. ${ }^{118}$ No source for these explosions has ever been attributed.

2) The blimp pilot reported that after the blimp splashed down and the crew abandoned ship, he swam back into the blimp car to retrieve the pistol. He noticed the bomb levers were in the safe position, indicating unfired bombs. ${ }^{119}$ At the time it was known that the bomb releases on the K-ships, of 1921 Army vintage, were prone to malfunction in that if the releases were not pulled with a specific twist of the lever at mid-stroke they would not release the bombs.

Not considered at the time was that these release levers also had a tendency to slide back to the safe (unfired) position, or that the mechanism had two sets of levers. If only one set of bombs were released, the other levers would naturally be found in the unreleased position. Not to mention that it was a half-swamped compartment at midnight in the middle of the ocean just minutes after a battle and crash landing.

It is difficult to determine why years later the naval historian Admiral Samuel Eliot Morison did not include these facts of the matter when publishing his multi-volume Operational History of the United States Navy in World War II in the nineteen-fifties. By then Gordon Vaeth's discovery of the captured U-boat logs with U-134's report of battle damage from depth bombs was known within the small and understandably concerned airship community of the Navy. Morison's Division of Naval History in Washington also knew it. The K-74 incident was raised by his own office in a remarkable exchange of four letters in autumn of 1952.

\footnotetext{
${ }^{118}$ Ibid.

${ }^{119}$ Ibid.
} 
On September 18, 1952, Philip K. Lundeberg, the assistant to Morison, wrote on Division of Naval History letterhead to Alfred Cope, the former ZP-21 Squadron Commander. Cope was still on active service at the time, then serving as Commanding Officer of Naval Air Station Lakehurst. Lundeberg (who was himself a Naval Reserve Captain) indicated that in preparing a study for Morison's second volume, he was examining the records of the shooting down of K-74. Lundeberg requested from Cope clarification as to why Grills had gambled on attacking a surfaced U-boat. He asked whether squadron doctrine had motivated him. ${ }^{120}$

Lundeberg's letter clearly indicates the Division of Naval History knew of Gordon Vaeth's discovery. Lundeberg stated having ample information from American and German documents. He identified the submarine by hull number. He named its commanding officer, Brosin. He mentioned the seaplane it had previously engaged; and he referenced battle damage inflicted by the K-74's heavy strafing fire causing it to retreat. This information could have only been gleaned from the U-134 reports, which included reporting damage from bombs.

Commander Cope contacted the former pilot Nelson Grills about this inquiry.

On October 2, 1952, Grills wrote in reply to his former commander. He thanked Cope for contacting him, and expressed that he had always felt that his crew and squadron had not been dealt with fairly. He referenced Vaeth's discovery, stated his failure to understand why Vaeth's findings had not been made public, and he requested recall to active duty to complete the story of the K-74. ${ }^{121}$

\footnotetext{
${ }^{120}$ Lundeberg to Cope, September 18, 1952, author's papers.

${ }^{121}$ Grills to Cope, dated October 2, 1952, author's papers.
} 
On October 17, 1952, Cope wrote Lundeberg. He quotes almost the entirety of Grill's letter of October 2, 1952, excepting only the salutatory and complimentary closing. Cope states he twice recommended the pilot for meritorious award, being turned down both times. Cope further expressed his continued belief that pilot and crew had performed in an outstanding manner. Further, he wrote "Today, I am none too sure the bombardier did fail to release his depth charges." He reiterates specific mention of Vaeth's discovery that the U-boat reported several explosions. He answers Lundeberg's query directly, commenting that ZP-21 battle policy was along the line of aggressive action. In closing he recommends that Grills' request for recall be approved and that he be ordered to report to Lundeberg at the Division of Naval History. ${ }^{122}$

On October 27, 1952, Lundeberg wrote back. He thanked Cope for his interest and for contacting Grills. Lundeberg thanked Cope for his clarification that the attack was in accord with squadron policy. He apologetically explained that their office did not concern itself with pressing for merited awards, remarking, "which certainly appear justified in this instance." Lundeberg points out that Morison's Operational History was officially designated "unofficial", but that "Commander Grills may stand assured that his conduct will receive historical recognition.” He indicates Grills request for recall would be almost certainly unnecessary and impossible, being outside the purview of their office. He concludes that a brief written account would be sufficient for Morison's history. ${ }^{123}$ Morison's history was published the next year. Volume Two, page 194, contains an account of the combat. It mentions that the pilot violated lighter-than-air doctrine which forbade bombing runs on surfaced submarines, but states the pilot of K-74

${ }^{122}$ Cope to Lundeberg, October 17, 1952, author's papers.
${ }^{123}$ Lundeberg to Cope, October 22, 1952, author's papers. 
"bravely bore in," with the thought of protecting the merchant ships in the area as uppermost in his mind, but added the erroneous assertion, "Then, by a sad turn of fate, the long disused bomb release gear refused to function." ${ }^{24}$ Morison's "unofficial" history affirms the fallacy no bombs were dropped and set that mistake in stone.

It is impossible to know why Morison's account contains this inaccuracy. Any student of history will at some point meet with Morison's brilliance; his thorough, prodigious work and vast contribution to the field of history. His virtues are many and great; vision, sacrifice, patriotism; even courage under fire. There is no explanation for the inaccuracy. It was small and unimportant, except to a dead bombardier and a handful of others. But inaccurate it was. Perhaps the historian was not acquainted directly with Lundeberg's findings. Or perhaps they came too late to change things. Book publishing in the 1950's was still primitive. Months of lead-time between galleys and finished publication were often required. The split second corrections of computerized writing where unheard of. For reasons unknown, Morison's history was published with the inaccuracy that no bombs were dropped.

Yet if public knowledge was thwarted in the matter, there remained the official record to redress. The interests of the pilot and the surviving eight crewmembers of the K-74 continued to percolate through the system. The co-pilot John Jan ${ }^{125}$ remained in the Navy and pressed his claim. In 1960 the Navy acted.

In arguing for historic recognition of the discrepancy in Rear Admiral Morison's conclusion in the matter, the action of the Navy in 1960 has already done so as a matter of record. The Board for the Correction of Naval Records then awarded the

\footnotetext{
${ }^{124}$ Morison, Operational History of the U.S. Navy in World War II, Volume Two, p. 194.

${ }^{125}$ See page 97 , footnote 70 .
} 
Distinguished Flying Cross to the Command Pilot of the K-74, Nelson Grills. The eight surviving members of the crew of the K-74 were awarded the Navy Commendation

Medal. The covering letter from the Chief of Naval Personnel to the surviving crewmembers reads as follows:

1. The Board for Correction of Naval Records has recently reviewed correspondence relative to the attack against an enemy submarine on the night of 18-19 July 1943 by the United States Airship K-74. As a result of this review, the Board recommended that you and other members of the crew be commended for your action on this occasion. The Secretary of the Navy approved the recommendation on 13 October 1960.

2. The Chief of Naval Personnel takes pleasure in forwarding, with his congratulations, a Secretary of the Navy Commendation in recognition of your heroic achievement during the action referred to above.

\section{//ss// A. Christopher}

By direction ${ }^{126}$

With the letters were delivered the medals and citations themselves. The award

citation in three words, and depth bomb, acknowledges that the bombardier acted

correctly and did hit the target, as follows:

CITATION:

"For heroic achievement on the night of 18-19 July 1943, while serving on board the United States Navy Airship K-74, during an attack against a surfaced enemy submarine in the Straits of Florida. When the enemy submarine opened fire upon the K-74 with $20 \mathrm{~mm}$ guns, (CREWMEMBER NAME) participated in a low-altitude, machine gun and depth bomb attack by his craft, which inflicted damage upon the submarine and caused that vessel to disappear. The K-74 crash-landed in the sea without injury to any of the crew. (CREWMEMBER'S NAME) courage, skill, and devotion to duty in the face of hostile gunfire, were in keeping with the highest traditions of the United States Naval Service.

\section{//s// William B. Franke Secretary of the Navy ${ }^{127}$}

\footnotetext{
${ }^{126}$ Bureau of Naval Personnel letter PERS-G251-ehw, serial 55183 77, dated Dec. 7, 1960.

${ }^{127}$ Secretary of the Navy Letter of Commendation, Oct. 13, 1960.
} 
By reconstructing the U-boat's cruise prior to the combat, we know this submarine had no deck cannon. The explosions heard could not have been that.

The blimp went out of control after its machine gunner lost sight of his target. The airship had to have been almost directly overhead. (At this point the airship careened out of control, rising abruptly by the nose in a straight up attitude.) The release of the two 500-pound bombs the split-second preceding its sudden rise would certainly have provided impetus to this abrupt movement. Likewise, the extreme attitude the gondola assumed would have masked the crew from noticing the bouncing sensation caused by the release of the weight of the bombs. A horizontal blimp releasing bombs always caused the airship to buoy upwards. This simple aerodynamic phenomenon was a sensation all airship crews were familiar with from experiencing bombing practice.

To regain control the pilot released the two 380-lb fuel slip-tanks, which plummeted into the sea.

This thesis ventures that both the K-74 and the U-134 were mistaken. The bombardier did drop a pair of bombs. They went straight down and hit the target, exploding in close proximity to the U-boat at the depth they were set to, fifty feet. Those were the explosions heard by the Americans. Those two bombs, and the two fuel tanks that were jettisoned next, made up the 5-bomb attack the submarine reported.

The two weak explosions next morning were the other two bombs. These were never released. Set for a depth of 50-feet and still attached to the blimp, they went off next morning as the blimp car wreckage settled to that depth. The explosion was weak because the ordnance had been submerged for eight hours. Invasive saltwater degraded the charge. Perhaps only the detonators alone went off. 


\section{Aftermath of the Battle}

It was midnight when the airship splashed. The engine propeller knifed into the water and came to a stop. The impact was gentle; the blimp floated down. Grills tossed the lead weighted satchel with the classified encryption data and charts out the window into the sea. He commanded abandon ship.

The crew hastily tossed out the airship life raft. The life raft tethering line was tossed out along with it. The life raft began at once to inflate and quickly floated away. Without the line to hold it, the life raft was gone in moments. ${ }^{128}$ With the car of the blimp awash, the crewmembers went into the sea in their lifejackets. Bourne used his pocketknife to slice his way out through a canvas patch panel. ${ }^{129}$

The ten men sorted themselves out and clustering about the sinking airship car. The thought occurred to them that the enemy submarine might come alongside to seize them as prisoners of war. Grills sloshed back inside the gondola for the pistol under the seat. In the darkened half-submerged airship car he was unable to locate the weapon. Losing his bearings, he re-exited the car opposite the rest of the crew. The current swept Grills from the sinking airship. Managing to compose himself at some distance from the $\mathrm{K}-74$, he found it impossible to reach it again. His shouts went unanswered. With no alternative, he determined to strike out alone for the Florida Keys. The swim was approximately twenty nautical miles from his position. ${ }^{130}$

The rest of the crew, noting Grills' failure to return, clung to the airship, which was gradually settling into folds about them. It would take the entire night for the airship

${ }^{128}$ ZP21 Action Report, July 21, 1943.

${ }^{129}$ Interviews with Bob Bourne.

${ }^{130}$ ZP21 Action Report, July 21, 1943. 
to deflate and sink, so afforded a bit of safety for the time being. One group of five sailors; Eversley, Stessel, Jandrowitz, Bourne and Rice collected themselves about the stern tailfins of the airship that offered surfaces they could half-drag themselves onto and rest. Stessel the bombardier was nauseated from swallowing saltwater and agitated by his inability to swim. He had also gashed his leg against the bulkhead in exiting the car. Likewise, one of the two air pockets of his life jacket had been perforated. ${ }^{131}$ Jandrowitz is reported as providing primary assistance to the dispirited Stessel. They remained in the vicinity of the airship throughout the night.

The other four men; Eckert, Schmidt, Giddings and Kowalski swam away from the airship, under the mistaken apprehension that the U-boat might be still in the vicinity. Wind on the deflating airship blew them further apart. By daybreak the two groups were 1,000 yards apart. ${ }^{132}$

The most immediate response to their distress signal was by the K-32. This airship received the signal and raised the radio room at the Richmond Naval Air Station, which scrambled for an appreciation of the mayday. K-32 broke off its patrol and headed for the scene. Richmond meantime contacted the ZP-21 Squadron Commander. Commander Cope was at the time staying at the summer home of wealthy industrialist R. J. Grace, in the Miami suburb of Coconut Grove. (Grace's son was a pilot in the squadron and the tycoon had opened the house to the Navy.) Cope was roused by telephone. $^{133}$

${ }^{131}$ Ibid.

${ }^{132}$ ZP21 Action Report, July 21, 1943.

${ }^{133}$ Ibid. 
The squadron commander worked the telephone for the next few hours. He closed down his base and issued orders readying more airships for dispatch. He conferred with Gulf Sea Frontier Headquarters in downtown Miami. Then using the Grace family car, he drove to the nearby Coast Guard Dinner Key seaplane station in Coconut Grove to commandeer an aircraft. Commander, Gulf Sea Frontier sent out his own confidential signal \#190552 summoning the Navy to battle. ${ }^{134}$ The closest warship available was USS Dahlgren (DD 187), moored at Key West.

USS Dahlgren was an old four-pipe destroyer from World War One, one of the same class as those earlier turned over to the British. Dahlgren was now serving as the training ship for the Navy Sonar School, teaching the basics of this wartime technology to class after class of sailors, before their assignment to the front lines of the fleet. She was tied up to Clyde Mallory Dock. In absence of shore power, \#2 boiler was in operation for auxiliary power. At 0300 she was ordered to get up steam. The fires were lit off under \#4 Boiler, her lines were singled up and all preparations made for getting underway. Boiler \#4 was cut in onto main steam at 0310. At 0317 USS Dahlgren cast off and was underway. The navigator was on the bridge. Captain Curtis had the conn. Steaming at 18 knots, USS Dahlgren passed the Double Headed Shot Cay lighthouse at 0640. At 0828 a Coast Guard plane was sighted. ${ }^{135}$ The aircraft was a two-seater Grumman J4F Widgeon seaplane that ZP-21 Squadron Commander Al Cope had commandeered and launched from the Coast Guard Dinner Key seaplane station in Coconut Grove.

\footnotetext{
${ }^{134}$ USS Dahlgren, deck log, July 19, 1943.

${ }^{135}$ USS Dahlgren, July 19, 1943.
} 
At about 0745 this seaplane had located the now submerging blimp and sighted the nine survivors in the water nearby in two groups. They did not drop a life raft. For Cope and another observer to fit in the cramped space behind the pilot and co-pilot, the aircraft's emergency life raft had been left behind. ${ }^{136}$ A rising chop to the sea prevented the seaplane from landing. Instead the aircraft made radio contact with USS Dahlgren fifteen miles distant. After buzzing the sailors to demonstrate to them they had been sighted, the aircraft flew to Dahlgren to bring her to the scene. They were almost too late.

By 0800 the airship was entirely submerged. Both groups of airship sailors had become widely separated from each other. They reported that at about this time they heard two muffled undersea explosions in the vicinity of the sunken airship. These sounds were of negligible concussive value and neither endangered the men or roiled the otherwise rising sea state.

Both groups now saw the fins of sharks in the water, gradually coming closer. With the last of the airship tailfin remnants gone under water, the group that had stayed with the airship lost its cohesion. Stessel, in a half-deflated life jacket, sea sick, bleeding and exhausted; would not or could not keep up with the others, whose own efforts to assist him were flagging from exhaustion and the rising sea. Wave action broke up the group and Stessel was soon about fifty feet from the others. They called to him to rejoin them.

A shark was observed making for the man. Stessel was observed to go underwater and disappear. Then he reappeared momentarily, with blood over his head

${ }^{136}$ ZP21 Action Report, July 21, 1943. 
and shoulders and agonized visage. He disappeared under water. The other four drew themselves together back to back and having three knives among them made what preparations they could to defend themselves. Sharks approached the group but made no further attacks at this time. ${ }^{137}$

About 0945 USS Dahlgren arrived. Despite the danger of inadvertently pulling the survivors into the ship's wash, the destroyer came directly alongside the group, apparently recognizing the immediate danger from the sharks. Rifle and Thompson submachine gun fire was directed at the sharks. Ship's Company suspended from the Jacobs ladder amidships collected the survivors and helped them aboard. ${ }^{138}$

Simultaneously Dahlgren spotted the other group of four. Dahlgren's motor whaleboat was launched to their rescue. Again, Ship's Company drove off nearby sharks with small arms fire. The second group of K-74 survivors was then rescued. ${ }^{139}$

They were picked up at 23 degrees 58 minutes North/80 degrees 47 minutes West. Aboard Dahlgren the medical officer examined the eight. Bourne went to sickbay with first-degree fuel burns on his chest and back. Another final object was sighted 2000 distant at 0957 . The motor whaleboat investigated and brought onboard at 1017 a last item: one empty life jacket of the same type used by the survivors of the K-74. ${ }^{140}$ There is no way to determine whether that life jacket was Stessel's, a spare from the K-74, or unrelated flotsam.

With the survivors, except for Grills, accounted for, USS Dahlgren started from the oil slick of the K-74 a search pattern for the last survivor, and the enemy. About 1347

\footnotetext{
${ }^{137}$ ZP21 Action Report, July 21, 1943.

${ }^{138}$ USS Dahlgren, July 19, 1943.

${ }^{139}$ Ibid.

${ }^{140}$ USS Dahlgren, July 19, 1943.
} 
Coast Guard Patrol Craft 464 and Coast Guard Patrol Craft 466 joined her. USS

Dahlgren broke out the unit guide pennon, with the patrol craft forming the line at 3,000 yard intervals. They had been diverted to the scene from patrolling the Cuban coast. At 1545 they were reinforced by the brand-new destroyer USS Reuben James. She was named in honor of the Reuben James that had been torpedoed and sunk in action before war was declared. ${ }^{141}$ United States Navy Sub Chaser 511 and Sub Chaser 657 arrived soon after.

Meanwhile the K-46 airship had arrived overhead to participate, and was soon joined by the K-32, which had returned to Richmond at the conclusion of the night's patrol, and been turned around and launched again under the command of the Squadron Executive Officer, Commander Spicer, USN.

The searching ships were keyed for action. At 1717 USS Reuben James reported contact. At 1737 USS Dahlgren also got contact. At 1741 the Group went to general quarters. In developing an appreciation of the contacts, that of USS Reuben James was classified as non-submarine. That of USS Dahlgren was classified as a misreading of the wake of $P C 464$. At 1835 the group secured from general quarters. ${ }^{142}$

Sub Chaser 511 came alongside to receive the K-74 survivors for further transfer to Naval Station Key West. While this evolution was underway, the K-32 airship reported the sighting of the ninth survivor about $12 \frac{1}{2}$ miles from the group. With daylight fading, the K-32 had been making a last sweep for the day before returning to base when Petty Officer Max May, USNR, the rear lookout spotted an object several

\footnotetext{
${ }^{141}$ See page 24.

${ }^{142}$ USS Dahlgren, July 19, 1943.
} 
thousand yards distant. ${ }^{143}$ Returning to investigate, the airship discovered the object to be Lieutenant Grills, the pilot of the K-74. The airship determined the man was still alive and hovered overhead.

Subchaser 657 diverted to the rescue and USS Dahlgren sent its medical officer by motor whaleboat to attend him. Grills was dehydrated, dazed and severely sunburned from exposure, but otherwise sound. The back of his neck was badly lacerated from constant wear of the collar of his life jacket. Grills reported that once separated from the rest after the crash landing of the airship he had determined to strike out on his own, attempting to swim the twenty miles or so to the Florida Keys. During his 19 hours in the water he covered about half the distance before his efforts gave out. He reported being accompanied by sharks much of the time. These swam close by but fortunately did not attack. $^{144}$

After treating the last survivor, the medical officer returned to USS Dahlgren. Subchaser 511 and Subchaser 657 broke off for Key West with the survivors of the K-74. The two vessels operated darkened on reciprocal zig-zag courses for mutual support in case they encountered the enemy. They arrived at Key West about midnight without incident.

USS Dahlgren and the rest continued to hunt for the submarine, closing up the line to 2,000 yard intervals. During this time they were joined by three destroyer escorts: USS Brennen (DE 13), USS Edgar G. Chase (DE 16), USS Andres (DE 45), and Patrol Craft 613. ${ }^{145}$ Moving north of Cay Sal Bank, the group continued to beat up the Florida

\footnotetext{
${ }^{143}$ ZP21 Action Report, July 21, 1943.

${ }^{144}$ ZP21 Action Report, July 21, 1943

${ }^{145}$ USS Dahlgren, July 19, 1943.
} 
Straits looking for the U-134. At 0300 a confidential signal from Commander, Gulf Sea Frontier redirected their efforts south, ordering them to sweep the area northeast of the Dog Rocks. ${ }^{146}$

The course change by the battle group was in response to the submarine contact report by Ventura bomber PV-1 of Squadron 132.

${ }^{146}$ USS Dahlgren and Gulf Sea Frontier, July 20, 1943. 


\section{CHAPTER V. - RETREAT FROM BATTLE}

\subsection{DM2925 Von U 134: \\ Erneut durch Flugzeug angegriffen. Batterieschaden. ${ }^{147}$}

0603 From U-134: Longitude 24 degrees 10 minutes North/Latitude 79 degrees 40 minutes west.

Another attack by an aircraft. Battery damaged.

The next report of the U-134 is logged without a date. Nevertheless, we can determine it concerns events of July 20, 1943 the day after the blimp attack, by referencing the next message of U-134 on July 29. This signal reiterates the date and location of the previous message. Moreover, cross-reference to the American reports confirms the message is about activity July 20. Specifically, that night the U-boat was attacked again. This time it was by a Ventura bomber from Key West.

As a result of the engagement of July 18-19, the entire Gulf Sea Frontier Command was standing at heightened alert. In addition to the surface group formed up on USS Dahlgren to hunt for the enemy, as many air patrols as possible were being mounted. One such search mission by Squadron VP-132 took off from Boca Chica, Key West at $1924 .^{148}$

Ventura Bomber PV-1, commanded by Lieutenant J. C. Lawrence had a crew of five; co-pilot, navigator, tail gunner/tunnel lookout, radar operator and radioman. PV-1 was armed with six depth bombs. The bombs were MK-47 Torpex, fuzed to go off at 25 feet depth. PV-1 spent the next three hours conducting radar sweeps at 3000 feet over Santaren channel. There was a full moon and scattered clouds. The sea state was calm, with scattered thunderheads and electrical activity. At 2320 the aircraft entered a mild

\footnotetext{
${ }^{147}$ Kriegstagebuch U-134, final patrol.

${ }^{148}$ Bombing Squadron 132, Action Report, July 21, 1943
} 
thunderstorm. Losing altitude to 2200 feet, PV-1 emerged on a westerly course at 2323 . Almost immediately the tail gunner reported sighting a wake astern in the moon's path. The location was latitude 24 degrees 10 minutes North/Longitude 79 degrees 40 minutes West. This corresponds to kriegsmarine grid DM2925; the submarine U-134. Its path was crossed again.

Analysis indicates the submarine was possibly in the act of surfacing when sighted. The submarine was not picked up by the aircraft's radar sweeping ahead of it. Although it is possible that the lightning was affecting the radar, (or the radar operator was inattentive), more likely the submarine was not painted onscreen because she had not broached surface before the radar beam passed overhead. Reinforcing this is that the radar did pick up the contact after the visual sighting. The visual spotted by the tail gunner may have been a result of the size of the wake itself. The wake generated by a surfacing submarine is more pronounced by far than the wake of a submarine already trimmed to surface cruising. Whether sighted just coming up for air, or surface cruising in the course of its retirement from the scene of the previous engagement against K-74 (her movement to DM2925 is clearly a retrograde away from the sea lanes of her combat area); U-134 was sighted. (See appendix for after-action drawing).

PV-1 moved away and circled back to pick up the trailing edge of the wake and flew parallel to it to follow up the wake. The pilot trailed to port, so as to keep the target between him and the moon. The object was sighted ahead at 2326 and subsequently picked up on radar, distance three miles. The sighting was evaluated as a submarine, fully surfaced, making about eight knots, and heading out of the moon's path and towards an area of storm clouds just ahead. The plane captain chose to attack immediately. 
No flares were deployed to prevent prop glare from affecting the pilot. The bow camera was left off because of the poor contrast looking down the moon path. Strafing was avoided to maintain the element of surprise. ${ }^{149}$ When parallel to the submarine the PV-1 turned to it and dove to the attack. The pilot aimed on the base of the forward edge of the U-boat conning tower. The six bombs were released set to space 60 feet apart and the aircraft pulled out directly over the submarine at fifty feet. The tail gunner observed two explosions and waterspouts; one about 70 feet out from the target, and another about ten feet short of the target. The angle of the climb then prevented further observation and contact was lost. ${ }^{150}$

PV-1 leveled off at 900 feet, turned back and returned to the point of the attack at 2330. Nothing was observed. The bomber circled on station until low on fuel. PV-1 broke off at 0015 . The relief aircraft that had been vectored to the spot arrived at 0100 . No further sign of the enemy was reported.

29.7.

03.00

DO1627 Von U 134

Gehe DP Reparatur. Ausfälle vom 19.7.20. nachts von sehr schneller Landmaschine DM 2925 überrascht. 3 Flibos unter Vorschiff. Batterie 2, Rohr 4 ausgefallen. Standsehrohr beschädigtränkt klar. $71 \mathrm{cbm}^{151}$

July 29

0300 Hours

From U-134:

Must fall back to mid-Atlantic for repairs. Damage from the attack of July 19 and night of the $20^{\text {th }}$ surprise attack by fast land airplane at DM2925. That aircraft put three bombs under my foc'sal. Battery No. Two and torpedo tube No. 4 are out of service. Our attack periscope only has

\footnotetext{
${ }^{149}$ Bombing Squadron 132 Action Report, July 21, 1943.

150 Ibid.

${ }^{151}$ Kriegstagebuch U-134, final patrol.
} 
partial visibility. 71 cubic meters (18,900 gallons of fuel) remaining.

The U-134 had retired entirely from her attack space. Her position before encountering the blimp was in the middle of the Florida Straits, within a hundred miles from either of the two important maritime centers of Miami and Havana. She sustained the second attack by the PV-1 while on station too, albeit in retrograde from the first encounter. Now she was out of her operational area and the Caribbean altogether, north of Puerto Rico in the blue waters of the Atlantic. And she was reporting she had to retire still further on account of her battle damage.

Damage to the submarine batteries was a grave matter. Weakened batteries could prevent a U-boat from submerging. Or if it could submerge, it could lack the electrical plant power to move underwater. The batteries fueled its propulsion plant underwater. Without the batteries the U-boat was only a shallow draft surface vessel, unable to close undetected on an enemy target from underwater. Just so, it was unable to hide beneath the sea if discovered. For some unknown reason the message reiterates the exact location of the second attack; DM 2925. It may be only meticulous reporting on the part of the boat. Perhaps the Skipper wished to repeat the location as a reminder to his superiors: he had stayed on station in his area of operations despite the first attack by the blimp. Only repeated attacks were driving him from his post. Also indicative of the seriousness of the matter was the fact that in her message of July 20 the damage to the batteries was reported. This was reported again these nine days later.

In time German research and development would perfect the Schnorchel. This device was a length of tubing extending from the submarine above the surface of the water when the sub was underwater. By 1944 the technicalities of being able to bring in 
enough oxygen, (not including salt water,) distributing the precious oxygen where needed to go throughout the boat, and doing so without the exposed schnorchel giving a signature detectible by allied radar were perfected. ${ }^{152}$ By the end of the war German Uboats so equipped were completing entire trans-Atlantic patrols without ever surfacing. But the U-134 had no such equipment in the critical summer of 1943.

The message of July 29 details the battle damage she had sustained. One of her five torpedo tubes was unworkable. Her ability to shoot was reduced by 20 percent. Worse was the damage to her periscope. Without that she could not hit the target. The U-boat was degraded enough in her operating ability that her commander had removed her far from the sector of the front she had been ordered to. Now he was advising his headquarters of the military need on the part of the boat to retire still further. The U-boat had trouble in getting and staying submerged, in shooting, and even in seeing to shoot.

\section{7.}

12.16

Von B.d.U.

Brosin Rückmarsch antreten ohne Ergänzung. ${ }^{153}$

July 31

1216 Hours

From B.d.U.:

Brosin, retreat. [Expect] no refueling enroute.

This radioed response from German submarine headquarters orders the U-134 out of the battle. The damage inflicted on the submarine by the attack of the K-74 airship, and the more punishing follow-on attack by the Ventura bomber the next night literally put the U-boat out of commission. The gravity of the order to retreat is reflected in the format of its being addressed to Brosin personally.

${ }^{152}$ Doenitz, Memoirs, p. 406.

${ }^{153}$ Kriegstagebuch U-134, final patrol. 
German U-boat command often made a practice of distinguishing the level of importance of an order by the mode of address, the first word of the message. The radio operator who received them decoded routine radio messages to the boat, using the onboard Schlüssel M decoding machine. But important messages began with the word "Offizier," indicating that only an officer was to decode the message. When the U-boat radio operator received any message and at the start of decoding it the first word of the message was "Offizier," he was obliged to stop decoding immediately and bring it to the attention of one of the ship's commissioned officers. The officer, all of whom were trained at this, then took over from the radioman at operating the Schlüssel and decoded the rest of the message. The wardroom being thus first privy to whatever information it contained. When the message began with the name of the ship's captain, he himself decoded it. In this instance, ordering the boat to leave the battlefront and return to port was a matter grave enough to be addressed to Brosin, the Skipper himself.

Admiral Doenitz had a penchant for sending radio messages to his ship captains by name to promote camaraderie and esprit de corps within his command. But the practice also worked to compromise them. When allied intelligence knew what boat was commanded by a particular skipper, the information was an important clue. The Allies kept dossiers on each. Information from allied spies and French Resistance informants sometimes told which boats had put to sea, as well as when. Subsequent intercepted radio messages addressed to the captain, gave away the identity of the enemy combatant. When combined with triangulation or sightings giving approximate location, an insightful and compelling picture of the enemy's circumstances and possible moves could be deduced. 
Another hard aspect of the war at sea is in the advisement to the U-134 to expect no refueling in route. Certainly the potential of the boat had been weighed by the high command. The boat was badly damaged, its offensive capability marginal. Ergo, its usefulness in waging war was gone. As such, they were written off and advised to get home as best they could. Critical, dwindling fuel stocks had to go to those still capable of fighting.

\section{$\underline{6.8}$}

18.50

$\underline{\text { August } 6}$

1850 Hours

\section{Von B.d.U.}

From B.d.U.:

As of August 7 at 8 am switch your radio to

"Ireland" frequency.

The message is self-explanatory. B.d.U. had plotted the likely heading, course and speed of the U-boat and estimated their location. Dead reckoning the boat to be by this time within range of this frequency, they advised the sub to change to this circuit.

$\underline{9.8}$

15.52

August 9

1552 Hours
Von B.d.U.

An U 134, U 107

MNA West sendet auf $9500 \mathrm{~m}$ "VVV" mit eingestreuter

Öse am 10.8 um 08.00, 12.00, 18.00 und 22.00 Uhr je 15

Min. lang, am 11.8 und 02.00 und 06.00 Uhr je 15

Minuten lang. Boote beobachten Sendung und hängen

Ergebnis gelegentlich an FT oder melden sofort nach

Einlaufen an B.d.U. ${ }^{155}$

\section{From B.d.U.}

To U-134 and U-107:

Marine transmitter West will broadcast "VVV" over the $9500 \mathrm{~m}$ band with loop interspersed on

August 10 at 8 am, 12 noon, 6 pm and 10 pm

${ }^{154}$ Kriegstagebuch U-134, final patrol.

155 Ibid. 
for fifteen minutes; and again on August $11^{\text {th }}$ at 2

am and 6 am for 15 minutes. Monitor these

transmissions and report your observations to

Headquarters when you reach port.

The German high command was not insensible to the possibility that Allied intelligence was reading their message traffic. Especially at this time, Gross Admiral Doenitz had concerns about just that possibility. ${ }^{156}$ This signal appears to be a form of circuit testing, possibly for an intelligence appraisal along those lines.

\section{8.}

22.05

\section{Von B.d.U.}

Ab 15.8. 08.00 Uhr "Küste" schalten. ${ }^{157}$

August 14

2205 Hours

From B.d.U.:

Tomorrow at 8 am switch to Coast frequency.

Again, the U-boat headquarters Goliath signals network was keeping track of U134 and the issue of communications.

\section{$\underline{15.8}$}

10.45

Von F.d.U. West

\section{Einlaufhafen für $U 134$ ist Pallice. ${ }^{158}$}

August 15

1045 Hours $\quad$ From Flotilla West Command:

Homeport for U-134 will be La Pallice.

U-134 was going home. This message is from Flotilla West, operating from

France. F.d.U. was the ISIC (immediate superior in command) and Flotilla's assumption of communications points up some of the prosaic organizational details of the prosecution of the battle of the Atlantic. The ordinary but essential logistical matters of sea service, such as where the boat would berth were the concerns of Flotilla, not the high command.

${ }^{156}$ Doenitz, Memoirs, p. 145.

${ }^{157}$ Kriegstagebuch U-134, final patrol.

${ }^{158}$ Ibid. 
The local Flotilla oversaw repairs to the boat. They handled the crew, its pay and all personnel matters. Their duty was to turn the boat around for further operations as quickly, efficiently and thoroughly as possible. By this time the apparatus of maintenance was already at work; work orders were being cut; parts and supply requisitions written up, ordinance reports prepared, mail, liberty and other details being arranged.

For another and more grimly practical reason the local Flotilla West was assuming operational control: U-134 was not out of the war yet. Rather U-134 was heading back into another combat zone. Thanks to the location of its islands, Britain has always been able to exert a major influence on the continent of Europe and especially its Atlantic coastline. In ancient times, the experiences of Caesar, stationed and campaigning many years in Spain, France and Belgium convinced him that nothing short of invasion, conquest and incorporation into the Roman world as another province would resolve the Britons' ability to influence the ancient Atlantic to their own ends by virtue of their location.

During the Battle of the Atlantic the British did just that. From the unsinkable aircraft carrier of their home islands they harried the Atlantic by every means at their disposal; naval blockade, commando ambuscades and air raids. British Coastal Command actively waged war on its doorstep, fighting to prevent the U-boats from entering into the Atlantic, and fighting to deny their safe return home again.

The North Atlantic Ocean from its cardinal points of Greenland-Iceland-UK, to its European continental coastal points of Finland Station, Finestre and Gibraltar was as much the seat of war as had become the Eastern seaboard of America. In retreat, the submarine had not only to disengage from the western front and then cross the vast mid- 
Atlantic, alive with its own dangers. But once approaching home the submarine still had to navigate through the allied cordon working night and day to prevent its safe return. Being a French-based boat, Flotilla West had operational control over the sector of the Atlantic battlefield they were heading for.

\subsection{1}

1121 Hours

\section{Von F.d.U. West} Rückmarsch unter spanischer Küste durchführen. ${ }^{159}$

From Flotilla West:

Make your retreat under the Spanish coast.

This next message from Flotilla is explicit. As the Battle of the Atlantic had become harsher and harsher, the U-boats had taken to traveling as much as possible in neutral Spanish waters as they came and went from their bases along the French coast. This coastal track, known informally as the "Piening Route," after the first U-boat skipper to use it, had some advantages. First of all, the closeness of the Spanish landmass confused allied radar. Also the diplomatic issue of waging war in a neutral state's sovereign sea spaces was contrary to Admiralty Law. The Royal Navy and RAF adhered to diplomacy by prosecuting ASW operations there slightly less aggressively. This was compounded by the reality that Spanish vessels, merchants and fishermen routinely plied the waters. Giving offense to theoretic legal codes was one matter. Allied military operations that accidentally killed or wounded Spanish citizens and destroyed their property had more serious ramifications. British possession of the bastion of Gibraltar, in southern Spain, was always a consideration. Finally, at least a portion of the Spanish population sympathized with the Nazis. Germany had provided the Nationalists considerable military aid, aircraft, armaments, munitions and supplies, including

\footnotetext{
${ }^{159}$ Kriegstagebuch U-134, final patrol.
} 
thousands of volunteer combatants and technicians during the recent vicious Spanish Civil War. Sightings went unreported; clandestine contact within the three-mile limit may have occasionally extended critical information or emergency medical support, and the shipwrecked German submariner who made it alive onto Spanish soil might reasonably expecting to receive aid and comfort.

\section{8.}

09.50

Von F.d.U.:

3 Boote auslaufend auf spanischem Küstenweg. ${ }^{160}$

August 20

From Flotilla West

0950 Hours

Three boats will meet you on the Spanish coastal route.

This message omits important details. When and where this rendezvous was to take place goes unsaid. This is not particularly troublesome in itself. Communications security always strove to keep signals brief and contained. Military procedures incorporate redundancy; backup plans. The exact steps to follow in the event of a particular situation a Skipper received in briefings before his U-boat sortie. Brosin knew where to link up before he ever sailed. He also knew what other scenario aspects to expect. Because the U-134 was disabled, we may conjecture on the identity of the three vessels that were to meet it and the exact arrangements Flotilla was orchestrating to negotiate the coastal passage home.

U-boats often transited Biscay in pairs and larger groups to provide mutual assistance and fire support in the event of air attack. These attacks had become so severe that B.d.U. had recently ordered all boats to transit submerged. This meant a slow crawl along the bottom, surfacing at night to take in oxygen and vent the batteries. This for the

\footnotetext{
${ }^{160}$ Kriegstagebuch U-134, final patrol.
} 
most part obviated the needs and advantages of transiting in groups. Another more desperate measure was slipping damaged boats home across the border in company with neutral civilian vessels.

Spanish fishing trawlers might be induced to take a U-boat into their midst and escort it to the border, camouflaged within their gaggle of nets, trawling devices and small boats. Inattentive Allied patrols drawn to the radar signature might see only a peaceful group of fishing smacks. Where Spanish sympathy and greed were not available to create such operations, phony Spanish fishing vessels made up of French collaborators and even Germans themselves were.

Because the U-134 did not make the rendezvous such details will never be known.

\section{8.}

19.59 CF1284 Von U 134:

Werde von Flugzeug angegriffen. ${ }^{161}$

August 21

1959 Hours

From U-134

Attacked [again] by an aircraft.

By air power projected over the surface of the ocean this U-boat was again attacked. This time it was by one of the ASW combat teams known as "hunter-killers." Late in the day on August 21, 1943 the U-boat reported it was once more under attack from the air. Conversion of the grid coordinates of their report reveals that this engagement took place at Longitude 42 degrees 05 minutes North/Latitude 24 degrees 00 minutes West. A search and collation of the reports of combatants there, then, tells the rest. U-134 ran afoul of Task Group 21.15, southwest of the Azores.

${ }^{161}$ Kriegstagebuch U-134, final patrol. 
The Hunter-Killers were another of the ad hoc composite groups organized to challenge the submarines. Air power was a proven means of doing so. Bringing that airpower to the middle of the ocean was where the hunter-killers came in. The escort carriers were the hulls of half-built merchant ships morphed into baby flattops. Work on their pre-war superstructure design as grain or cargo ships was halted. What amounted to a flat deck of plywood was laid on. In every other way possible the ship was reconfigured to handle aircraft. Fifteen or twenty airplanes went aboard and the escort carrier went to sea. To round out its capabilities and effectiveness three or four destroyers went with it. Command and control of the task group resided with the carrier.

Escort for convoys was a primary mission of the hunter-killers. They provided the vital air umbrella for the merchant ships in mid-Atlantic. Here the land-based aircraft of the allies, because of the range, could not venture. The destroyers of the task group performed as roving pickets along the periphery of the convoy, which were often approaching the size of forty or fifty ships. In the event of contact with the enemy, the task group went to general quarters and shifted to the offensive. The aircraft assigned to the carriers were composite squadrons made up of a mix of Grumman Avenger torpedo bombers paired with Wildcat Fighters. They flew ASW patrols 24 hours a day, 7 days a week. The carriers were equipped to refuel at sea the destroyers that accompanied them. Because of their jury-rigged nature, the escort carriers suffered routine mechanical breakdowns. Their decks were short and none too safe. They were so short and stubby they were nicknamed "Jeep Carriers." They were prone to flight accidents. In the encounter of August 21, the U-134 was attacked by a Grumman Avenger Torpedo Bomber and a Wildcat fighter launched from USS Croatan (CVE-25). 
USS Croatan was a grain ship hull that had been converted to a carrier. The Seattle-Tacoma Shipbuilding Company launched her August 1, 1942. After undergoing much of her conversion work while afloat, she was commissioned April 28, 1943. Departing San Diego July 2, she transited the Panama Canal and reported to Norfolk for duty July 19, where her aviation squadron came aboard. The destroyers USS Paul Jones, USS Belknap and USS Parrot joined her to make up Task Group 21.15. August 5 they deployed to sea just over the horizon from New York City to support Task Force 65 in providing escort for convoys GUS-13 and UGS-14. It was Croatan's first assignment. ${ }^{162}$

To prevent giving away information to enemy agents stateside, precautions were now in effect. Convoy ships did not leave port together. Instead the ships departed at random times on varied courses over several days. Airships and Sub Chasers, Patrol Craft, and Cutters screened their departures. Only after they were out of sight of land did the ships rendezvous and assemble into convoys.

Convoys GUS-13 and UGS-14 were bound for Casablanca with munitions and supplies. ${ }^{163}$ The operation in that theater at the time was the ongoing combat for the island of Sicily and the eventual invasion of the Italian peninsula itself to follow. The heading of the convoy and its escort was almost due west, with the Azores in between. Along the way they met with the U-134.

The resumption of Enigma code breaking in the summer of 1943 led to the midocean battle against the German milch cow supply boats. Cracking Enigma came at the same time that the new escort carriers were putting to sea. These were at once directed to bring their airpower to bear in the mid-ocean hunt for the German refueling submarines.

\footnotetext{
${ }^{162}$ Dictionary of American Naval Fighting Ships, Volume Two, p. 208.

163 Action Report, Commander Task Group 21.15, September 23, 1943.
} 
Destroying the refueling platforms is considered by many to have been the turning point of the Battle of the Atlantic. The attack boats depended on them. Into this battle came the USS Croatan, passing by in time to be vectored onto this activity. U-134 was simply a battle-damaged submarine wending its way through the battlefield to get from point A to point B. August 21 their paths crossed.

That day the Tenth Fleet directed Croatan to an area of believed U-boat concentration at 40 degrees North/21 degrees west to 37 degrees North/30 degrees west. ${ }^{164}$ A large-scale naval combat was going on in the area. Successful attacks targeting the fuel submarines were crippling the U-boat offensive. Only two milch cows remained at sea, but almost sixty attacks boats were scattered across the ocean. One of those milch cows was southwest of the Azores. Several U-boats were in the area biding a time to rendezvous and refuel. USS Croatan task group was diverted to the spot.

In looking at the naval fighting about the Azores Islands, the status of the islands themselves deserves being brought into our understanding. This important island group was a colony of Portugal, a neutral state during World War II. Portugal was a neutral state with a heritage of aligning itself with Britain against aggression by Continental powers. Yet the friendliness between Portugal and Britain did not allay the gravity with which the Allies regarded the islands. Friends or not, Britain held forces ready to seize the islands if they moved to support the Axis. Likewise the Madeira and Cape Verde Islands, and the Spanish Canaries were all targeted for takeover. Contingency plans for the seizure of these islands exist to this day.

${ }^{164}$ USS Croatan (CVE 25), War Diary, August 7, 1943. 
The strategic importance of the island groups to the Battle of the Atlantic should also reference the south Atlantic islands of Ascension, Saint Helena and Trinidad Martin Vas. These three British islands were unsinkable life rafts in the midst of the Atlantic. They were an invaluable support to the Allies, providing fuel to patrolling destroyers, landing strips for aircraft, safe haven and communications. They were a string of beacons beneath the Allied air bridge from Brazil to Africa.

Off the Azores Croatan turned into the wind. At 0639 she began launching the first five planes of the day on ASW patrol. Her war diary of that day reveals how busy her flight deck was. The five initial TBF's (Torpedo-Bomber Fighters) took eleven minutes to launch on a double triangular offensive search pattern. All were recovered by 1050. At 1043 a sixth was launched. At 1325 she started launching another six TBF's and F4F's with a second double triangular search flight plan. One developed engine problems and returned and landed within fifteen minutes. ${ }^{165}$

At 1517 more planes took off. By 1605 the five sent up 1325 were recovered. 1713 another eight planes were catapulted on a third double triangular search pattern. Between 1834 and 1916 four more planes were launched. From 1958 to 2024 another nine planes were recovered. Twenty-six aircraft launched and recovered in thirteen hours. ${ }^{166}$ This equates to an average of an airplane taking off or landing every fifteen minutes.

One plane on the morning patrol reported disappearing radar blips. At 1800, eighty miles out from USS Croatan, a pair of planes from the evening patrol, Grumman

\footnotetext{
${ }^{165}$ War Diary, USS Croatan (CVE 25), Supplimentary Remarks by the Air Officer, Aug. 21, 1943.

166 War Diary, USS Croatan (CVE 25), Supplimentary Remarks by the Commanding Officer, Aug 21, 1943.
} 
TBF Avenger T-9 and Wildcat FM-3, cruising at 1000 feet sighted the U-boat. The U134 was surfaced and it apparently saw the approaching aircraft first. The U-boat commenced firing. The twinkling flash of her guns attracted the notice of the flyers.

We may conjecture concerning this. Admiral Doenitz had rescinded the B.d.U. "fight back" order, requiring surfaced boats to stand to and fight it out on the surface rather than submerge. That order was not an excess of machismo; U-boats submerging in the face of the enemy were helplessly exposed for the thirty seconds it normally took for their dive to reach a safe depth. But in firing first and so revealing themselves and offering combat, it may be the boat's damages precluded a hasty dive.

Pilot of the Wildcat was Lieutenant (Junior Grade) Ygnacio Toulon III. The Avenger was flown by Lieutenant (Junior Grade) Morris L. Nelson. The turret gunner behind him was Petty Officer First Class H. L. Helwig. The Fighter was armed with four wing machine guns. The Avenger carried four Mark 47 Torpex depth bombs. Nelson radioed in the contact.

The Wildcat attacked first, making strafing runs to suppress the return fire of the U-boat. During each the boat made portside turns to evade. After three passes the fighter had expended his 1,000 rounds of ammunition. The Avenger made his bombing run. The four bombs dropped were near misses, reported by the turret gunner falling in a line along the port side, followed by four explosions underwater. Although the splashes were observed to envelop the U-boat it appeared undamaged and continued to fire.

Wildcat FM-3 was low on fuel and broke off to return to Croatan. T-9 pulled out of range, continued to circle the target and radioed again for a second strike. The submarine was observed to cruise in a slow circle for 55 minutes. The U-boat apparently 
sent a radio message. The boat then submerged and contact was lost. The boat's actions following the attack may again infer operating difficulty. We can definitely see striking proofs from the American side of the immutable fact that projecting force always entails considerable difficulty and loss.

First, there was miscommunication. The initial contact report was not received as T-9 was off frequency. When the U-boat's wireless transmission was intercepted and triangulated, Croatan went to General Quarters and did launch a second strike. But they launched on the reciprocal bearing in the exact opposite direction. Flight deck operations on the escort carrier went badly. Returning from the skirmish to USS Croatan, FM-3 crashed on landing, sweeping away the barrier and damaging propeller and landing gear. So did a second FM returning from patrol to refuel. By the time the deck was cleared and a second strike launched in the right direction the target was gone. USS Paul Jones was sent ahead to attempt to hold-down and regain contact. It may be observed that the problem of ASW refueling challenges was for the Allies also a problem. The destroyers in USS Croatan's war party required refueling by the carrier every few days of steaming. Choppy seas the day before had precluded refueling operations. Now her destroyers were dipping to half-empty fuel bunkers. In 36 hours the hunters would be forced to lie to and refuel.

That night as Croatan closed to within forty miles to get into position for a dawn search a main-feed pump breakdown reduced her speed to ten knots. With a radar malfunction, bright moonlight and only two destroyers on picket, the carrier herself was exposed to submarine counterattack. Fortunately for USS Croatan no submarine attacked. 
Next daybreak the absence of wind necessitated use of catapult launches. The first aircraft to launch slipped its bridle, disengaged from the track, skidded overboard and crashed into the sea. USS Belknap rescued the pilot. The catapult was disabled and the lack of wind prevented any further launches until 1735 that day. One aircraft then reported sighting an oil slick two miles in length at 41 degrees 10 minutes North/23 degrees 45 minutes West. This may or may not have had any connection.

No further communications are recorded.

\section{B.d.U. CLOSING ASSESSMENT:}

U 134 meldet sich nicht vor Einlaufhafen an. Auf Befehl zur Standortmeldung am 6.9. antwortet es nicht. "U 134" wurde möglicherweise bei dem gemeldeten Angriff am 21.8. vernichtet. "U 134" wurde mit Wirkung vom 6. September 1943 am 15.9. für vermisst ein Stern, am 3.6.44 für vermisst zwei Stern erklärt. ${ }^{167}$

U-134 does not signal its return to home base. U-134 does not respond to order to report position on September 6. U-134 probably destroyed during the attack reported August 21. As a result of September 6, 1943, effective September 15 she is listed missing in action with "One Star." As of June 3, 1944 missing in action with "Two Stars."

The assessment of headquarters, though understandable, was wrong in its particulars. U-134 was still very much alive on August 21, 1943. She survived the air attacks of that day and escaped from the USS Croatan Task Group. The aviators of TB-9

\footnotetext{
${ }^{167}$ Kriegstagebuch U-134, final patrol.
} 
reported seeing her submerge. Her previous course was towards Spain, and into Spanish waters she sailed three days later.

She was cruising into the bomb sights of British Coastal Command.

Royal Air Force Squadron 179 was formed in England on September 1, 1942 from a detachment of squadron 172. The squadron flew Wellington Bombers. They were deployed to Gibraltar to cover the approaches to the Mediterranean. Their patrols swept the Atlantic to the Madeira Islands in the south off Morocco, and the Iberian west to El Ferrol. August 24, 1943 the northerly night patrol was by two Wellingtons, flight J/179 "J for Jane," and flight C/179 “C for Charlie."

Understanding how the British Empire came to be projecting power and prosecuting war from this airstrip in Spain is worth a digression. It underscores the intricate diplomatic considerations of the Battle of the Atlantic. It is a commonplace, and not an altogether accurate one, that Spain and the Franco regime supported the Nazis. They did, and they didn't. After overrunning France in 1940, Hitler wanted to remove from the board the British castle at Gibraltar. Due to the hesitation of the Franco regime, Hitler was denied this move. As an opening negotiation German Foreign Minister Ribbentrop approached Spanish Interior Minister Ramon Serrano Suñer to permit a German expeditionary force to access the Pyrenees, cross Spain and attack Gibraltar. German siege artillery, paratroops and glider assault troops and support forces were identified and tasked with the operation, codenamed Operation Felix. But despite fulsome phrases expressing support for the Axis, the answer from the Spaniards was surprisingly equivocal: Franco would consider it. 
Spain at the time was prostrate. Three years of ferocious civil war had claimed over a half-million combat deaths, out of a population of 37 millions. Her towns, industry and agriculture were wrecked. Shipments of American wheat were preventing starvation. The countryside was under martial law. To those who have not experienced such considerations, it would seem the most logical thing for Franco to throw his lot in with the Axis. But precisely because of the situation in Spain, he demurred.

The Caudillo's rise from rebel to Generalissimo had shown him the very uncertainty of war. If the British Empire appeared down, it was still not out. Why should Spain openly ally itself with the Axis, which allowing Gibraltar to be stormed and captured would have done, when the greater issue of who would ultimately win the contest was still in doubt? British rent for Gibraltar in the form of gold bullion propped up the Franco regime. Throwing that away was not easy. Fresh hostilities and subjecting the hungry Spanish people to the further suffering of World War II risked everything already won at terrible price. If the Axis did not win, Franco would lose. He was already the victor, why risk it? ${ }^{168}$

Besides, Spain was helping the Axis, providing aid and comfort to her U-boats, clandestine refueling and safe haven. Most importantly, the German negotiator Admiral Wilhelm Canaris confided to the Spaniards that the Reich was too encumbered with other military concerns to force Spain to give an immediate yes or no decision. ${ }^{169}$ Canaris was secretly anti-Nazi and later found guilty of plotting against Hitler's life and executed. After the war Spain gave his widow a pension. The information he shared with Franco

\footnotetext{
168 There was an additional issue over Morrocco. The region was then divided between Spain and France. The German puppet government in Vichy was pressing French claims to the region, at the expense of Spanish sovereignty.

${ }^{169}$ Franco, Silent Ally in World War II, p.15.
} 
was critical. Instead of permission for Operation Felix, Franco requested food for the Spanish people.

So important was the matter of Gibraltar that Hitler himself came to meet with Franco in the passes of the Pyrenees at Hendaye. But this meeting October 23 was filibustered by the Spaniard's sad-faced and apologetic demands and inconclusive caviling. Hitler was distracted by his secret upcoming invasion plans for Russia.

Franco made a diverting offer to raise for the Axis a division of Spanish volunteers. Besides the military value of 20,000 soldiers, there was the propaganda value of it. For Franco, it would remove from Spain that many hungry mouths. That these volunteers were the most energetic and warlike (and potentially troublesome) men in Spain may also have occurred to the Caudillo. Hitler was enchanted with the proposal. Felix was postponed.

When the Nazis invaded Russia that summer the call went out for volunteers in Spain. Nicknamed the "Blue" division for their penchant for wearing blue shirts emblematic of the Falange, these Spanish volunteers were incorporated into the German order of battle as the $262^{\text {nd }}$ Infantry Division. Sent to the Eastern Front, they entered the line and served in combat for the next few years. Throughout that time the German High Command continued to urge seizing Gibraltar. Hitler intrigued to cultivate a more cooperative replacement to Franco from among the general officers of the Blue Division. ${ }^{170}$ But the unsuccessful fighting on the Eastern Front never allowed him to devote time to bringing Spain into subordination.

\footnotetext{
${ }^{170}$ Hitler's Spanish Legion; the Blue Division in Russia, p. 165.
} 
So it was that the Royal Air Force continued to operate from the rock of Gibraltar. At 1900 on August 24, 1943 Gibraltar launched the first Wellington bomber, Flight J for Jane. Companion flight $\mathrm{C}$ for Charlie would take off two hours later. Both were fitted with Leigh Lights. This was yet another invention of war; a million-candlepower retractable swivel searchlight mounted under the fuselage of the bomber. ${ }^{171}$

Canadian Flying Officer Donald Farquhar McRae, serial number J9405, piloted flight J for Jane. He was thirty years of age, born in Stavely, Alberta on March 10, 1913. He attended grammar school and high school at Agassis. He also attended the University of British Columbia in Vancouver. Before the war he worked as a Caterpillar Operator for the General Construction Company in Medicine Hat, Alberta. He joined the RAF May 1, 1941. ${ }^{172}$

After being accepted for flight training he followed the usual pipeline of military coursework at bases in Canada, graduating from initial training that July, primary flight school in September and advanced flight training that December. His Pilot's Flying Badge was awarded twelve days after Pearl Harbor. McRae earned the Distinguished Flying Cross, in part for his work this night.

The rest of the crew of $\mathbf{J}$ for Jane were from around the Commonwealth. The wireless operator/air gunner Flight Officer R. K. Senior was from the Royal Australian Air Force. Flight Officer R.W. Hegan and Flight Sergeants G.V. Cormack and J. Stead were British. Flight Sergeant D.E. McKenzie was from the Royal New Zealand Air Force. Their flight up the west coast of Iberia was uneventful the first five hours. Approaching their turn-back point, at 0010 a radar contact was made off Cape Silleiro.

${ }^{171} 179^{\text {th }}$ Squadron RAF War Diary, August 24, 1943

${ }^{172}$ London Gazette RAF Decoration Digest for Press Release number J9405 
The location was southeast their position at five miles out, 42 degrees 07 minutes North/09 degrees 30 minutes West.

The U-134 was seeking its rendezvous. Reaching the Spanish coast from the Azores was a matter of seamanship, charting the sun and shooting the stars at night. A signal beacon broadcast from the radio station in the nearby Spanish port of Vigo might have helped the boat make landfall.

During the Spanish Civil War, German assistance to the nationalist side included the gift of a state-of-the-art radio station and its servicing technicians erected at Vigo. Germany continued to subsidize the station and its staff of German nationals, including no doubt B-Dienst operatives. Vigo hosted a variety of Kriegsmarine support. But if the U-134 was homing in on Vigo, it was out of luck. Wellington bomber flight $\mathrm{J}$ for Jane was homing in on it.

At a mile out the pilot dropped to 300 feet and engaged his Leigh Light. The Leigh Light was calibrated to the plane's radar. Its beacon of light could focus on whatever the source was that the radar was tracking. The light was for nighttime visual during the last mile run up on a suspected enemy; for positive identification and targeting. Closing at 110 knots, the beam of light shot ahead of the aircraft and fastened on the radar contact, the submarine below. The U-boat was riding at all stop. J for Jane recognized her for the enemy, and just as quickly switched off the light.

The pilot banked, came into position for a starboard quarter straddle of the conning tower, dropped to 150 feet and closed on the target. The Leigh Light was reengaged at half a mile, instantly fastening on the target. The U-boat anti-aircraft guns opened fire. The nose gunner of the Wellington returned fire. Directly over the target the 
Wellington released its payload of six depth bombs. The Leigh Light was switched off. The airplane tail gunner reported witnessing the submarine tracer rounds for three seconds longer, and then the shooting ceased abruptly. The radar signature disappeared, indicating the U-boat had gone underwater.

Wellington flight $\mathrm{J}$ for Jane circled in the vicinity for the next ten minutes. Unable to remain longer, she reported her contact and turned for Gibraltar. Wellington ASW patrol flight C For Charlie intercepted the report and turned to the position. Arriving at 0211 , she searched the position for an hour. Nothing was seen. No contact of any kind was reported.

\section{B.d.U. FINAL ENTRY:}

\section{Es ist Totalverlust anzunehmen.}

Für den Befahlshaber der Unterseeboote

- Der Chef der Operationsabteilung ${ }_{-}^{173}$

Total loss is to be assumed.

For the Commander, U-boats

Chief of Operations

//initials//

The entry above concludes the kriegstagebuch of U-134.

All other U-boats which could have been there that night are accounted for. Radar contact was lost after the bombing. The U-134 went underwater. She has yet to rise again. Unless, like the legendary Lost Dutchman, some agency of the supernatural

${ }^{173}$ Kriegstagebuch U-134, final patrol. 
sustains her beyond time and the materiel world, the assessment of the U-boat Command is correct. The attack of August 24, 1943 ended her patrol.

\section{$\underline{\text { In Conclusion }}$}

The study of the combat patrol of this U-boat cannot fail to recognize the great lengths this combatant went to in order to wage war, and the dogged persistence with which they strove to carry on. And this particular boat was unexceptional and most unfortunate. The kriegsmarine was a remarkable enemy, and their efforts deserve the closest examination.

We may lay up the victory in the Battle of the Atlantic to a pair of primary reasons, and a number of tertiary ones. We can list, in no particular order, the secondary causes of battle victory:

1) Destroying the Nazi's fuel capability.

2) Total mobilization of entire populations to the war effort magnified resistance to the Nazi attacks.

3) The stupendous American shipbuilding program negated the all-important losses of ships.

4) The escort-carriers built from scratch extended air power into the middle of the Atlantic battlefield.

5) Technological advances and reading the Enigma codes compromised the Nazi war aims.

6) The retention of Gibraltar by the Allies.

Yet with all these it took five years of the bitterest struggle for the Allies to prevail. 
A reading of the reports of both sides reveals a very simple human factor present in each engagement and of split-second decisiveness to every outcome: the human faculty of eyesight. That is the visual contact of the human beings involved, be they kriegsmarine deck gunner, nervous blimp bombardier, or tractor-driver turned pilot; sighting the enemy and responding was the outcome determinant.

From this we may reason that the participants themselves are the key of the battle. This leads to the intangible of military leadership. Here is a cause for defeat. No fault can be assigned to the U-134. Those officers and men, ill-starred boat though it was, gave nonetheless a singular display of maritime skill and combat toughness. It took half the Navy to put them down. Nor were they anything but usual. It was in their leaders, and in The Leader himself wherein lay the fault.

Adolf Hitler failed to fight the Battle of the Atlantic as competently as the Allied leaders. Hitler was a harrowingly phenomenal murderer. Fortunately for the world, he was a less efficient commander. Consistently he missed the schwerpunkt, the main chance of battle. Under his direction the military and the entire Nazi war apparatus went to the wrong place at the wrong time, doing the wrong things for the wrong results, just often enough to tip the scales. The secondary cause of the victory was Adolf Hitler's faulty leadership.

Even then, he was so well seconded by the Nazi fighting forces that he would have won, except for what ultimately blocked the way: the Allied fighting men. It is to them the credit for victory goes. It goes especially to the over 40,000 who, in the battle of the Atlantic alone, gave their lives in the fight. It was their blood sacrifice and the willingness to pay it again and again, as often as it took, that brought victory. 
This study observes only one example of Allied combat death. But the whole action of the K-74 embodies the sacrifice. Its crew made a hopeless sacrifice attack, knowing they would go down. What bigger, easier target is there than a blimp at pointblank range? Where less inviting to enter than into mid-ocean at midnight? Still they went in to the crucible of combat. That Providence spared the lives of all but one underscores the mercy at work, and the mystery of how the Nazis were defeated.

The victory was through the life of the heroic bombardier, and all of the rest who gave their lives. Goliath was beaten by a pebble.

\section{8 mystery photos in PROCEEDINGS Magazine}

The January 1958 issue of the United States Naval Institute journal Proceedings published an article submitted by Mr. Franz Selinger of Germany on page 96 entitled "German Submarine Sinks U.S. Blimp." 174 Along with it were two photographs. One photo showed a blimp-like object crashed at sea, and was captioned "Shot Down By A UBoat." The other showed U-boat crewmen hauling blimp-like fabric out of the water onto the deck of their submarine. This photo was captioned "U-134 Salvages the K-74."

The article stated that U-134 lingered after the battle with K-74 and took these photos of the airship, and that on its return voyage the U-134 rendezvoused with another U-boat transferred the pictures before they were sunk. The photos purportedly made their way back to Europe in this way. They had some circulation within the kriegsmarine during the remainder of the war.

\footnotetext{
${ }^{174}$ Selinger, Proceedings, January, 158, p. 96.
} 
These photos were inconsistent with the known facts and the testimony of the K-74. In the course of researching the historic event some thirty years later Mr. Selinger was located in Germany by this author. He was kind enough to answer inquiries as follows:

“... Concerning the publication of an article in the US NAVAL INSTITUTE PROCEEDINGS of 1958 which I wrote by myself, on the encounter of the German Uboat "U-134" with the USN-blimp "K-74." That article was based on two photographs of the salvage of an airship hull by a Type VII C U-boat, the caption of these photographs explaining the destruction of an American blimp by a German U-boat in the Caribbean in summer 1943. Only one US Airship was shot down by a U-boat, and that was "K-74" destroyed by "U-134." So I was sure that the photographs were taken from "U-134" and delivered to Germany by another U-boat that had met "U-134" before being sunk in the Bay of Biscay in August 1943.

"At the time of publication 1958 I did not know that "U-134" had not met any other Uboat on its return passage, as the log books were at the time still kept by the British Admiralty and I could not check the U-boat operations in July and August 1943 by researching official documents. Even the captions of the "official" PK \{Propaganda Kommando photographs refer to the destruction of "K-74". Now it must be stated that these photographs were taken from another U-boat, salvaging a barrage balloon hull, but were used as propaganda photos for illustrating the success of "U-134", even \{though\} that boat did not more exist in October 1943, the date of the publication.

"Years after the publication of the article I could check the documents on U-boat operations of the Bundesarchiv-Miltärarchiv at Freiburg, Germany, and then I discovered my error. In coincidence with that finding I received a letter of the pilot of a PBM- 
Mariner flying boat, who had attacked "U-134" on July 10, 1943, and narrowly escaped the destruction of his plane, reaching his base on Bermuda with a heavily damaged aircraft. He brought back a photograph of the attacked U-boat that revealed the lack of a deck gun, contrary to the photograph of the balloon salvage published, that shows a deck gun. So it was confirmed that the photographs erroneously published as taken from "U134 " were actually fakes, and taken at another occasion.

"Even that finding happened many years after the article mentioned and due to the fact I am no more a member of US Naval Institute as retired since nineteen years, I had no chance to correct my error of now forty years ago, and I have to excuse myself for. Corresponding with Lt. Comdr. J. Gordon Vaeth, USN, twenty years ago, he told me after researching the radio traffic records kept by National Archives, that Kptlt. Brosin, the captain of "U-134" did not mention the investigation of the wreck of "K-74" when reporting home his success by radio, and he would have done it, if he actually salvaged or investigated the wreck. That is another argument for disproving the contemporary captions of the photographs published. I am sorry that I cannot give a positive explanation, but we have to confess errors if we discover them.

Yours sincerely, Franz Selinger, Ulm an Donau, Germany” 175

\footnotetext{
${ }^{175}$ Selinger to Atwood, September 3, 1998, author's files.
} 


\section{Postscript}

After World War II, the British Admiralty allowed ONI to microfilm the U-boat archives they had captured, and certain interested Allied officers were permitted to study the records at Kew Gardens, London. Wartime Naval Airship Commander Rear Admiral Charles E. Rosendahl sent his former aide Gordon Vaeth to research them for airship contacts. Vaeth uncovered the U-134 transmissions and reported the find. Adm. Rosendahl, and several crewmen of the K-74 who learned of this, spent years petitioning the Board for the Correction of Naval Records to review the incident. Finally, in 1960, coincidental with the declassification and public release of the U-boat archives, the Secretary of the Navy approved the award of The Distinguished Flying Cross to Nelson G. Grills. The surviving crewmembers of the K-74 were awarded the Navy Commendation Medal.

No award was made in the case of the bombardier, Isadore Stessel, as his immediate family was all deceased. Following Stessel's death in combat, his mother entered a sanitarium and never emerged. His sister died of tuberculosis and his father of a broken heart.

In 1998, this thesis writer published an article on the K-74. Saul Stessel, the cousin of the K-74 bombardier, happened to live in south Florida and read the article. Soon after, he made contact. As a result, the Navy issued the Navy Commendation Medal of Petty Officer Isadore Stessel posthumously and it was presented by the Naval Order of the United States to this next-of-kin in a memorial ceremony on the grounds of the former Navy Blimp Station here. The encounter was the beginning of this thesis. 


\section{BIBLIOGRAPHY AND PRIMARY SOURCES}

Althoff, William F. Sky Ships, New York, Orion, 1990.

Atwood, Anthony D. "Blimpie and the Sub," Miami Herald, Tropic Magazine, March 9, 1997.

. "Battle Between the Blimp and the Sub," Naval Aviation News, Vol. 79, March-April 1997.

Beaulac, Willard L. Franco: Silent Ally in World War II, Illinois, Southern Illinois University Press, 1986.

Botting, Douglas. The U-boats, Alexandria, Virginia, Time-Life Books, 1979.

Browning, Robert M. Jr. "Captains of the Port," Office of the Coast Guard Historian, Washington, DC, 1993.

Blair, Clay. Hitler's U-boat War; The Hunted, Vol. Two, New York, Random House, 2000 .

Collins, Richard. “Last Patrol of U-134,” Aviation History, September 1994.

Doenitz, Karl. Memoirs; Ten Years and Twenty Days, Cleveland, World Publishing Co., 1995.

Franks, Norman. Search, Find and Kill, London, Grub Street, 1995.

Gannon, Michael, Operation Drumbeat, New York, Harper and Row, 1990.

Howarth, David. The Dreadnoughts, Chicago, Time-Life Books, 1980.

Hoyt, Edwin P. U-boats Offshore; When Hitler Struck America, New York, Stein and Day, 1978.

Jackson, Robert. Airships in War and Peace, London, Cassell, 1971.

Kelshall, Gaylord T.M. The U-boat War in the Caribbean, Annapolis, Naval Institute Press, 1994.

Kemp, Paul. U-boats destroyed; German Submarine Losses in The World Wars, Annapolis, Naval Institute Press, 1977.

Kimball, Warren F., ed. Churchill and Roosevelt, the Complete Correspondence, New Jersey, Princeton University Press, 1984. 
Kimball, Warren F. Forged in War; Roosevelt, Churchill and the Second World War, New York, William Morrow Co.,1997.

Kleinfeld, Gerald R. and Tambs, Lewis A. Hitler's Spanish Legion, the Blue Division in Russia, Southern Illinois University Press, 1979.

Liberman, Si. "Death of a Sub-Killer," Family Weekly, New Jersey, November 26, 1961.

Loewenhiem, Francis L., Langley, Harold D., Jones, Manfred, ed. Roosevelt and Churchill; Their Secret Wartime Correspondence, New York, E.P. Dutton, 1975.

Leutze, James R. Bargaining for Supremacy; Anglo-American Naval Collaboration 1937-1941, Chapel Hill,University of North Carolina Press, 1977.

Meigs, Montgomery C. Slide Rules and Submarines; American Scientists and Subsurface Warfare in World War II, Nation Defense University Press, Washington, DC, 1990.

Morison, Samuel Eliot. History of United States Naval Operations in World War II, Vol. Two, Boston, Little, Brown \& Co., 1954.

Noble, Dennis L. "The U.S. Coast Guard in World War II; The Beach Patrol and Corsair Fleet," Office of the Coast Guard Historian, Washington, DC, 1992.

Payne, Lee. Lighter Than Air, New York, Orion, 1991.

Perry, Hamilton Darby. The Panay Incident; Prelude to Pearl Harbor, Toronto, MacMillan, 1969.

Piekalkiewicz, Janusz. Sea War, 1939-1945, Harrisburg, PA, Historical Times, Inc, 1987.

Reynolds, David. The Creation of the Anglo-American Alliance 1937-1941, Chapel Hill, University of North Carolina Press, 1982.

Rogge, Bernhard and Frank,Wolfgang. The German RaiderAtlantis, New York, Bantam, 1956.

Sainsbury, Keith. Churchill and Roosevelt at War; The Warthey Fought and the Peace They Hoped to Make, New York, New York University Press, 1994.

Salmaggi, Cesare and Pallavisini, Alfredo. 2194 Days of War, New York, Gallery Books, 1979. 
Selinger, Franz. “German Sub Sinks U.S. Blimp,” Proceedings, Annapolis, Naval Institute Press, January 1958.

Shock, James R. U.S. Navy Pressure Airships, Vol. Two, Florida, Atlantis Press

Vaeth, Gordon J. Blimps and U-boats, Annapolis, MD, Naval Institute Press, 1992.

Werner, Herbert A. Iron Coffins, New York, De Capo Press, 1969.

White, John F. U-boat Tankers 1941-1945, UK, Airlife Publishing, 1998.

White, William Joseph. Airships of the Future, New York, Sterling Publishing, 1978.

Wynn, Kenneth. U-boat Operations of the Second World War, Volume One: Career Histories, U1-U510, Annapolis, MD, Naval Institute Press, 1997.

\section{PRIMARY SOURCES:}

Kriegstagebucher (War Diaries), U-134

Einsatzdaten, U-134

Weitere Angaben zum Boot, U-134

Der Frachtbrief den Matrosen, U-134

Kriegstagebuch, U-488.

Kriegstagebucher, U-134.

Radio transmissions of the U-134, June 9 to August 24, 1943, National Archives and Records Administration, microfilm T1022, roll 3072

Military Dictionary, War Department, English-German/German-English, Govt Printing Office, Washington, August 1941.

Naval Station Bermuda War Diary, July 8, 1943

Photograph of U-134 under attack taken by Martin Mariner P-3 of VP-201, July 8, 1943.

Photographs of battle damage to Martin Mariner P-3, VP-201, Naval Air Station Bermuda, July 8, 1943

U.S. Navy Gulf Sea Frontier, War Diary, July 17-20, 1943

Action Report, U.S. Navy airship squadron ZP21, July 21, 1943; preliminary report 
Action Report, U.S. Navy Airship Squadron ZP21, July 25, 1943; final report

First Endorsement, Commander Fleet Airship Wing TWO, July 27, 1943

Second Endorsement, Commander, Gulf Sea Frontier, August 3, 1943

Third Endorsement, Commander, Fleet Airships Atlantic, August 10, 1943

Fourth Endorsement, Commander Air Force, Atlantic Fleet, August 31, 1943

Fifth Endorsement, Commander, Atlantic Fleet, September 11, 1943

USS Dahlgren (DD 187), Deck Log, July 18-20, 1943

Action Report, Commander Bombing Squadron 132, July 21, 1943

First Endorsement, Commander Fleet Air Wing TWELVE, August 1, 1943

COMINCH analysis of VP-132 Action Report, August 12, 1943

USS Croatan (CVE 25), War Diary, August 21, 1943

USS Croatan (CVE 25), War Diary, Supplementary Remarks of the Air Officer, August 21, 1943

USS Croatan (CVE 25), War Diary, Supplementary Remarks of the Commanding Officer, August 21, 1943

Action Report, Commander Task Group 21.15, September 3, 1943

Royal Air Force, Squadron 179, War Diary, August 24, 1943

Royal Air Force Decoration Digest for Press Release \#j9405, London, September 27, 1943.

Al Cope, CAPT, USN(Ret), interviews

Nelson Grills, LT, USNR, K-74 pilot, interviews

Bob Bourne, ARM2, USNR, K-74 lead radioman, interviews

John F. Rice, ARM3, USNR, K-74 radioman, interviews

Johnathan L. Schmidt, AMM3, K-74 machinist mate, interviews

Max E. May, AM3, USNR, K-32 lookout, interviews

“The Daily Mirror newspaper,” Vol. 20, No. 33, New York, NY, July 31, 1943.

Philip Lundeberg to Alfred Cope, September 18, 1952, author's files. 
Nelson Grills to Alfred Cope, October 2, 1952, author's files.

Alfred Cope to Philip K. Lundeberg, October 17, 1952, author's files.

Philip K. Lundeberg to Alfred Cope, October 27, 1952, author's files.

Letter of Chief of Naval Personnel, Pers-G251-ehw, serial 55183 77, to Robert H.

Bourne, December 7, 1960

Secretary of the Navy Letter of Commendation, December 7, 1960.

Herr Franz Selinger to Anthony Atwood, September 3, 1998, author's files. 


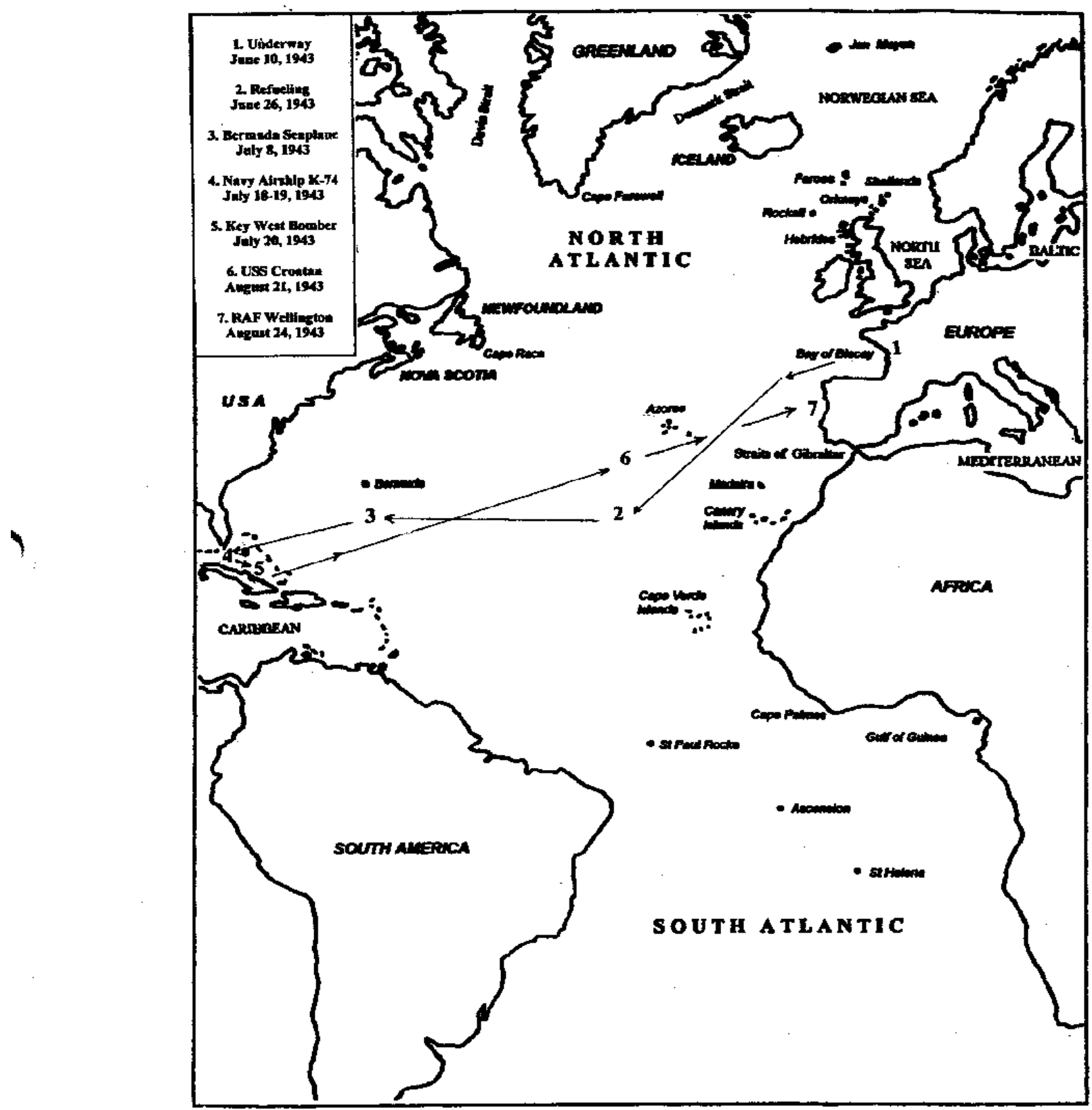

THE FINAL PATROL OF U-134 


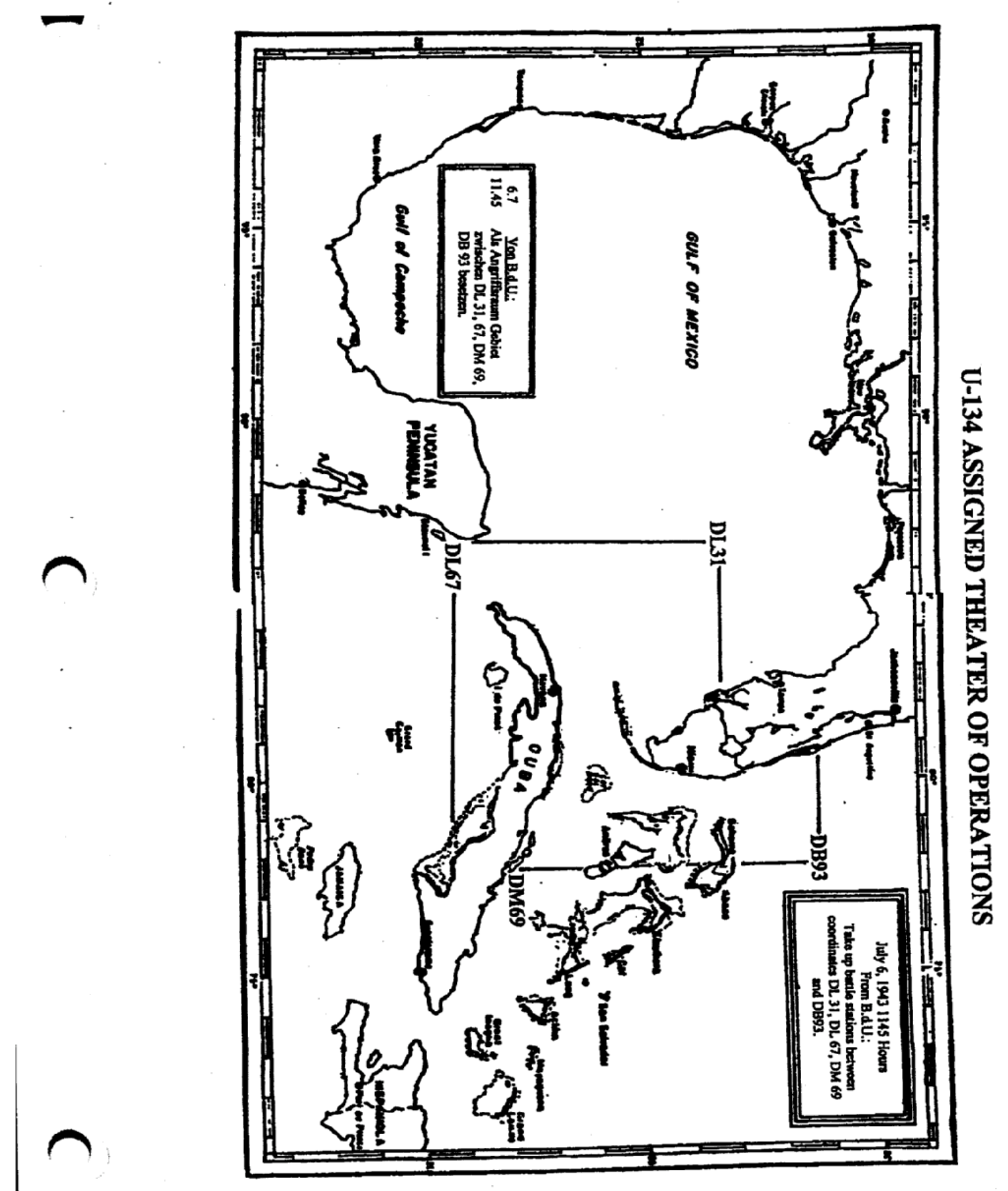




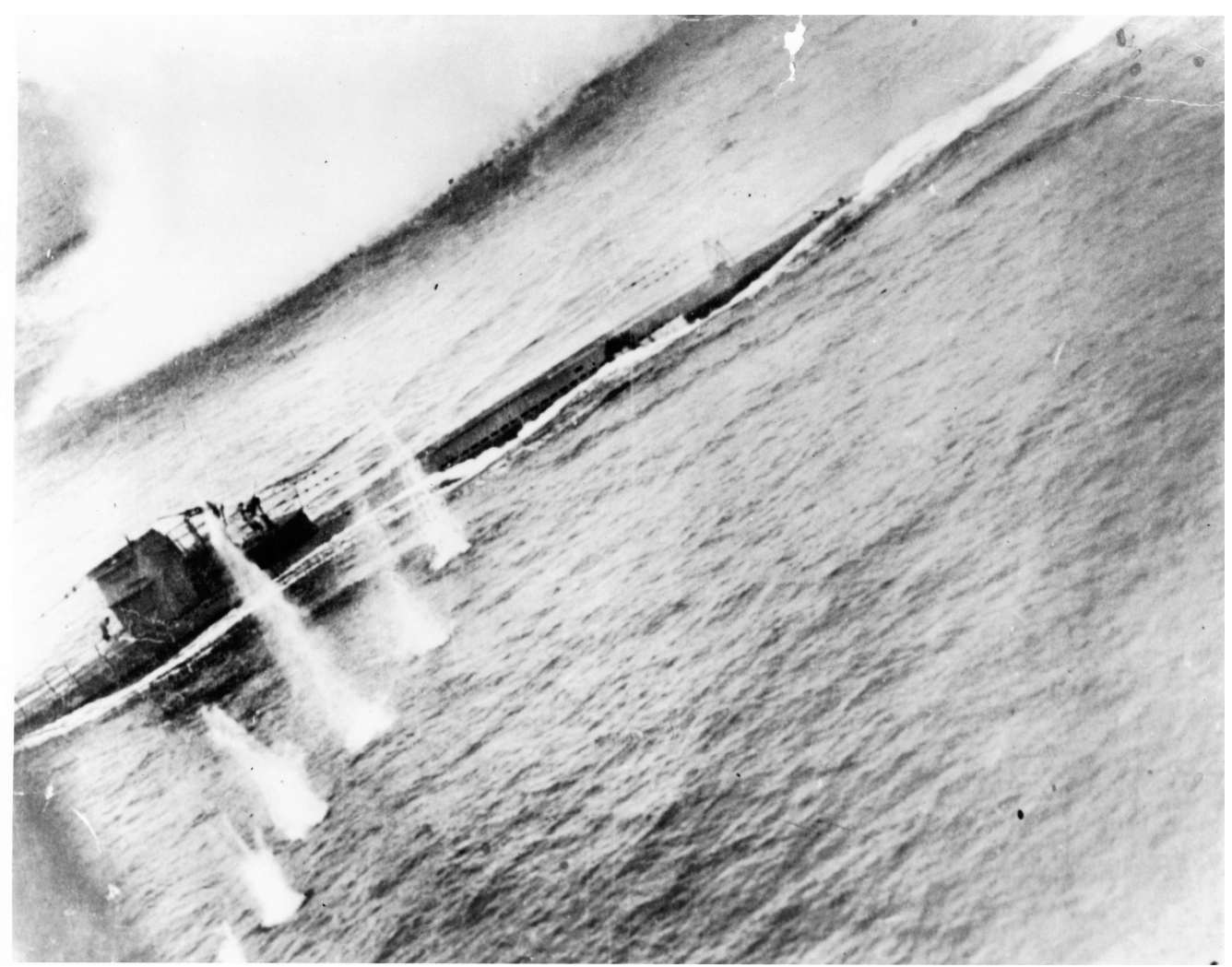

Combat between U-134 and VP-201 PBM-38 S.E. of Bermuda 8July 1943. Photo by PBM Navigator, ENS Wade. Near miss by bombs. Note: there is no deck cannon

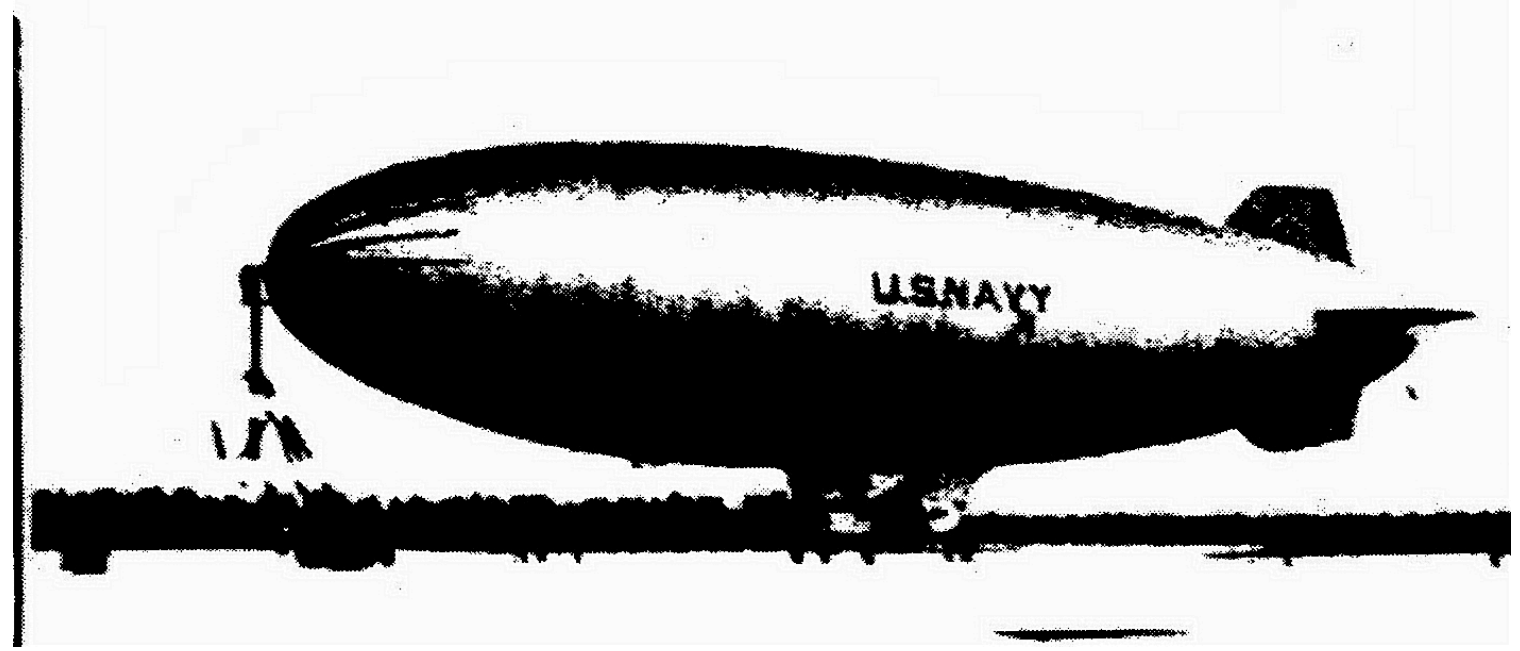

Typical WWII Navy K-Ship: ten-man crew, four depth bombs, one 50 CAL 


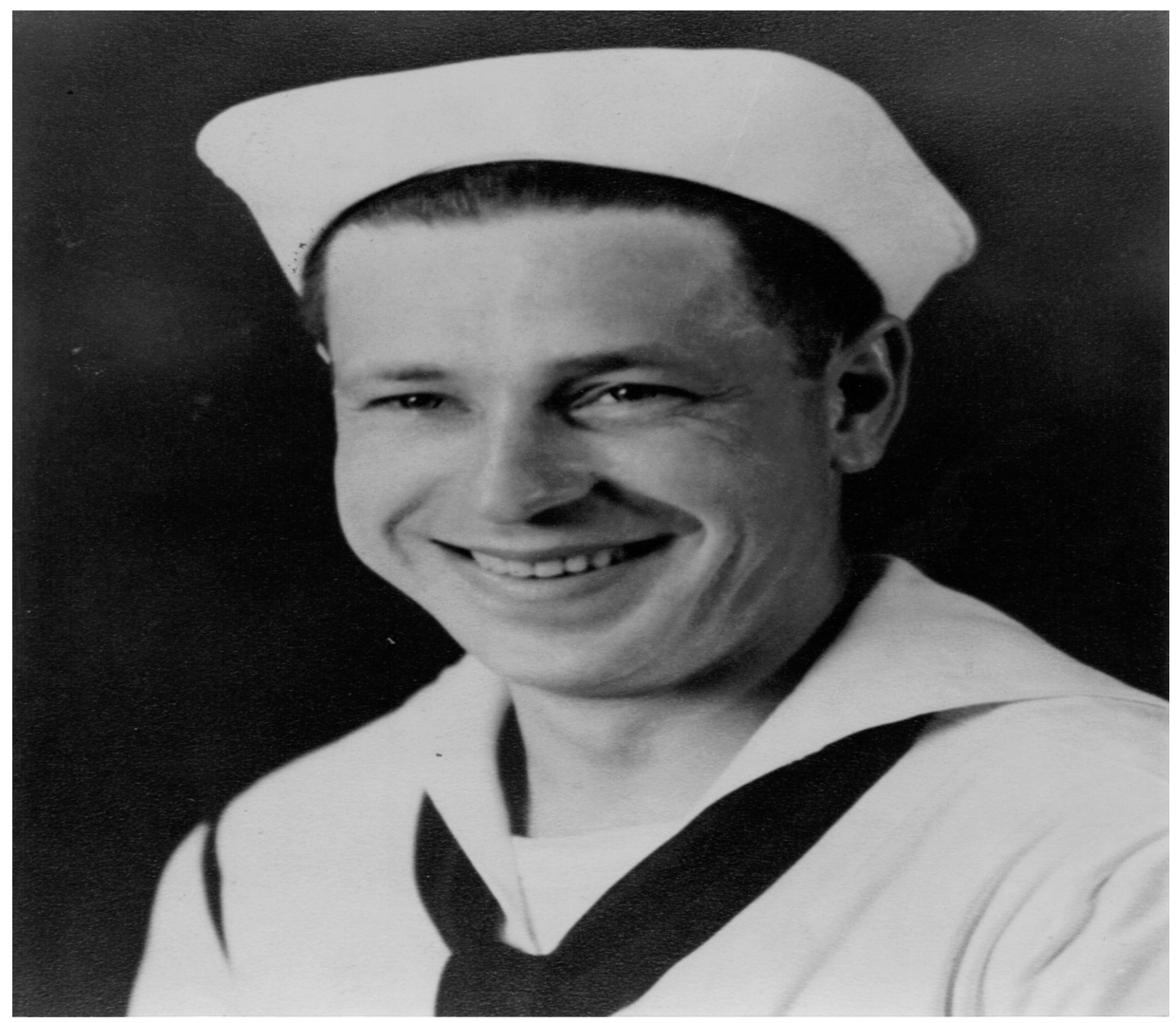

AMM2 Isadore Stessel, K-74 bombardier devoured by sharks after the battle

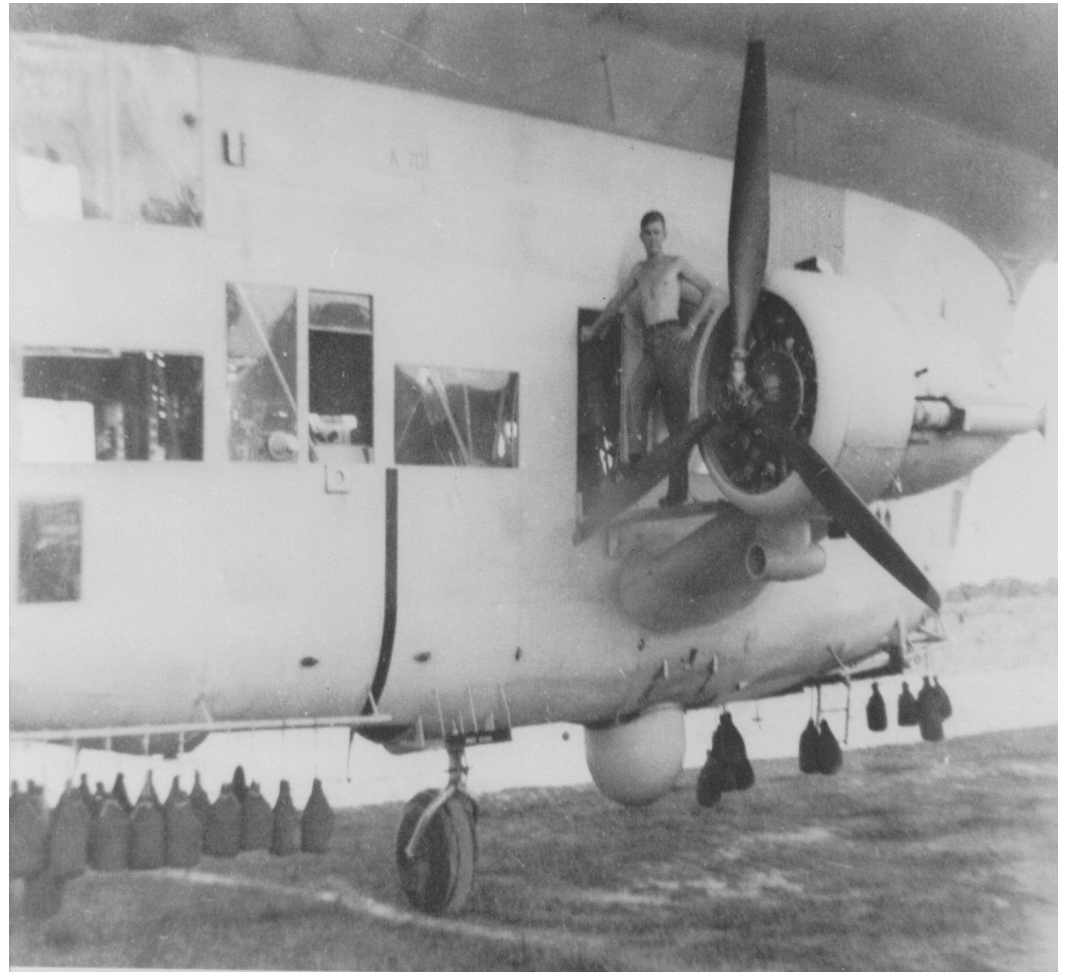

ARM3 Bob Bourne, K-74 Radioman who sent the May-Day during the combat 


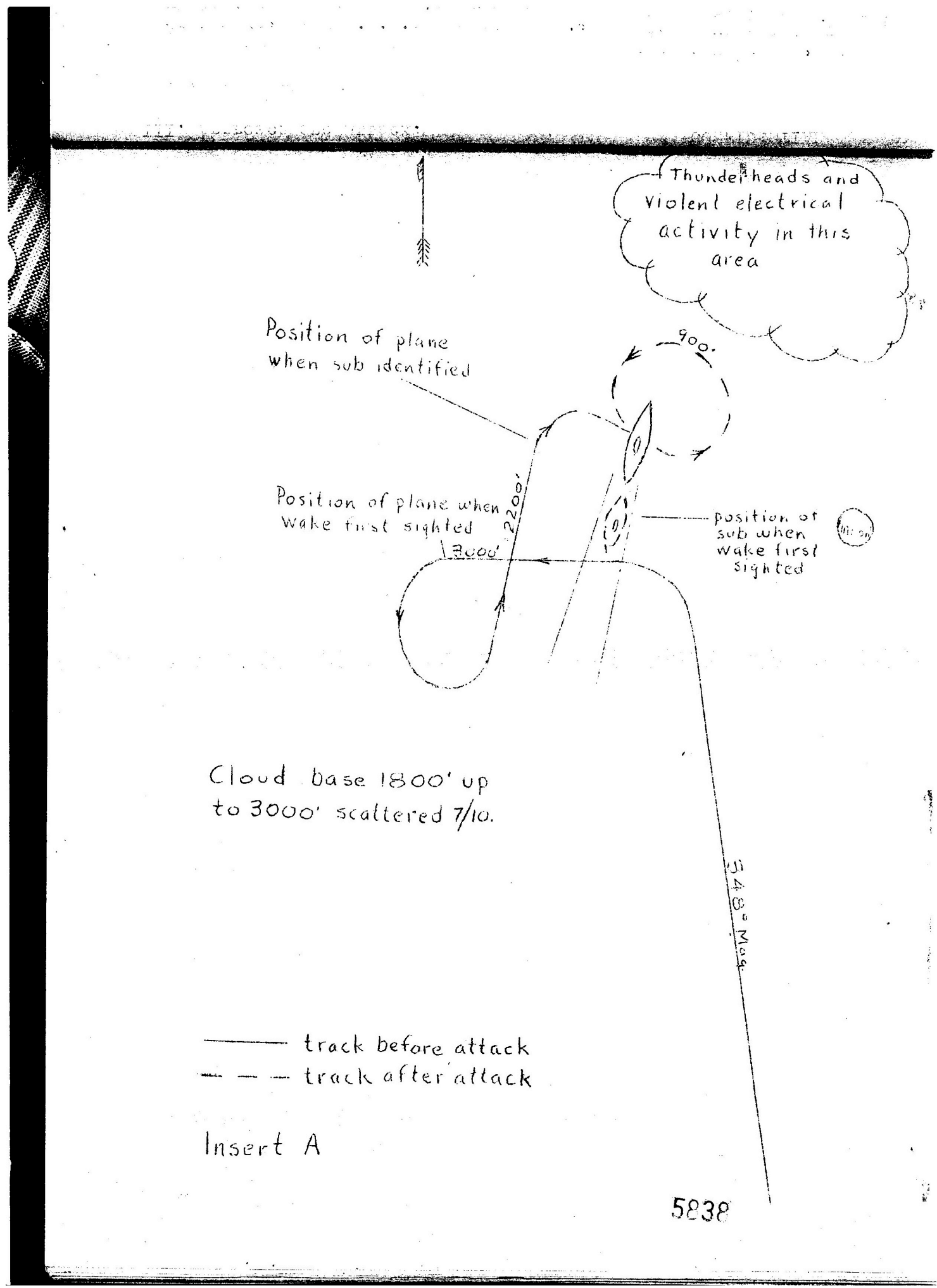

Drawing included in Action Report of PV-1 attack on U-134, 11:27 pm, 19 July 1943 


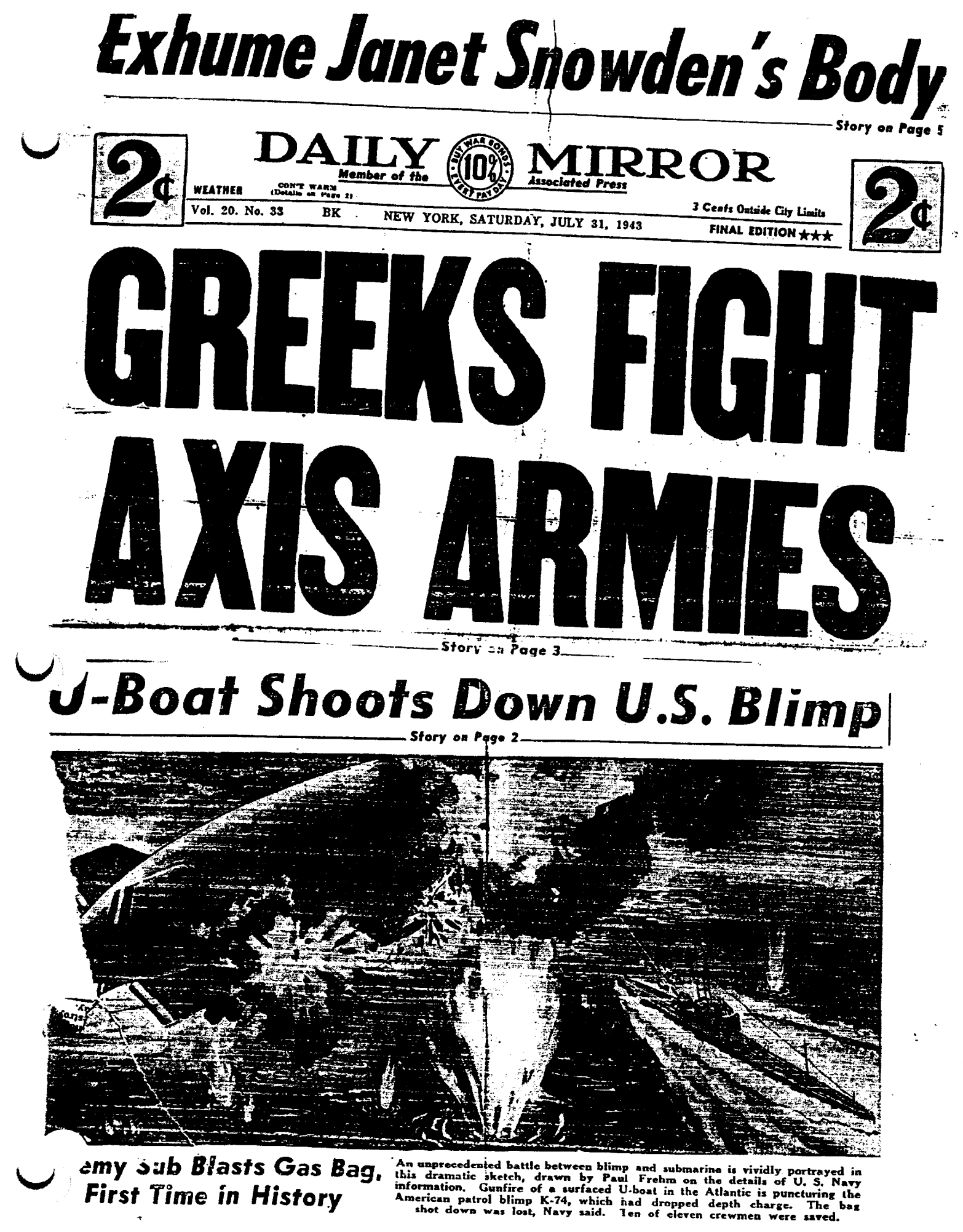

The Daily Mirror Frontpage, 31 July 1943 
hard pill to swallow to admit Hamilton's founding of its nucleus, the Revenue-Marine, was only a stop-gap in his efforts to launch a regular naval service. Some mention is due his memory for creating a military maritime service some eight years before Congress established the Navy.

Hamilton was a genius at organization, a matchless administrator, and when his sensitive and proud nature could be kept within bounds, the strongest and most valuable man in Washington's government. With prescience bevond that of his contemporaries he saw the need for a strong central government with a stable fiscal policy and he saw the means for accomplishing it. To pay the national debt and to maintain the federal government, in addition to excise taxes, foreign trade protected by income producing tariffs was a necessity. To insure this commerce, protection and encouragement must be furnished American shipping. The first practical aid he advocated was contained in the Act approved August 7,1789, providing from federal funds all expenses in the necessary support, maintenance, and repair of all lighthouses, beacons, and buoys.

The federal service charged with this duty has continued under different Departments, but is now an integral and important part of the Coast Guard. Hamilton next turned to the sea to provide protection for this country's infant commerce and to insure collection of the duties on it. He sponsored the Act approved August 4, 1790, for the "establishment and support of ten cutters" for the purpose of enforcing custom laws, and providing for a corps of forty commissioned officers.

In honor of the memory of Alexander Hamilton on the bicentennial of his birth, as called for by President Eisenhower, the Coast Guard joined in tribute to him for having founded the Revenue-Marine and the Lighthouse Service. These were built on such firm foundations that they have continued to the present day, occupying positions of increasing importance to the air and maritime commerce of this country. Hamilton's fleet with limited personnel has grown in greater proportion than has the country. Coast Guard personnel peak in World War II was over 170,000 and today the number is in excess of 30,000 ; colossal figures compared with the original authorization of forty officers and sixty men. The Service's greatest tribute can be made in continuing its progressive record in the Treasury Department in peace and in war.

\section{German Submarine Sinks U. S. Blimp}

Franz Selinger, Stuttgart-ObertürkHerm.-After crossing the Atlantic and fighting a Bermuda-based Mariner without success on either side, the German submarine $U$ 134, commanded by Kapitanleutnant Hans-

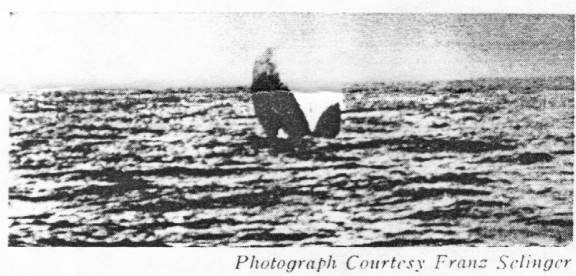

\section{SHOT DOWN BY A U-BOAT}

Gunther Brosin, was attacked on July 18, 1943 , by a patrol airship about thirty miles off the Florida keys. This blimp, later identified as the $K-74$, attempted to bomb the surfaced submarine, but once within range of the $U-134$ s flak weapons its hull and fuselage were soon riddled. With stopped engines it drifted over the submarine, but when in a bombing position the release gear jammed. Shortly afterward the $K-74$ ditched and the crew took to their rubber rafts. The $U-134$ submerged, but later surfaced and salvaged parts of the blimp. Both of the above photographs were taken from the submarine's conning tower. Fortunately these films were turned over to a refueling "milk cow" on the return passage, for Wellington bombers on August 24 sent the $U-134$ to the bottom.

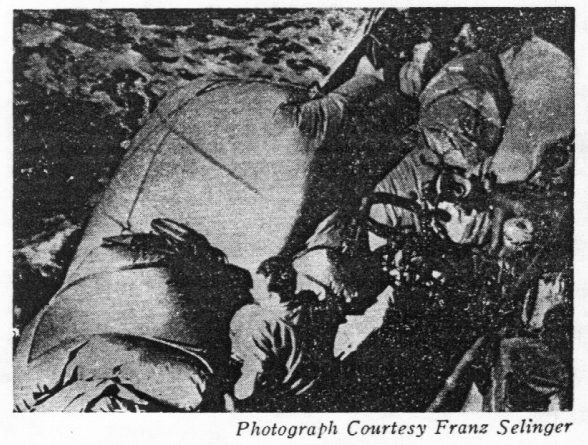

"U-134" SALVAGES THE "K-74"

\section{Nazi Hoax Photos, Navy Proceedings Journal, 1958}




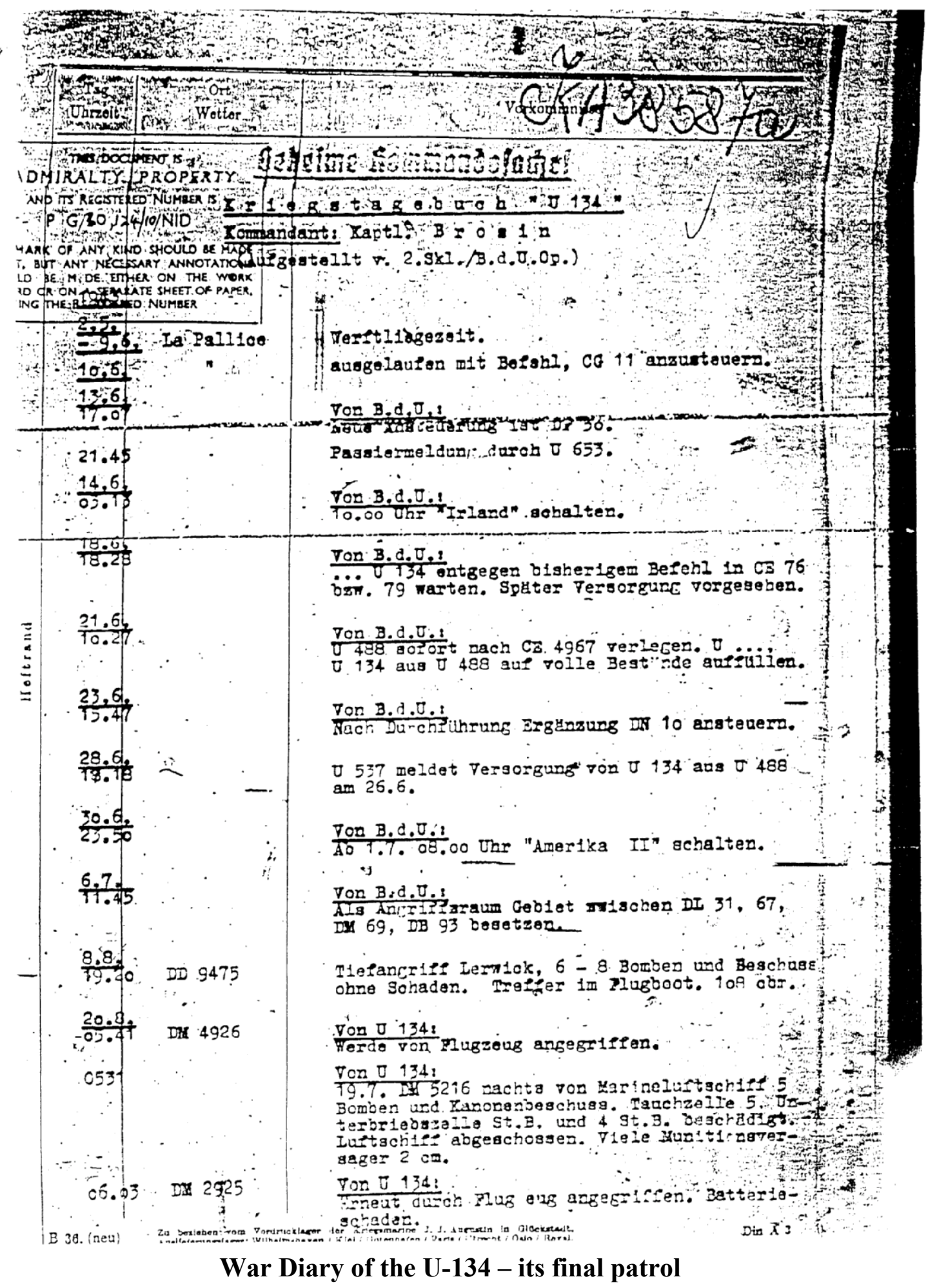




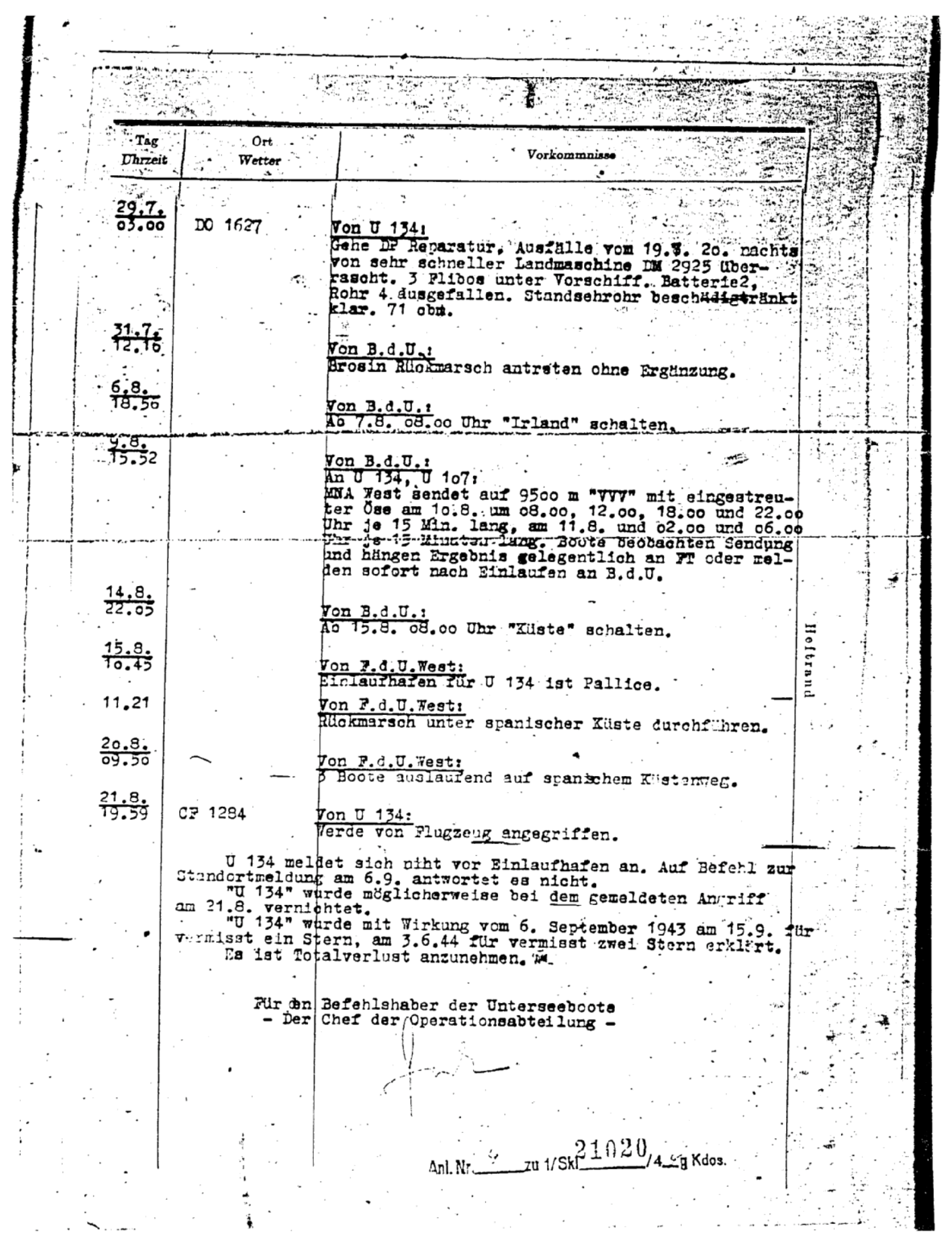

War Dairy of the U-134 - its final patrol 

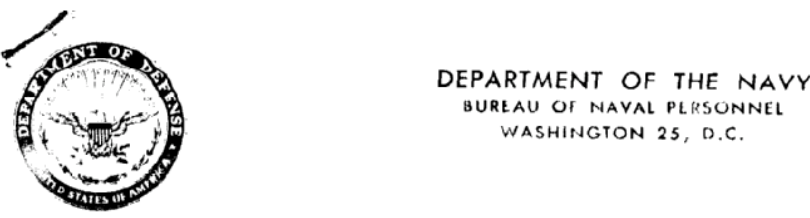

IN PEPIY REFER TO Perioniv51-ehw 5518377

From: Chief of Naval Personnel

To: BOUFNE, Robert H., ARM3, USNR

QEE 7.1960

3418 Hawthorne Road

Tampa 1l, Florida

Via: Commendant

SIXTH Naval District

Subj: Secretary of the Navy Commendation; transmittal of

Incl: (1) Citation

1. The Board for Correction of Naval Records has recently reviewed correapondence rulat1ve to the attack apndnst an uneny submarino on the right of 18-19 July 1943 by the United States A1rship K-74. As a result of this revicw, the Board recomended that you and other members of the crew be commended for your action on this occasion. The Secretary of the Navy approved the recommendation on 13 0ctober 1960.

2. The Chief of Naval Personnel takes pleasure in forwarding, with his congratulations, a Secretary of the Navy Commendation in recomition of your heroic achievement iuring the action referred to above.

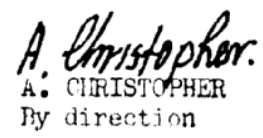

Navy Board for the Correction of Naval Records cover letter attached to the Navy Commendation Medal issued 13 Oct 1960 
The Secretary of the Navy takes pleasure in commending

ROBERT H. BOURNE

AVIATION RADIOMAN THIRD CLASS

UNITED STATES NAVAL RESERVE

for service as set forth in the following

CITATION:

"For heroic achievement on the night of 18-19 July 1943, while serving on board the United States Navy Airship $\mathrm{K}-74$, during an attack against a surfaced enemy submarine in the Straits of Florida. When the enemy submarine opened fire upon the K-74 with $20 \mathrm{~mm}$ guns, BOURNE participated in a low-altitude, machine-gun and depth-bomb attack by his craft, which inflicted damage upon the submarine and caused that vessel to disappear. The $\mathrm{K}-74$ crash-landed in the sea without injury to any of the crew. BOURNE's courage, skill, and devotion to duty in the face of hostile gunfire, were in keeping with the highest traditions of the United States Naval Service."

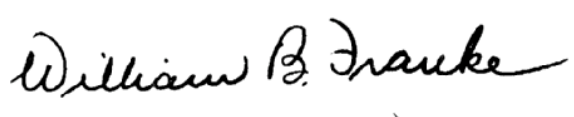

Secretary of the Navy

Citation of the Navy Commendation Medal awarded the K-74 crew in 1960 